DOE/RL-90-24

Revision 2

UC. 630

\title{
Hanford Facility Dangerous Waste Permit Application, PUREX Storage Tunnels
}

Date Published

November 1995

United States Department of Energy

Richland, Washington 99352 
TRADEMAFK DISCLAMMER

Reference herein to any specific commercial product, process, or service by trade name, trademark, manufecturer, or otherwise, does not necessarily constitute or imply its endorsement, recommendation, or favoring by the United States Government or any agency thereof or its contractors or subcontractors.

This report has been reproduced from the best available copy. Avallable in paper copy and microfiche.

Available to the U.S. Department of Energy and its contractors from

Office of Scientific and Technical information

P.O. Box 62

Oak Ridge, TN 37831

(615) 576-8401

Available to the public from the U.S. Department of Commerce National Technical Information Service

5285 Port Royal Road

Springfield, VA 22161

(703) $487-4650$

Printed in the United States of Americe

DISCLM-5.CHP (8-91) 


\section{INFORMATION RELEASE REQUEST PUBLIC DOCUMENT CHANGE/REVISION \\ (Short Form No. 1)}

1. Base Document ID Number: DOE/RL-90-24

2. Base Document Title:

HANFORD FACILITY DANGEROUS WASTE PERMIT APPLICATION, PUREX STORAGE TUNNELS

3. Change/Revision Number: PUREX Storage Tunnels Part B, Revision 2

4. Change/Revision Date: 11/22/95

5. Unclassified Category:* UC - 2000

6. Budget \& Reporting Code:* B\&R - EW 3135040

I verify this change/revision to the base document indicated above:

- Complies with the provisions of WHC-CM-3-4

- Contains no Limited-Use information

- Contains no classified or Applied Technology references

- Does not change the intent or meaning of the base document

- And, the base document itself is approved for public release.

7. Responsible Manager: R. C. BOWMAN

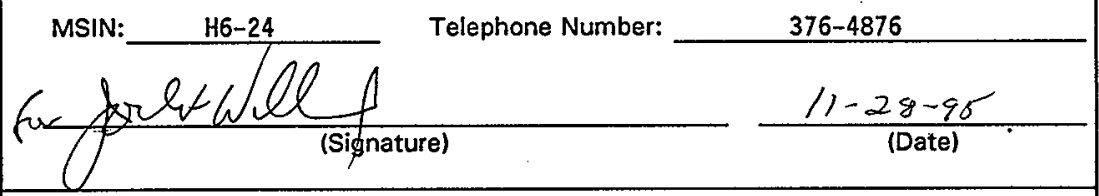

8. Information Release Administration Specialist:**

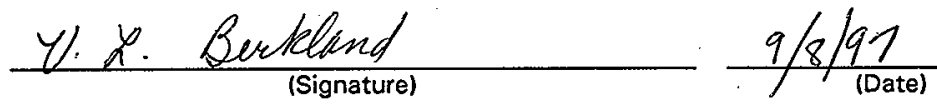

* Required only for full revisions transmitted to OSTI.

* "Required only for full revisions. 
I certify under penalty of law that this document and all attachments were prepared under my direction or supervision in accordance with a system designed to assure that qualified personnel properly gather and evaluate the information submitted. Based on my inquiry of the person or persons who manage the system, or those persons directly responsible for gathering the information, the information submitted is, to the best of my knowledge and belief, true, accurate, and complete. I am aware that there are significant penalties for submitting false information, including the possibility of fine and imprisonment for knowing violations.

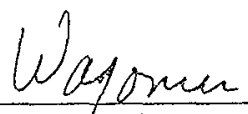

ojerer/Operator

John D. Wagoner, Manager

V.S. Department of Energy

Richland Operations office

27

28

29

30

31

32

33

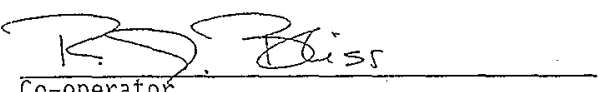

R. J. Bliss, Vice President and Manager

Transition Projects

Westinghouse Hanford Company
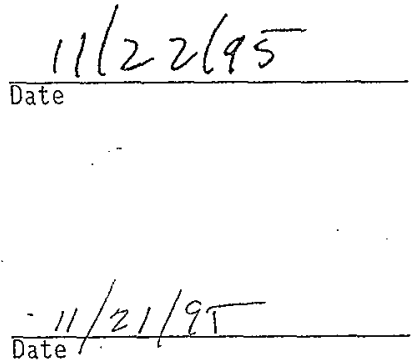
DOE/RL-90-24, Rev. 2

$.11 / 95$

\title{
THE HANFORD FACILITY DANGEROUS WASTE PERMIT APPLICATION, PUREX STORAGE TUNNELS
}

\author{
FOREWORD
}

The Hanford Facility Dangerous Waste Permit Application is considered to be a single application organized into a General Information Portion (document number DOE/RL-91-28) and a Unit-Specific Portion. The scope of the Unit-Specific Portion is 1 imited to Part $B$ permit application documentation submitted for individual, 'operating' treatment, storage, and/or disposal units, such as the PUREX Storage Tunnels (this document, DOE/RL-90-24).

Both the General Information and Unit-Specific portions of the Hanford Facility Dangerous Waste Permit Application address the content of the Part B permit application guidance prepared by the Washington State Department of Ecology (Ecology 1987 and 1995) and the U.S. Environmental Protection Agency (40 Code of Federal Regulations 270), with additional information needs defined by the Hazardous and solid Waste Amendments and revisions of Washington Administrative Code 173-303. For ease of reference, the Washington State Department of Ecology alpha-numeric section identifiers from the permit application guidance documentation (Ecology 1987 and 1995) follow, in brackets, the chapter headings and subheadings. A checklist indicating where information is contained in the PUREX Storage Tunnels permit application documentation, in relation to the Washington State Department of Ecology guidance, is located in the contents Section.

Documentation contained in the General Information Portion is broader in nature and could be used by multiple treatment, storage, and/or disposal units (e.g., the glossary provided in the General Information Portion). Wherever appropriate, the PUREX Storage Tunnels permit application documentation makes cross-reference to the General Information Portion, rather than duplicating text.

Information provided in this PUREX Storage Tunnels permit application documentation is current as of November 1995. 
DOE/RL-90-24, Rev. 2

$11 / 95$

This page intentiona17y left blank. 


\section{DOCUMENT CONTENT}

FOREWORD

METRIC CONVERSION CHART

APPLICATION CHECKLIST

1.0 PART $A[A]$

2.0 FACILITY DESCRIPTION AND GENERAL PROVISIONS [B AND E]

3.0 WASTE ANALYSIS [C]

4.0 PROCESS INFORMATION [D-1 THROUGH D-8]

5.0 GROUNDWATER MONITORING FOR LAND-BASED UNITS [D-10]

6.0 PROCEDURES TO PREVENT HAZARDS [F]

7.0 CONTINGENCY PLAN $\cdot[G]$

8.0 PERSONNEL TRAINING [H]

9.0 EXPOSURE INFORMATION REPORT

10.0 WASTE MINIMIZATION [D-9]

11.0 CLOSURE AND FINANCIAL ASSURANCE [I]

12.0 REPORTING AND RECORDKEEPING

13.0 OTHER FEDERAL AND STATE LAWS [J]

14.0 PART B CERTIFICATION [K]

15.0 REFERENCES 
DOE/RL-90-24, Rev. 2

\section{APPENDICES}

3

$42 A$ TOPOGRAPHIC MAP

5

6 3A WASTE ANALYSIS PLAN FOR PUREX STORAGE TUNNELS

7

8 4A ENGINEERING DRAWINGS

9

10 7A UNIT-SPECIFIC CONTINGENCY PLAN FOR THE 218-E-14 AND

11 218-E-15 STORAGE TUNNELS

$12^{.}$

13 8A DANGEROUS WASTE TRAINING PLAN FOR THE PUREX FACILITY. 
34

35

\section{METRIC CONVERSION CHART}

The following conversion chart is provided to the reader as a tool to aid in conversion.

Into metric units

Out of metric units

\begin{tabular}{|c|c|c|c|c|c|}
\hline If you know & $\begin{array}{c}\text { Multiply } \\
\text { by }\end{array}$ & To get & If you know & $\begin{array}{c}\text { Multiply } \\
\text { by }\end{array}$ & To get \\
\hline \multicolumn{3}{|c|}{ Length } & \multicolumn{3}{|c|}{ Length } \\
\hline inches & 25.40 & millimeters & millimeters & 0.0393 & inches \\
\hline inches & 2.54 & centimeters & centimeters & 0.393 & inches \\
\hline feet & 0.3048 & meters & meters & 3.2808 & feet \\
\hline yards & 0.914 & meters & meters & 1.09 & yards \\
\hline miles & 1.609 & kilometers & kilometers & 0.62 & miles \\
\hline \multicolumn{3}{|c|}{ Area } & \multicolumn{3}{|c|}{ Area } \\
\hline $\begin{array}{l}\text { square } \\
\text { inches }\end{array}$ & 6.4516 & $\begin{array}{l}\text { square } \\
\text { centimeters }\end{array}$ & $\begin{array}{l}\text { square } \\
\text { centimeters }\end{array}$ & 0.155 & $\begin{array}{l}\text { square } \\
\text { inches }\end{array}$ \\
\hline square feet & 0.092 & $\begin{array}{l}\text { square } \\
\text { meters }\end{array}$ & $\begin{array}{l}\text { square } \\
\text { meters }\end{array}$ & 10.7639 & $\begin{array}{l}\text { square } \\
\text { feet }\end{array}$ \\
\hline $\begin{array}{l}\text { square } \\
\text { yards }\end{array}$ & 0.836 & $\begin{array}{l}\text { square } \\
\text { meters }\end{array}$ & $\begin{array}{l}\text { square } \\
\text { meters }\end{array}$ & 1.20 & $\begin{array}{l}\text { square } \\
\text { yards }\end{array}$ \\
\hline $\begin{array}{l}\text { square } \\
\text { miles }\end{array}$ & 2.59 & $\begin{array}{l}\text { square } \\
\text { kilometers }\end{array}$ & $\begin{array}{l}\text { square } \\
\text { kilometers }\end{array}$ & 0.39 & $\begin{array}{l}\text { square } \\
\text { miles }\end{array}$ \\
\hline acres & 0.404 & hectares & hectares & 2.471 & acres \\
\hline \multicolumn{3}{|c|}{ Mass (weight) } & \multicolumn{2}{|c|}{ Mass (weight) } & $\cdot$ \\
\hline ounces & 28.35 & grams & grams & 0.0352 & ounces \\
\hline pounds & 0.453 & kjlograms & kjlograms & 2.2046 & pounds \\
\hline short ton & 0.907 & metric ton & metric ton & 1.10 & short ton \\
\hline \multicolumn{3}{|c|}{ Volume } & \multicolumn{3}{|c|}{ Volume } \\
\hline $\begin{array}{l}\text { fluid } \\
\text { ounces }\end{array}$ & 29.57 & millititers & milliliters & 0.03 & $\begin{array}{l}\text { fluid } \\
\text { ounces }\end{array}$ \\
\hline quarts & 0.95 & liters & Titers & 1.057 & quarts \\
\hline gallons & 3.79 & Titers & Titers & 0.26 & gallons \\
\hline cubic feet & 0.03 & $\begin{array}{l}\text { cubic } \\
\text { meters }\end{array}$ & $\begin{array}{l}\text { cubic } \\
\text { meters }\end{array}$ & 35.3147 & cubic feet \\
\hline cubic yards & 0.76 & $\begin{array}{l}\text { cubic } \\
\text { meters }\end{array}$ & $\begin{array}{l}\text { cubic } \\
\text { meters }\end{array}$ & 1.308 & $\begin{array}{l}\text { cubic } \\
\text { yards }\end{array}$ \\
\hline \multicolumn{3}{|c|}{ Temperature } & \multicolumn{3}{|c|}{ Temperature } \\
\hline Fahrenheit & $\begin{array}{l}\text { subtract } \\
32 \text { then } \\
\text { multiply } \\
\text { by } 5 / 9 \text { ths }\end{array}$ & Celsius & Celsius & $\begin{array}{l}\text { multiply } \\
\text { by } \\
9 / 5 \text { ths, } \\
\text { then add } \\
32\end{array}$ & Fahrenheit \\
\hline
\end{tabular}

Source: Engineering Unit Conversions, M. R. Lindeburg, PE., Second Ed., 1990, Professional Publications, Inc., Belmont, California. 
This page intentionally left blank.

: 


\section{Application Checklist}

Complete this checklist by providing the facility name and indicating where the listed material has been placed in the application. This is particularly important when the application does not closely follow the outline of the checklist and guidance.

Include the completed checklist with the Dangerous Waste Permit application. 
Facility name PUREX Storage Tunnels (DOE/RL-90-24), Rev, 2

Date Application Received

\begin{tabular}{|c|c|c|c|}
\hline \multicolumn{4}{|c|}{$\begin{array}{l}\text { State of Washington } \\
\text { Part B Permit Application Review Checklist for } \\
\text { Treatment and Storage in Tanks and Containers }\end{array}$} \\
\hline & & $\begin{array}{l}\text { Technically } \\
\text { Adequate? }\end{array}$ & Location in Application \\
\hline A. & Part A Form & & Chapter 1.0 \\
\hline B. & $\begin{array}{l}\text { Facility Description and General } \\
\text { Provisions }\end{array}$ & & Chapter 2.0 \\
\hline B-f & General Description & & 2.1 \\
\hline B-1(a) & Facility Description & & 2.1 \\
\hline$B-1(b)$ & Construction Schedule & & Not Applicable \\
\hline B-2 & Topographic Map & & 2.2 \\
\hline B-2a & General Requirements & & 2.2 \\
\hline$B-2 b$ & $\begin{array}{l}\text { Additional Requirements for Land } \\
\text { Disposal Facilities }\end{array}$ & $\begin{array}{l}\text { Not } \\
\text { Applicable }\end{array}$ & Not Applicable \\
\hline B-3 & Seismic Consideration & & Not Applicable \\
\hline B-4 & Traffic Information & & 2.3 \\
\hline C. & Waste Analysis & & Chapter 3.0 \\
\hline C-1 & $\begin{array}{l}\text { Chemical, Biological and Physical } \\
\text { Analyses }\end{array}$ & & 3.1 \\
\hline $\begin{array}{l}\text { C-1a } \\
\text { C-1b } \\
\text { C-1c }\end{array}$ & $\begin{array}{l}\text { Waste In Piles } \\
\text { Landfilled Wastes } \\
\text { Wastes Incinerated and Wastes Used in. } \\
\text { Performance Tests }\end{array}$ & $\begin{array}{l}\text { Not } \\
\text { Applicable }\end{array}$ & Not Applicable \\
\hline $\mathrm{C}-2$ & Waste Analysis Plan & & 3.2 and Appendix $3 \mathrm{~A}$ \\
\hline
\end{tabular}




\begin{tabular}{|c|c|c|c|}
\hline . & - & $\begin{array}{l}\text { Technically } \\
\text { Adequate? }\end{array}$ & Location in Application \\
\hline$C-2 a$ & $\begin{array}{l}\text { Detailed Chemical, Physical, and/or } \\
\text { Biological Analysis }\end{array}$ & & Appendix $3 \mathrm{~A}$ \\
\hline $\mathrm{C}-2 \mathrm{a}(1)$ & Parameters and Rationale & & Appendix 3A \\
\hline $\mathrm{C}-2 \mathrm{a}(2)$ & Analytical Methods & & Appendix $3 \mathrm{~A}$ \\
\hline$C-2 a(3)$ & Generator-Supplied Analyses & & Appendix 3A \\
\hline$C-2 b$ & $\begin{array}{l}\text { Additional Requirements for Wastes } \\
\text { Generated Off-site }\end{array}$ & & Appendix $3 \mathrm{~A}$ \\
\hline$C-2 b(1)$ & $\begin{array}{l}\text { Parameters and Rationale to } \\
\text { Confirm Identity of Off-site } \\
\text { Waste }\end{array}$ & . & Appendix 3A \\
\hline$C-2 b(2)$ & $\begin{array}{l}\text { Analytical Methods to Confirm } \\
\text { Identity of Off-site Waste }\end{array}$ & & Appendix $3 \mathrm{~A}$ \\
\hline$C-2 b(3)$ & $\begin{array}{l}\text { Representative Sampling of } \\
\text { Incoming Off-site Wastes }\end{array}$ & & Appendix 3A \\
\hline $\mathrm{C}-2 \mathrm{c}$ & $\begin{array}{l}\text { Methods for Collecting Samples for } \\
\text { Detailed and Confirming Analyses }\end{array}$ & & Appendix 3A \\
\hline$C-2 d$ & Frequency of Analyses & & Appendix $3 \mathrm{~A}$ \\
\hline $\mathrm{C}-3$ & Manifest System & & Appendix $3 \mathrm{~A}$ \\
\hline$C-3 a$ & Procedures for Receiving Shipments & & Appendix 3A \\
\hline $\mathrm{C}-3 \mathrm{~b}$ & Response to Significant Discrepancies & & Appendix 3A \\
\hline $\mathrm{C}-3 \mathrm{c}$ & $\begin{array}{l}\text { Provisions for Non-acceptance of } \\
\text { Shipment }\end{array}$ & & Appendix $3 \mathrm{~A}$ \\
\hline$C-3 c(1)$ & $\begin{array}{l}\text { Non-acceptance of Undamaged } \\
\text { Shipment }\end{array}$ & & Appendix 3A \\
\hline $\mathrm{C}-3 \mathrm{c}(2)$ & $\begin{array}{l}\text { Activation of Contingency Plan } \\
\text { for Damaged Shipment }\end{array}$ & & Appendix $3 \mathrm{~A}$ \\
\hline$C-4$ & Tracking System & & 3.3 \\
\hline
\end{tabular}




\begin{tabular}{|c|c|c|c|c|}
\hline & & & $\begin{array}{l}\text { Technically } \\
\text { Adequate? }\end{array}$ & Location in Application \\
\hline D. & Proc & Information & & Chapter 4.0 \\
\hline D-1 & Cont & zers & & 4.2 \\
\hline D-1a & Desc & tion of Containers & & 4.2 \\
\hline D-1b & Cont & eer Management Practices & & 4.2 \\
\hline$D-1 c$ & Cont & her Labelling & & 4.2 \\
\hline D-1d & $\begin{array}{l}\text { Cont } \\
\text { Cont }\end{array}$ & $\begin{array}{l}\text { ament Requirements for Storing } \\
\text { hers }\end{array}$ & & 4.2 \\
\hline D-1d(1) & & $\begin{array}{l}\text { Secondary Containment System } \\
\text { Design }\end{array}$ & & 4.2 \\
\hline$D-1 d(1)$ & (a) & System Design & & $4.2^{\circ}$ \\
\hline$D-1 d(1)$ & (b) & Structural Integrity of Base & & 4.2 \\
\hline $\mathrm{D}-1 \mathrm{~d}(1)$ & $(\mathrm{c})$ & Containment System Capacity & . & 4.2 \\
\hline D-1d(1) & $(d)$ & Control of Run-on & & 4.2 \\
\hline$D-1 d(2)$ & . & $\begin{array}{l}\text { Removal of Liquids from } \\
\text { Containment System }\end{array}$ & & 4.2 \\
\hline D-1e & $\begin{array}{l}\text { Dem } \\
\text { Requ } \\
\text { Cont } \\
\text { Exhi } \\
\text { Was } \\
\text { F02 }\end{array}$ & $\begin{array}{l}\text { stration that Containment Is Not } \\
\text { ed Because Containers Do Not } \\
\text { Free Liquids, Wastes That } \\
\text { Ignitability or Reactivity, or } \\
\text { Designated F020-023, F026, or }\end{array}$ & & 4.2 \\
\hline D-1f & $\begin{array}{l}\text { Prev } \\
\text { Reac } \\
\text { Cont }\end{array}$ & $\begin{array}{l}\text { tion of Reaction of Ignitable, } \\
\text { e, and Incompatible Wastes in } \\
\text { ners }\end{array}$ & & 4.2 \\
\hline$D-1 f(1)$ & & $\begin{array}{l}\text { Management of Certain Reactive } \\
\text { Wastes in Containers }\end{array}$ & & 4.2 \\
\hline $\mathrm{D}-1 \mathrm{f}(2)$ & & $\begin{array}{l}\text { Management of Ignitable and } \\
\text { Certain Other Reactive Wastes in } \\
\text { Containers }\end{array}$ & & 4.2 \\
\hline
\end{tabular}




\begin{tabular}{|c|c|c|c|}
\hline & & $\begin{array}{l}\text { Technically } \\
\text { Adequate? }\end{array}$ & Location in Application \\
\hline$D-1 f(3)$ & $\begin{array}{l}\text { Design of Areas to Manage } \\
\text { Incompatible Wastes }\end{array}$ & & 4.2 \\
\hline D-2 & Tank Systems & & Not Applicable \\
\hline $\begin{array}{ll}\mathrm{D}-2 \mathrm{a} & \mathrm{D} \\
& \mathrm{T} \\
\end{array}$ & $\begin{array}{l}\text { Design, Installation and Assessment of } \\
\text { Tanks Systems }\end{array}$ & & Not Applicable \\
\hline D-2a(1) & Design Requirements & & Not Applicable \\
\hline D-2a(2) & Integrity Assessments & & Not Applicable \\
\hline $\mathrm{D}-2 \mathrm{a}(3)$ & $\begin{array}{l}\text { Additional Requirements for } \\
\text { Existing. Tanks }\end{array}$ & & Not Applicable \\
\hline $\mathrm{D}-2 \mathrm{a}(4)$ & $\begin{array}{l}\text { Additional Requirements for } \\
\text { New Tanks }\end{array}$ & & Not Applicable \\
\hline $\mathrm{D}-2 \mathrm{a}(5)$ & $\begin{array}{l}\text { Additional Requirements for } \\
\text { New On-ground or Underground } \\
\text { Tanks }\end{array}$ & & Not Applicable \\
\hline$D-2 b$ & $\begin{array}{l}\text { Secondary Containment and Release } \\
\text { Detection for Tank Systems }\end{array}$ & & Not Applicable \\
\hline$D-2 b(1)$ & $\begin{array}{l}\text { Requirements for All Tank } \\
\text { Systems }\end{array}$ & & Not Applicable \\
\hline$D-2 b(2)$ & $\begin{array}{l}\text { Additional Requirements for } \\
\text { Specific Types of Systems }\end{array}$ & & Not Applicable \\
\hline$D-2 b(2)(a$ & Vault Systems & & Not Applicable \\
\hline$D-2 b(2)(b$ & Double-walled Tanks & & Not Applicable \\
\hline$D-2 b(2)(c$ & Ancillary Equipment & & Not Applicable \\
\hline $\mathrm{D}-2 \mathrm{c}$ & $\begin{array}{l}\text { Variances from Secondary Containment } \\
\text { Requirements }\end{array}$ & & Not Applicable \\
\hline$D-2 d$ & Tank Management Practices & & Not Applicable \\
\hline$D-2 e$ & Labels or Signs & & Not Applicable \\
\hline
\end{tabular}




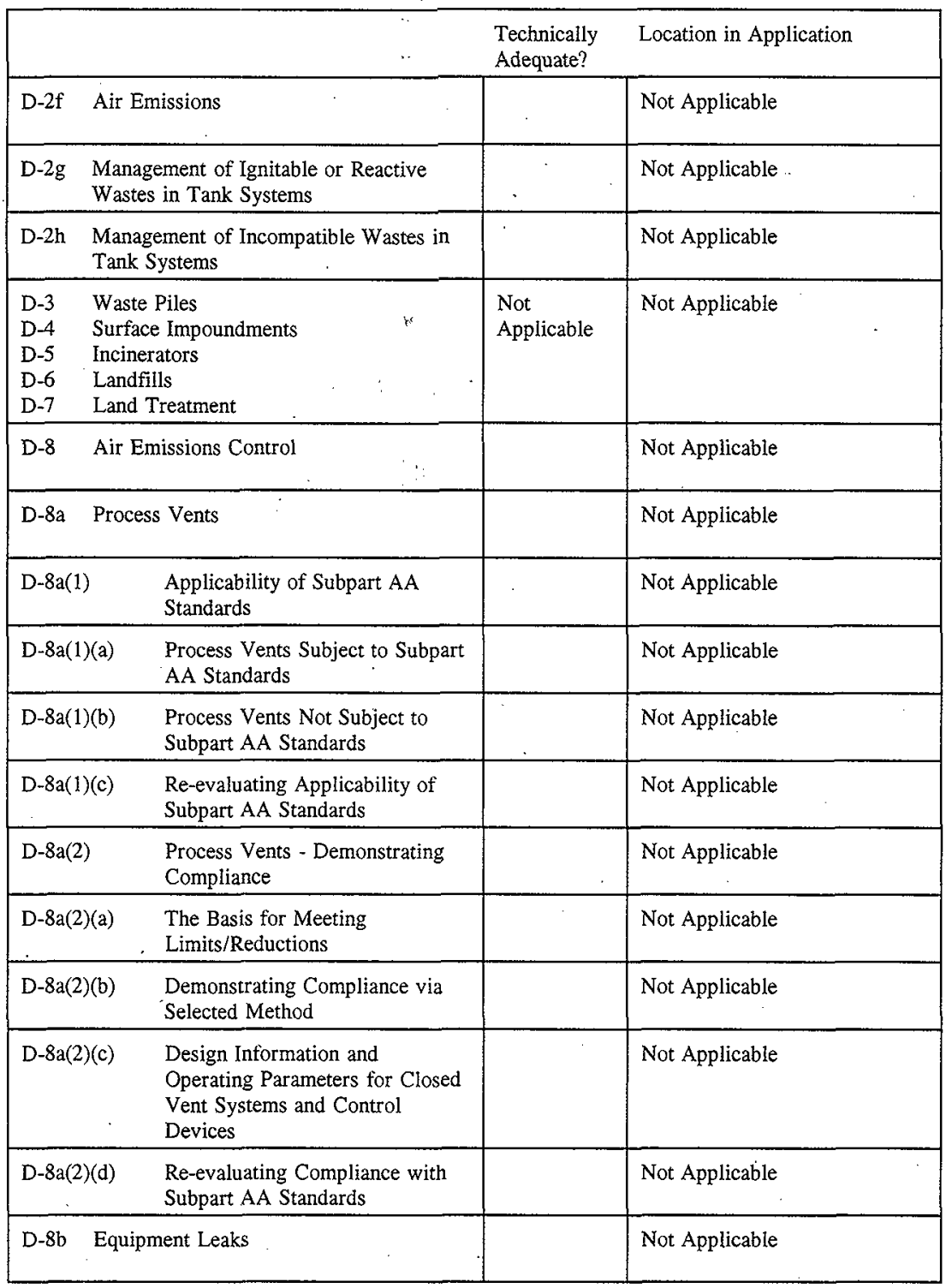




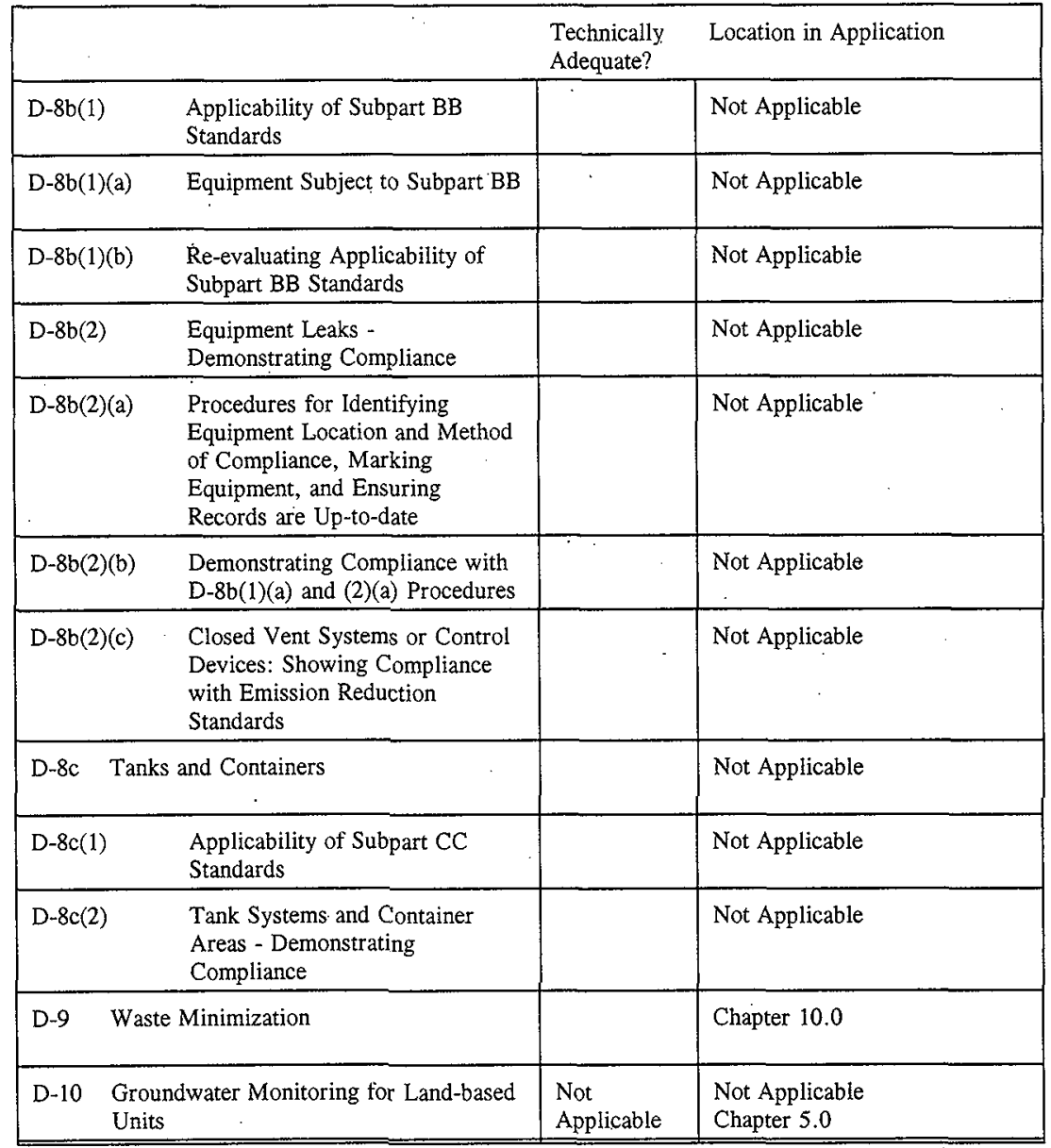




\begin{tabular}{|c|c|c|c|}
\hline & & $\begin{array}{l}\text { Technically } \\
\text { Adequate? }\end{array}$ & Location in Application \\
\hline E. & $\begin{array}{l}\text { Releases from Solid Waste } \\
\text { Management Units }\end{array}$ & & Chapter 2.0 \\
\hline E-1 & $\begin{array}{l}\text { Solid Waste Management Units and } \\
\text { Known and Suspected Releases of } \\
\text { Dangerous Wastes or Constituents }\end{array}$ & · & 2.4 \\
\hline E-1a & Solid Waste Management Units & & 2.4 \\
\hline E-1b & Releases & & 2.4 \\
\hline E-2 & Corrective Actions Implemented & & 2.4 \\
\hline F. & Procedures to Prevent Hazards & & Chapter 6.0 \\
\hline F-1 & Security & & 6.1 \\
\hline F-1a & Security Procedures and Equipment & & 6.1 \\
\hline F-1b & Waiver & & 6.1 .2 \\
\hline $\mathrm{F}-2$ & Inspection Plan & & 6.2 \\
\hline$F-2 a$ & General Inspection Requirements & & 6.2 \\
\hline $\mathrm{F}-2 \mathrm{~b}$ & Inspection Log & & 6.2 \\
\hline $\mathrm{F}-2 \mathrm{c}$ & $\begin{array}{l}\text { Schedule for Remedial Action for } \\
\text { Problems Revealed }\end{array}$ & & 6.2 \\
\hline$F-2 d$ & $\begin{array}{l}\text { Specific Process or Waste Type } \\
\text { Inspection Requirements }\end{array}$ & & 6.2 \\
\hline \multicolumn{2}{|r|}{ Container Inspections } & & Not Applicable \\
\hline $\mathrm{F}-2 \mathrm{~d}(2)$ & $\begin{array}{l}\text { Tank System Inspections and } \\
\text { Corrective Actions }\end{array}$ & & Not Applicable \\
\hline$F-2 d(2)(a)$ & Tank System Inspections & & Not Applicable \\
\hline$F-2 d(2)(b)$ & $\begin{array}{l}\text { Tank Systems - Corrective } \\
\text { Actions }\end{array}$ & & Not Applicable \\
\hline
\end{tabular}




\begin{tabular}{|l|l|l|}
\hline \multicolumn{2}{|c|}{ Technically } \\
Adequate?
\end{tabular}




\begin{tabular}{|l|l|l|}
\hline \multicolumn{2}{|c|}{$\begin{array}{l}\text { Technically } \\
\text { Adequate? }\end{array}$} \\
\hline G. $\quad$ Contingency Plan & & Chapter 7.0 \\
\hline G-1 General Information & & Appendix 7A \\
\hline G-2 Emergency Coordinators & & Appendix 7A \\
\hline G-3 Circumstances Prompting Implementation & & Appendix 7A \\
\hline G-4 Emergency Response Procedures & & Appendix 7A \\
\hline G-4a $\quad$ Notification & & Appendix 7A \\
\hline G-4b $\quad$ Identification of Dangerous Materials & & Appendix 7A \\
\hline G-4c $\quad$ Hazard Assessment and Report & & Appendix 7A \\
\hline G-4d $\quad \begin{array}{l}\text { Prevention of Recurrence or Spread of } \\
\text { Fires, Explosions, or Releases }\end{array}$ & & Appendix 7A \\
\hline G-4f $\quad$ Post-Emergency Actions & & Appendix 7A \\
\hline G-5 $\quad$ Emergency Equipment & & Appendix 7A \\
\hline G-6 $\quad$ Coordination Agreements & & Appendix 7A \\
\hline G-7 $\quad$ Evacuation Plan & & Appendix 7A \\
\hline G-8 & & Appendix 7A \\
\hline G-8(1) General Requirements & & Not Applicable \\
\hline G-8(2) Requirements for Tank Systems & & \\
\hline \hline
\end{tabular}




\begin{tabular}{|l|l|l|}
\hline \multicolumn{2}{|c|}{ Technically } \\
Adequate?
\end{tabular}




\begin{tabular}{|c|c|c|c|}
\hline & & $\begin{array}{l}\text { Technically } \\
\text { Adequate? }\end{array}$ & Location in Application \\
\hline $\mathrm{I}-1 \mathrm{~g}$ & Extension for Closure Time & & Chapter 11.0 \\
\hline I-1h & Closure Cost Estimate & & Chapter 11.0 \\
\hline $\mathrm{I}-1 \mathrm{i}$ & $\begin{array}{l}\text { Financial Assurance Mechanism for } \\
\text { Closure }\end{array}$ & & Not Applicable \\
\hline $1-2$ & $\begin{array}{l}\text { Notice in Deed of Already Closed } \\
\text { Disposal Units }\end{array}$ & & Not Applicable \\
\hline $1-3$ & Post-Closure Plan & & Not Applicable \\
\hline $1-4$ & Liability Requirements & & Not Applicable \\
\hline$I-4 a$ & $\begin{array}{l}\text { Coverage for Sudden Accidental } \\
\text { Occurrences }\end{array}$ & & Not Ápplicable \\
\hline $\mathrm{I}-4 \mathrm{~b}$ & $\begin{array}{l}\text { Coverage for Nonsudden Accidentat } \\
\text { Occurrences }\end{array}$ & & Not Applicable \\
\hline $1-4 c$ & Request for Variance & & Not Applicable \\
\hline J. & Other Federal and State Laws & & Chapter 13.0 \\
\hline к. & Part B Certification & & Chapter 14.0 \\
\hline
\end{tabular}




\section{CONTENTS}

2

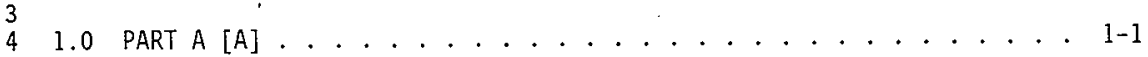


DOE/RL-90-24, Rev. 2

$11 / 95$

1
2
3
4
5

This page intentionally left blank. 


\subsection{PART A [A]}

The original Part A, Form 3, Reviston 0 , for the PUREX (piutonium-uranium extraction) Storage Tunnels was submitted in November 1987 . A revised Part A, Form 3., Revision 1, was submitted September 1990.

The Part A, Form 3, Revision 1, was submitted to redesignate the PUREX Storage Tunnels as a miscellaneous unit. Additional7y, dangerous waste code D001 [Washington Administrative Code (WAC) 173-303-090(5)] was added to address the ignitable characteristic of the silver nitrate stored in Tunnel Number 2. The estimated annual quantities of waste also were modified to represent the maximum quantity of waste placed in the PUREX Storage Tunnels in any given year since initial operation.

The Part A, Form 3, Revision 2, was submitted in December 1994. This revision was prepared to add Dangerous Waste Numbers D006 (cadmium), D007 (chromium), WT01 (state-onTy, toxic, extremely hazardous waste), and WC02 (state-only, carcinogenic, dangerous waste) to existing Process Code S05 (storage-miscellaneous). Also, State-only Dangerous Waste Numbers WT02 (state-only, toxic, dangerous waste) and WP01 (state-only, persistent, extremely hazardous waste) were added to Process Code S05. State-oniy Dangerous Waste Number WTOI was removed from Dangerous Waste Number D008 (1ead) in accordance with WAC 173-303-100.

The Part A, Form 3, Revision 3, included in this permit application documentation consists of five pages, three figures, and one photograph, and was prepared to add dangerous waste numbers D005 (barium), D010 (selenium), and WTO2 (state-only, toxic, dangerous waste for 1ight mineral 0i1) to process code (SO5). State-only dangerous waste numbers WT02 (state-only, toxic, dangerous waste) and WPO1 (state-only, persistent, extremely hazardous waste) were removed. 
DOE/RL-90-24, Rev. 2

$11 / 95$

This page intentionally left blank. 
Please print or type in the unshaded areas only

(fill-in areas are spaced for efite type, i.e., 12 character/inch).

\begin{tabular}{|c|c|c|c|c|c|c|c|c|}
\hline & \multirow{2}{*}{\multicolumn{2}{|c|}{ DANGEROUS WASTE PERMIT APPLICATION }} & \multicolumn{6}{|c|}{ 1. EPA/STATE I.D. NUMBER } \\
\hline & & & \begin{tabular}{|l|l|l|l|}
$W$ & $A$ & 7 & 8 \\
\end{tabular} & \begin{tabular}{|l|l|}
8 & 9 \\
\end{tabular} & 1010 & 01 & 8 : & $6 \mid 7$ \\
\hline \multicolumn{9}{|c|}{ FOR OFFICIAL, USE ONLY } \\
\hline $\begin{array}{l}\text { APPUCATION } \\
\text { APPROVED }\end{array}$ & $\begin{array}{l}\text { DATERECEIVED } \\
\text { (mo. day \& } y \text {, }\end{array}$ & COMMENTS & & & & & & \\
\hline
\end{tabular}

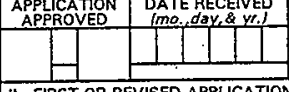

II. FIRST OR REVISED APPLICATION

Place an " $\mathrm{X}$ " in the appropriate box in A or B below (mark one box only) to indicate whather this is tho first application you are submitting for your facility or a revised Placo an ' $X$ in tho approp first application and you already know your 'facility's EPA/STATE I.D. Number, or if this is a revised application, enter your facility's EPA/STATE 1.D. Number in Section l abovo.

A. FIRST APPLICATION (place an " $X$ " below and plovide the appropriate datel $\square$ 1. EXISTING FACILITY (See instructions for definition of "existing" 1seility.

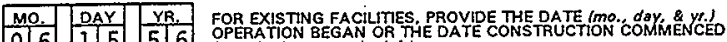

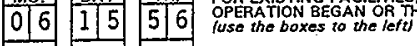

B. REVISED APPLICATION (p/ace an " $\chi^{*}$ below and complete Section / abovel

X] i. FACHLITY HAS AN INTERIM STATUS PERMIT

2. NEW FACILITY (COMpleto item below)

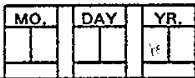

FOR NEW FACILITIES, PROVIDE THE DATE, IMON daY \& yr' OPE EXPECTED TO BEGIN

2. FACILITY HAS A FINAL PERMM

111. PROCESSES - CODES ANO CAPACITIES

A. PROCESS CODE - Enter the code from the list of process codes below that best describes each process to be used at the facility. Ten lines are provided for entering codos. If more lines aro needed, enter the code(s) in the space provided. If a process will be used that is not induded in the list of codes below, then doscribe the process fincluding its design capacity) in the space provided on the (Section II/C).

B. PROCESS DESIGN CAPACIT - Fot each code entered in column A enter the capacity of the process.

1. AMOUNT - Enter the amount.

2. UNIT OF MEASURE - For each amount entered in column B(1), onter the code from the list of unit measuro codes below that describes the unit of measure used. Only the unite of messure that are listed bolow should be used.

$\begin{array}{ccc} & \text { PRO- } & \text { APPROPRIATE UNIS OF } \\ \text { MEASUAEFOR PROCESS }\end{array}$

rago:

ONTAINER (barrel, drum, otc) WANKTE PILE

SURFACE IMPOUNDMENT

Disposs:

INJECTIÖN WELL

LANDFILL

SO1 GALLONS OR LITERS

$\mathrm{SO} 2$ GALLONS OR LITERS

SO3 CUBIC YARDS OR

SO4 GALLONS OR LITERS

DgO GALLONS OR LITERS

DBI ACRE-FEET ithe volume that would cover one acre to a depth of one foov

OR HECTARE.METER

$\mathrm{DB2}$ ACRES OR HECTARES

D83 GALLONS PER DAY OR

D84 GALLONS OR LITERS

LAND APPLICATION

SURFACE IMPOUNDMENT UNIT OF MEASURE

UNIT OF MEASURE

CODE

GALLONS . . . . . . . . . . . G

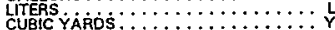

CUBIC YARDS $\ldots \ldots \ldots \ldots \ldots \ldots \ldots$

GALLONS PER DAY $\ldots \ldots \ldots \ldots \ldots \ldots$ u
EXAMPLE FOR COMPLETING SECTION IIt (shown in line numbers $X-1$ and $X-2$ belowl: A facility has two storage tanks, one tank can

OTHER (Use for physical, chemical, TO4 hermal or biological troatment processes not occurring in tanks. surface impoundments or incinerators. Describe the procossor in

\section{Treatment:}

TANK

SURFACE IMPOUNDMENT INCINERATOR

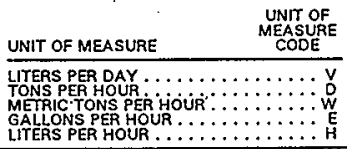
DESIGN CAPACITY
PRO- APPROPRIATE UNITS OF CESS MEASURE FOR PROCESS

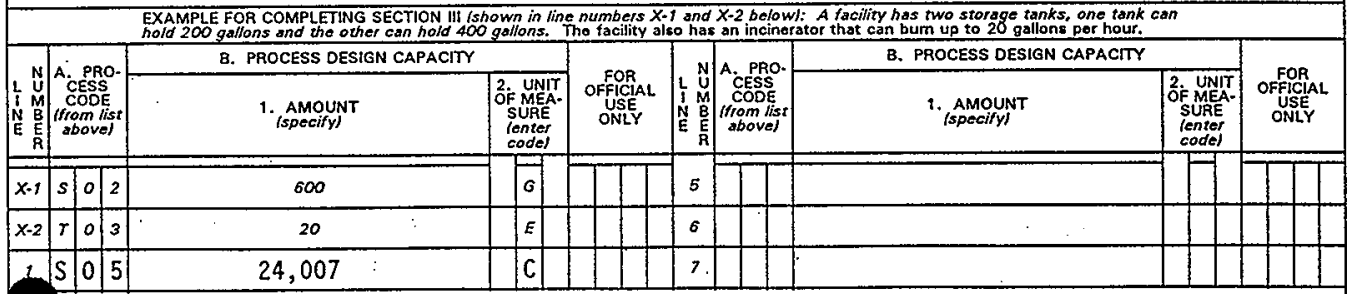

* Process Code SO5 is being used to designate the PUREX Storage Tunnels as a "Miscellaneous Unit" per 40 CFR 264, Subpart $X$.

\section{4}


Continued from the front.

OCESSES (continuad)

CE FOR ADDITIONAL PROCESS COOES OR FOR DESCRIBING OTHER PROCESS (GOdO "TO4"). FOR EACH PROCESS ENTERED HERE INCLUDE DESIGN CAPACITY.

\section{$\underline{\text { s05 }}$}

The PUREX Storage Tunnels are a miscellaneous unit (S05) used for storage of mixed waste subject to the requirements of 40 CFR 264, Subpart $X$. The two turnels are designed to store discarded equipment. Since being placed into service, mixed waste has been stored in the tunnels on railcars. Not all material stored in the tunnels contains mixed waste.

The construction of Tunnel 1 was completed in 1956. The tunnel is approximately 5.8 meters (19 feet) wide by 6.7 meters (22 feet) high by 107 meters ( 350 feet) long and provides storage space for eight railcars. Between June 1960 and January 1965, all eight railcar positions were filted and the tunnel was subsequentily sealed. The combined volume of the equipment stored in Tunnel 1 is approximately 596 cubic meters (780 cubic yards). The maximum process design capacity for storage in runnel 1 is approximately 4,129 cubic meters $(5,400$ cubic yards).

The construction of runnel 2 was completed in 1964. Tunnel 2 is approximately 5.8 meters (19 feet) wide by 6.7 meters (22 feet) high by 512 meters (1,680 feet) long and provides storage space for 40 railcars. The first railcar was placed in Tunnel 2 in December 1967 and as of June 1995, 21 railcars have been placed in the tumnel. The combined volume of equipment stored on the 21 railcars presently in Iunnel 2 is approximately 1,797 cubjc meters $(2,350$ cubic yards). The maximum process design capacity for storage in Iunnet 2 is approximately 19,878 cubic meters $(26,000$ cubic yards).

IV. DESCRIPTION OF DANGEROUS WASTES

A. DANGEROUS WASTE NUM8ER - Enter the four thigit number from Chapter 173-303 WAC for edch listed dangerous waste vou will handle, If you handle dangeraus wastos which are not listed in Chapter 173-303 WAC. enter the tour digit number(s) that doseribes the charactoristics and/or the toxic condaminants of those dangerous wastes. B. ESTIMATED ANNUAL QUANTITY - For each listed waste entered in column A ostimate the quantity of that waste that will be handied on an annual basis. possess that chasacteristic or conteminant.

c. UNIT OF MEASURE - For ach quantity enterod in column B enter the unit of moasure code. Units of moasure which must bo used ond the appropriate codes aro:

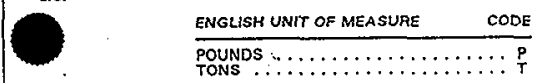

$\frac{\text { METRIC UNIT OF MEASURE }}{\text { KILOGRAMS } \ldots \ldots \ldots \ldots \ldots \ldots \ldots \ldots \ldots}$

If facility records use any other unit of measure tor quantity, the units of measure must be converted into one of the required units of measure taking into account the approprato donsity or specific gravity of the wasto.

D. PROCESSES

1. PROCESS CODES:

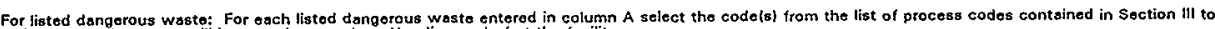
indicate how the wasto will be stored. troated. and/or disposed of at the facility,

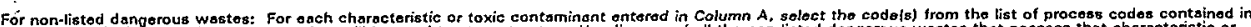

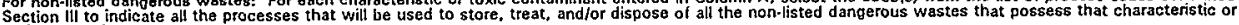
toxic contaminant.

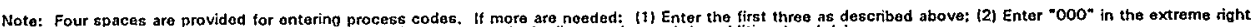
Note: Four spaces are provided for ontering process codes. If more are noeded: (1) Enter the first three as dese

2. PROCESS DESCRIPTION: If a cade is not listed for a process that will be used, describe the process in the space provided on the form.

NOTE: DANGEROUS WASTES DESCRIBED BY MORE THAN ONE DANGEROUS WASTE NUMBER - Dangerous wastes that can be described by more than one WAste Numbor shall be dercribed on the form as follows:

1. Select one of the Dangerous Waste Numbers and enter it in column A. On the same line complete columns 8 , C, and D by estimating the total annual quantity of the waste and deseribing all the processes to bo used to tieat, store, ond/or dispose of the wasto.

2. In column $A$ of the next fine enter the other Oangerous Waste Number that can be used to describe the waste. In column D(2) on that line entes "included with abovo and mako no other ontrios on that line.

3. Repent step 2 for each other Dangerous Waste Number that can be used to describe the dangerous waste.

EXAMPLE FOR COMPLETING SECTION IV (shown in lino numbors $X-1, X-2, X-3$, and $X-4$ bolowi - A faeility will treat and dispose of an estimatod 900 pounde por yoar of chrome shavings from leather tanning and finishing operation. In addition, the facility will treat and dispose of three non-listed wastes. Two wastes are corrosive

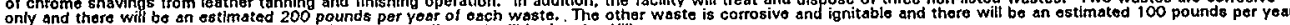
of that waste. Treatment will be in an incinorator and disposal will be in a landfill.

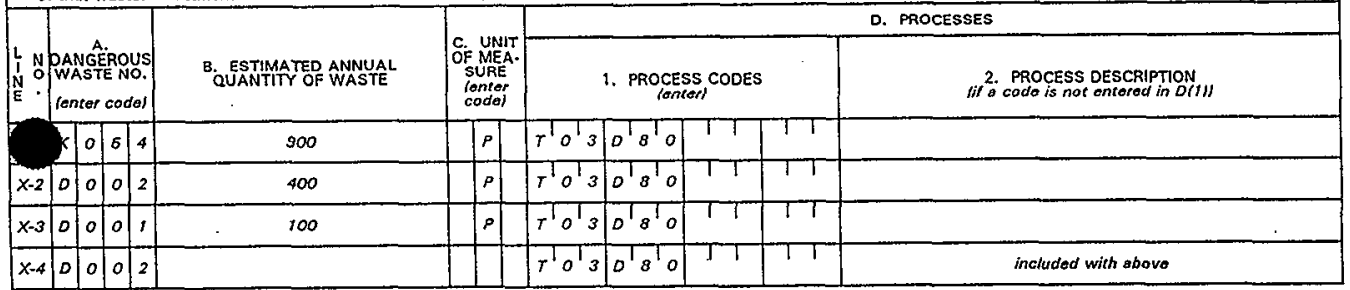


PUREX Storage Tunnels

Rev. 3, 08/21/95, Page 3 of 9

Continued from pane 2

OTE: Photocopy this poge before completing th you havo more then 26 westas to list.

NUMBER lantarad from pogo if

\begin{tabular}{|l|l|l|l|l|l|l|l|l|l|l|l|}
\hline$W$ & $A$ & 7 & $B$ & 9 & 0 & 0 & 0 & 8 & 9 & 6 & 7 \\
\hline
\end{tabular}

IV. DESCRIPTION OF DANGEROUS WASTES (continued)

\begin{tabular}{|c|c|c|c|c|c|c|c|}
\hline \multirow{2}{*}{ 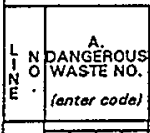 } & \multirow[b]{2}{*}{ 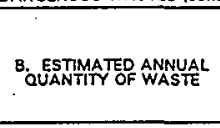 } & \multirow[b]{2}{*}{ 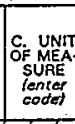 } & \multicolumn{5}{|r|}{ D. PROCESSES } \\
\hline & & & & PROCE: & 5 coots & & 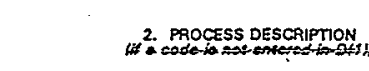 \\
\hline 1010105 & $454^{*}>0$ & $\mathrm{k}$ & 505 & $T$ & Tा & $\pi$ & Storace - Miscellaneous \\
\hline 2010106 & $454^{\star}$ & & 1 & $T$ & $T$ & $T$ & \\
\hline $3|4| C|0| 2$ & & II & TT & IT & $T 1$ & $T$ & is \\
\hline \begin{tabular}{l|l|l|l|}
4 & WT \\
\end{tabular} & & & Tा & TT & TT & $\pi$ & \\
\hline 50.01017 & $454^{\star}$ & & $T$ & ras & " & 1 & \\
\hline${ }^{8}|0| 0|0| 8$ & $2,722^{\star}$ & & 1 & ( & 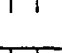 & ( & \\
\hline 7010019 & $45^{*}$ & III & T & 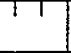 & 1 & 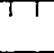 & \\
\hline 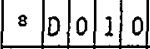 & $454^{*}$ & & 11 & $\pi$ & $\pi$ & 11 & \\
\hline 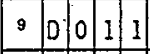 & $680^{*}$ & & $T T$ & TT & $\pi$ & 11 & \\
\hline 0.010 .1 & & 11 & 19 & & Tit & & $\downarrow$ \\
\hline$\sqrt{\pi} 02$ & $454^{*}$ & |y & $\psi$ & TT & $T$ & 1 & Inlcuded With Above \\
\hline & & & & $T$ & $T$ & T & \\
\hline
\end{tabular}

* The estimated annual quantity of waste listed above represent the maximum quantity of waste placed in either tunnel in a given year.

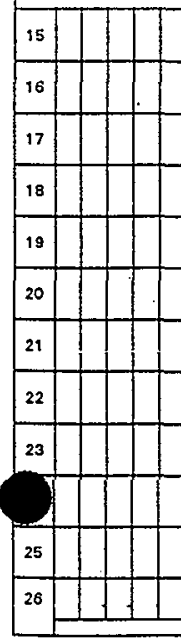

ECL $30-271$ - ECY 030-31 Form 3 
Continued from the front.

SCRIPTION OF DANGEROUS WASTES (continued)

THIS SPACE TO LIST ADDITIONAL PROCESS CODES FROM SECTION DIII ON PAGE 3.

The waste stored in the tunnels includes barium (D005), chromium (D007), cadmium (D006), lead (D008), mercury (D009), selenium (D010), silver (D011), and light mineral oil contained in oil absorption material (WTO2). The silver is predominately in the form of salts and are considered ignitible (D001) because of the presence of silver nitrate $\left(\mathrm{AgNO}_{3}\right)$. The dangerous waste may be considered toxic, dangerous waste (WTO2) and/or carcinogenic, dangerous waste (WCO2).

All existing facitities must include photographs foerig/ or ground-lovell thot clearly de lineate all oxisting structures; existing storage, tre atment and disposal areas; and sitos of future storage, treatment or disposal areas isoe inst/uctions for more detaill.

VII. FACILITY GEOGRAPHIC LOCATION This information is provided on the attached drawings and photos.

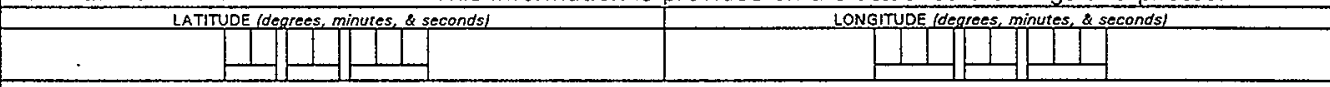

VIII. FACILITY OWNER

A. If the facility owner is also the facility operator as listed in Section Vil on Form 1, "Genoral information", place an $x^{*}$ in the box to the left and skip to section IX bolow.

B. If the facility owner is not the facility operator as listed in Section VII on form 1, complete the following items:

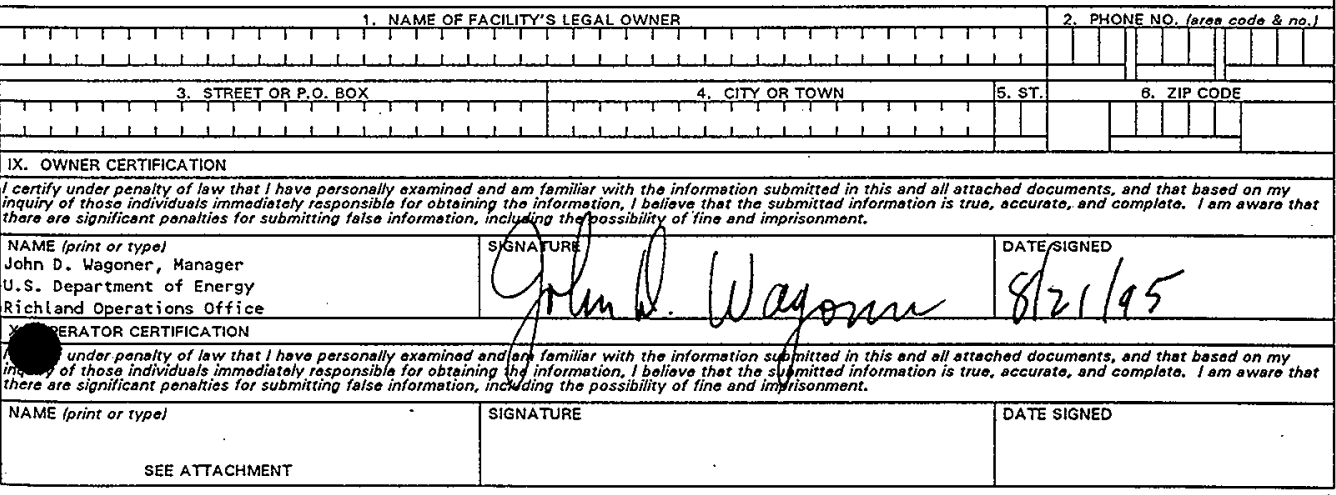


PUREX Storage Tunnels

Rev. 3, 08/21/95, Page 5 of 9

X. OPERATOR CERTIFICATION

I certify under penalty of law that I have personally examined and am familiar with the information submitted in this and all attached documents, and that based on my inquiry of those individuals immediately responsible for obtaining the information, I believe that the submitted information is true, accurate, and complete. I am aware that there are significant penalties for submitting false information, including the possibility of fine and imprisonment.
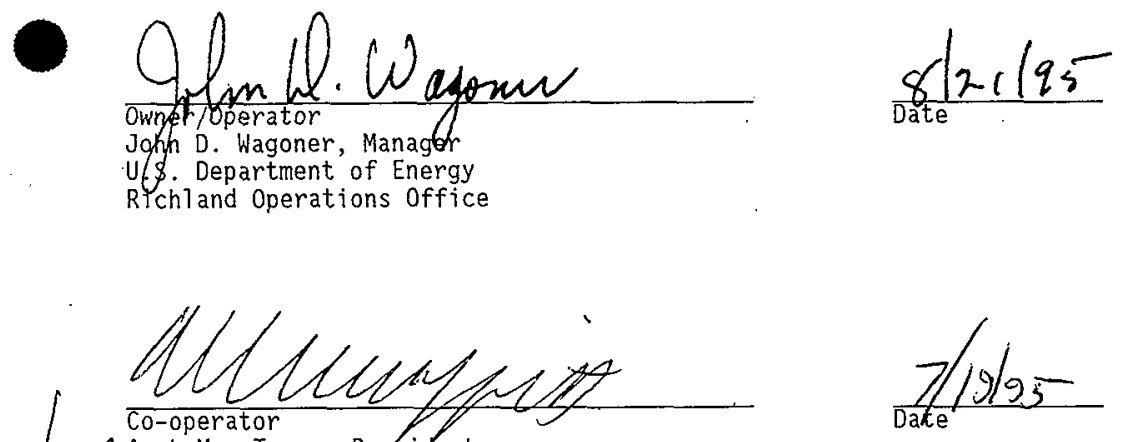

A. LaMar Trego, President Westinghouse Hanford Company 


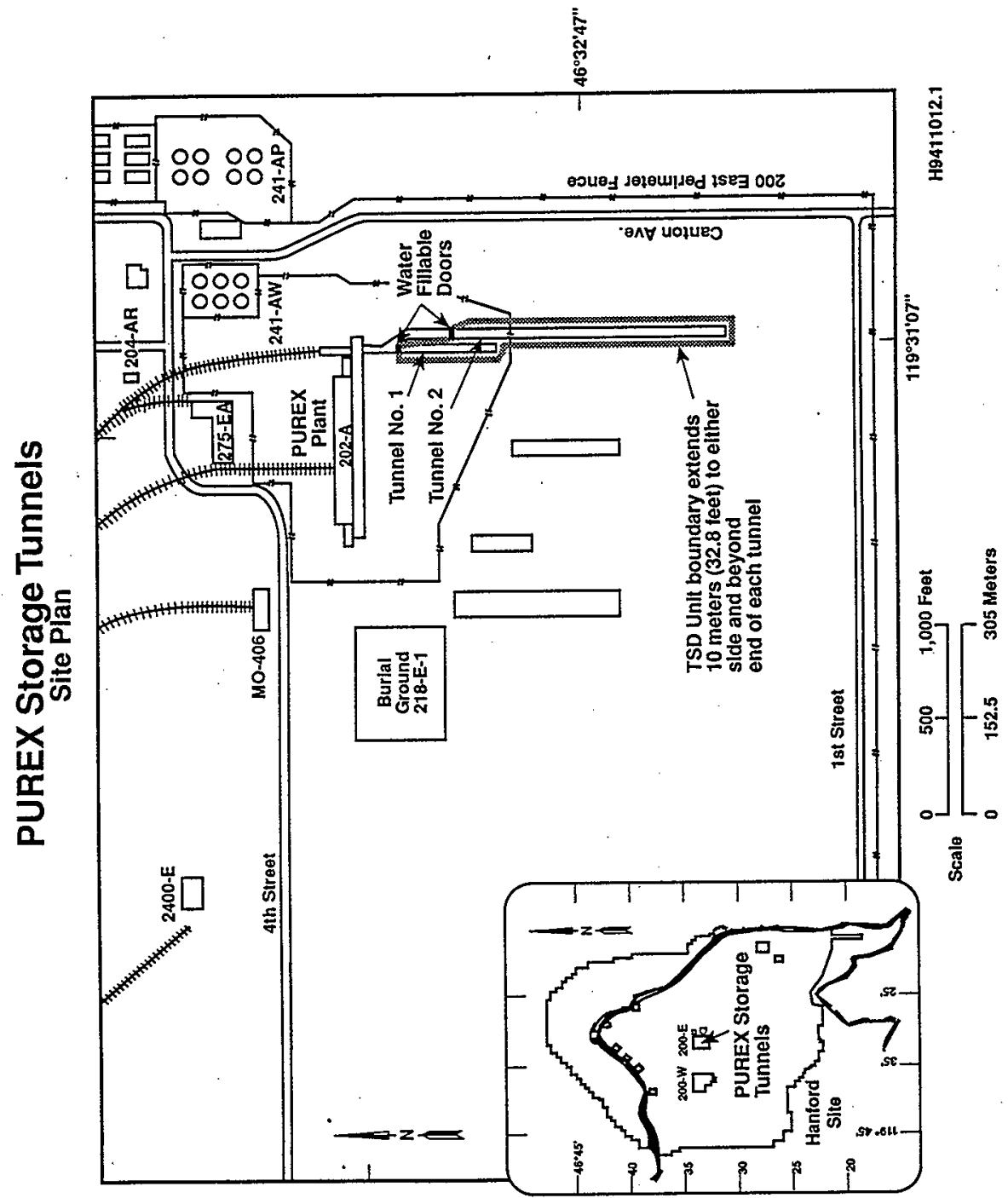




\section{PUREX TUNNEL NO. 1 - DETAILS}

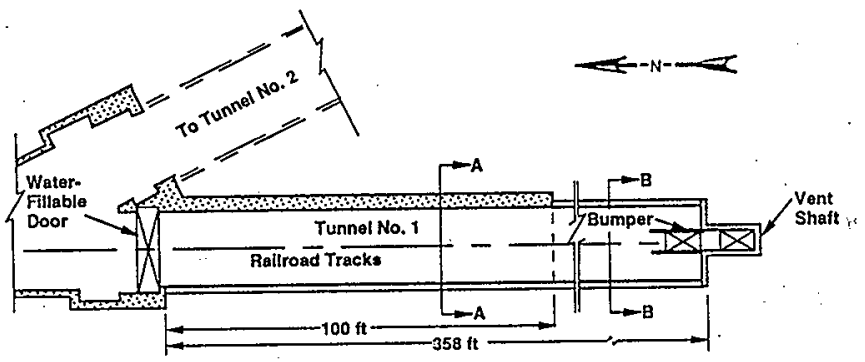

Tunnel No. 1 - Plan View

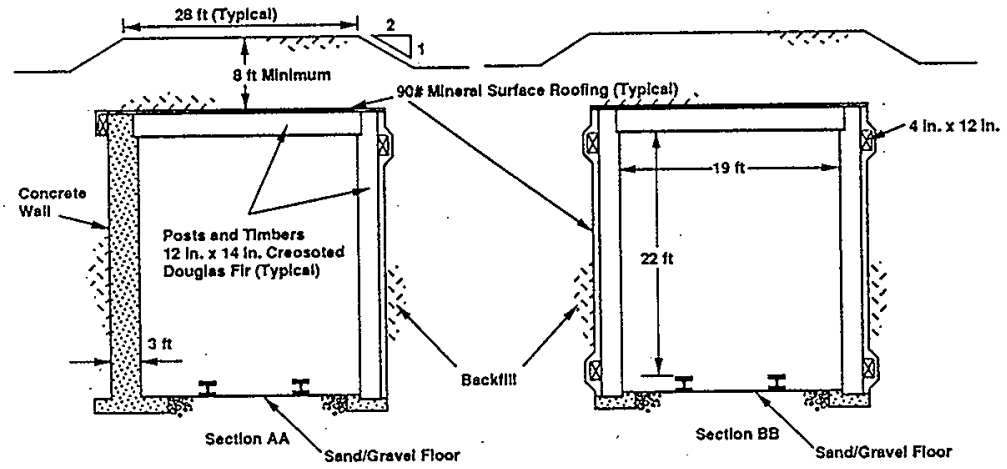

PUREX Tunnel No.1. Section Views

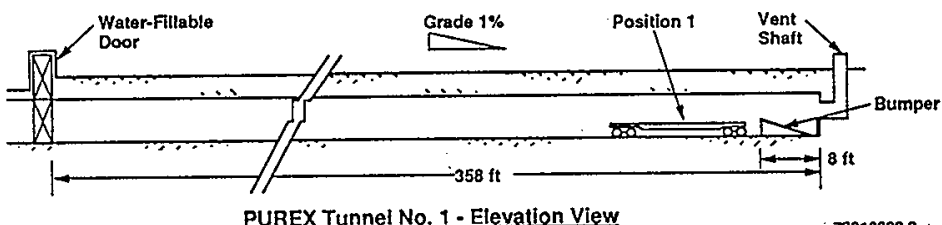




\section{PUREX TUNNEL NO. 2 - DETAILS}

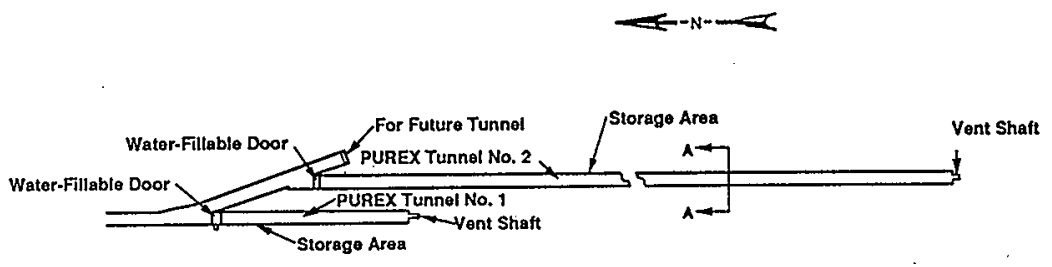

\section{PUREX Tunnels - Plan View}
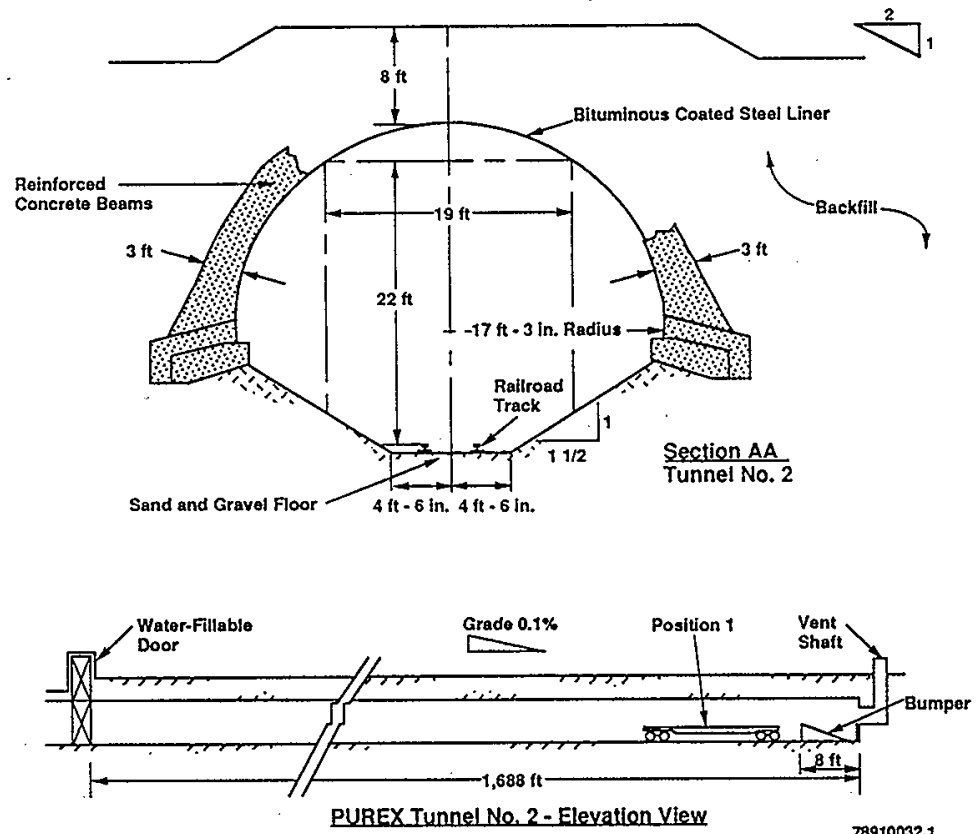

For conversion to meters, multiply feet by 0.3048

For conversion to centimeters, multiply inches by 2.54 


\section{PUREX STORAGE TUNNELS}

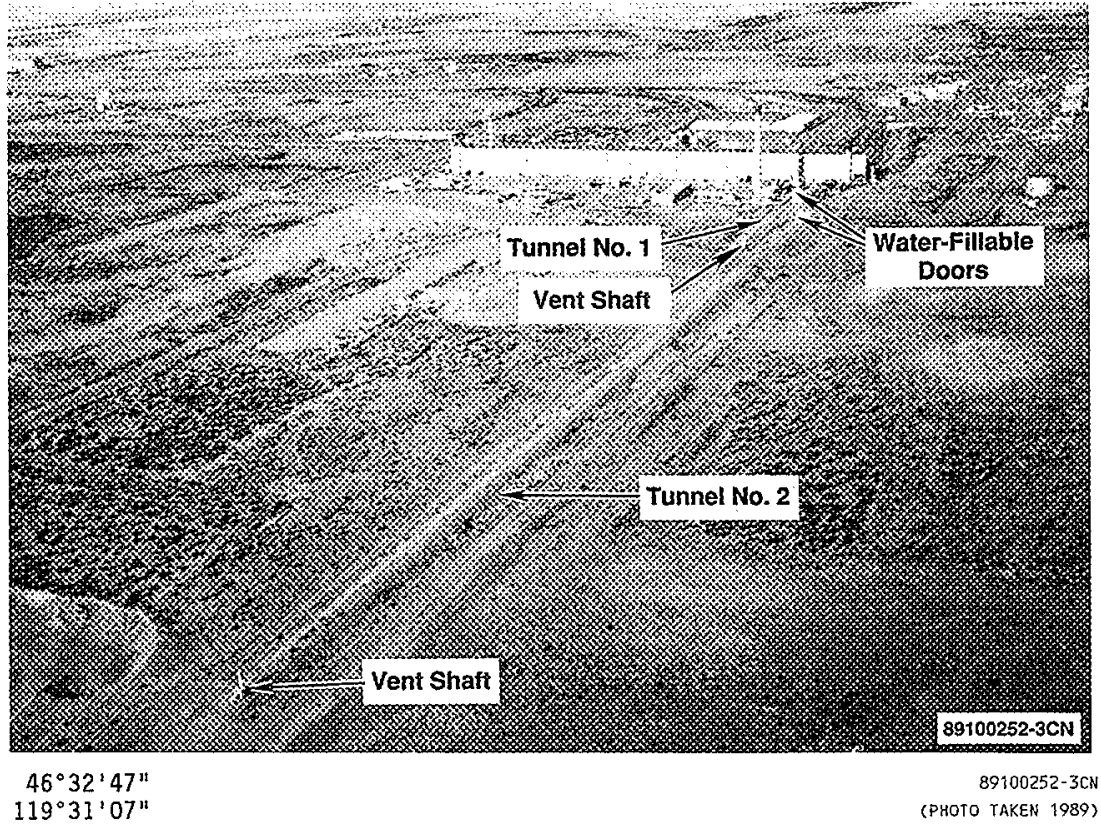




\section{CONTENTS}

2.0 FACILITY DESCRIPTION AND GENERAL PROVISIONS [B AND E] $\ldots . . . . .2-1$

2.1 THE PUREX STORAGE TUNNELS DESCRIPTION [B-1] . . . . . . . . . 2-1

2.1.1 Tunne1 Number 1 (218-E-14) . . . . . . . . . . 2-2

2.1.2 Tunnel Number $2(218-E-15)$........... 2-4

2.1.3 Other Environmental Permits . . . . . . . . 2-5

2.2 TOPOGRAPHIC MAP $[8-2] \ldots \ldots \ldots . \ldots . \ldots 2-5$

2.3 TRAFFIC INFORMATION FOR THE PUREX STORAGE TUNNELS [B-4] . . . . 2-6 2.3.1 The PUREX Storage Tunnels Roadway Access . . . . . . . . 2-6

2.3.2 The PUREX Storage Tunnels Railroad Access . . . . . : . 2-6

2.4 RELEASE FROM SOLID WASTE MANAGEMENT UNITS [E] . . . . . . . 2-6

\section{APPENDIX}

$2 A$ TOPOGRAPHIC MAP ................... APP $2 A-i$

\section{FIGURES}

2-1. The 200 East Area ................... . . F2-1

2-2. The PUREX Facility ..................... . F2-2

2-3. The PUREX PTant (Building 202-A) ................. F2-3

2-4. The PUREX Storage Tunnel Number 1 . . . . . . . . . . . . . F2-4

2-5. The PUREX Storage Tunnel Number 2.............. . F2-5

2-6. Estimated Traffic Volumes . . . . . . . . . . . . . . . F2-6 
DOE/RL-90-24, Rev. 2

11/95

1

2

3

4

5

This page intentionally left blank. 
DOE/RL-90-24, Rev. 2

$11 / 95$

\subsection{FACILITY DESCRIPTION AND GENERAL PROVISIONS [B AND E]}

This chapter briefly describes the PUREX Storage Tunnels location and operational information, including the following:

- General description

- Topography

- Traffic information.

A more detailed discussion of the waste types, known characteristics, and operating methods of the PUREX Storage Tunnels is provided in Chapters 3.0 and 4.0 , respectively. Because dangerous waste is not considered by the DOE-RL to include the source, special nuclear, and by-product material components of mixed waste, radionuclides are not within the scope of this permit application documentation. The information on radionuclides is provided only for general knowledge.

The PUREX Facility, located in the 200 East Area (Figures 2-1 and 2-2), consists of two separate treatment, storage, and/or disposal (TSD) unjts, the PUREX Plant (202-A Building) and the PUREX Storage Tunnels.

In 1991, the PUREX Plant ceased operations and was placed in a standby mode. In December 1992, the U.S. Department of Energy not ified the U.S. Department of Energy, Richland Operations office (DOE-RL) that the PUREX Plant would no longer operate and directed the PUREX Plant to transition into deactivation. The PUREX Storage Tunnels provide direct support to transition activities by accepting PUREX PIant waste material for storage. On a case-bycase basis, the PUREX Storage Tunnels could accept waste generated from other sources on the Hanford Facility.

Access to the PUREX Storage Tunnels is by means of the railroad tunnel. The reinforced concrete walls and raof of the railroad tunnel that extend southward have been deleted from Figure 2-3 to show the cask car and the extended railroad track.

\subsection{THE PUREX STORAGE TUNNELS DESCRIPTION [B-1]}

The PUREX Storage Tunnels branch off from the railroad tunnel and extend southward from the east end of the PUREX Plant (Figure 2-2). The tunnels are used for storage of mixed waste from the PUREX P1ant and from other onsite sources. Each storage tunnel is isolated from the railroad tunnel by a water-fillable shielding door. There are no electrical utilities, water lines, drains, fire detection or suppression systems, radiation monitoring, or communication systems provided inside the PUREX Storage Tunnels.

Material selected for storage is loaded on railcars modified to serve as both transport and storage platforms. Normaliy, a remote-controlled, battery-powered locomotive is used to position the railcar in the storage tunnel. In the past and possibly in the future, other remote movers, e.g., standard locomotive with a string of railcar spacers, power winch, etc., have 
1 or could be used to position a railcar into the tunnel or to withdraw a car

2 from the tunnel. The railcar storage positions are numbered sequentially,

3 commencing with Position 1 that abuts the rajistop bumper at the south end of

4 each tunnel. Position 2 is the location of the railcar that abuts the railcar

5 in Position 1 and so forth. The railcars and material remain in the storage tunnel until retrieval is required. Each railcar is retrievable; however, because the railcars are stored on a single, dead-end railroad track, the railcars can be removed only in reverse order (i.e., Tast in, first out).

Transfers into or out of the PUREX Storage Tunnels are infrequent and are not manpower-intensive operations. A more detailed description of the operation of the PUREX Storage Tunnels is provided in Chapter 4.0 .

\subsubsection{Tunne1 Number 1 (218-E-14)}

Construction of Tunnel Number 1 was completed in 1956 and consists of three areas: the water-fillable door, the storage area, and the vent shaft (Figure 2-4). The water-fillable door is located at the north end of Tunnel Number 1 and separates the storage tunnel from the PUREX railroad tunne1. The door is 7.5 meters high, 6.6 meters wide, and 2.1 meters thick, and is constructed of 1.3 centimeter steel plate. The door is hollow so that the door can be filled with water to act as a radiation shield when the door is in the down (closed) position. If the door is filled with water, the water must be pumped from the door before the door can be raised.

Above the door is a reinforced concrete structure into which the door is raised to open the tunnel. Electric hoists used for opening and closing the door are located on the top of this concrete structure.

Pumps and valves used for filling and draining the door are located in a room northwest of the door closure. Operational controls are located in the PUREX Plant on the north wall at the east end of the pipe and operating ga11ery.

Beneath the water-fillable door is a sump with a 15.2-centimeter drain that connects to a railroad tunnel sump that can be pumped out to the 200 Area Treated Effluent Disposal Facility. This sump will be capped as part of deactivation activities.

The storage area is that portion of the tunnel that extends southward from the water-fillable door. Inside dimensions of Tunnel Number 1 are 109.1 meters long, 6.7 meters high, and 5.9 meters wide. Ceiling and waTls are 35.6 centimeters thick and constructed of 30.5 - by 35.6 -centimeter creosote pressure-treated Douglas fir timbers arranged side by side. The first 30.5 meters of the east wall are constructed of 0.9 -meter-thick reinforced concrete (Section AA of Figure 2-4). A 40.8-kilogrammineral-surface roofing material was used to cover the exterior surface of the timbers before placement of 2.4 meters of earth fill. The earth cover serves as protection from the elements and as radiation shielding. The timbers that form the walls rest on reinforced concrete footings 0.9 meter wide by

520.3 meter thick. The floor consists of a railroad track laid on a grave 1 bed. 
1 The space between the ties is filled to top-of-tie with gravel ballast. The

2 tracks are on a 1.0 percent downward slope to the south to ensure that the

3 railcars remain in their storage position. A railcar bumper is located

42.4 meters from the south end of the tracks to act as a stop. The capacity of

5 the storage area is eight, 12.8-meter-iong railcars.

From 1962 through 1980, nine pipe risers were installed through the roof of Tunnel Number 1 . Seven of the nine risers were used for wood sampling of the tunnel ceiling timbers. The other two risers were used to obtain air samples and temperature data of the internal environment of the tunnel. Currently, all risers are capped:

The results of the wood strength survey (conducted in 1980) concluded that the wood beams in Tunnel Number 1 were within standards for present day wood. Design calculations performed at the time al'so found the tunnel to be "within safe limits" (Silvan 1980). Air sampling conducted in Tunne? Number I did not identify the presence of any combustible gases and found oxygen 1evels to be at about 21 percent with carbon dioxide at about 0.3 percent. The reported temperature in Tunnel Number 1 remains consistent at $15.6{ }^{\circ} \mathrm{C}$ (Rambosek and Foster 1972).

An independent evaluation of the 1980 data collected by Silvan was conducted in 1991 to further evaluate the structural integrity of PUREX Storage Tunnel Number 1 (Hand and Stevens 1991). This study concluded that any degradation of the treated timbers because of decay or insect attack should be minimal and found that the tunnel timbers structurally should be sound. This study also confirmed the reasonableness of the values used and agreed with the findings of the Silvan study. In addition, the study conciuded that the methods used by Silvan to calculate the loss of timber strength were sufficiently conservative to accurately determine the soundness of the timbers. The exposure of the timbers to the high gamma radiation field emitted by the material stored within the tunnel was factored into the evaluation.

A vent shaft is located at the south end of Tunnel Number 1. The shaft is approximately 1.5 meters by 1.5 meters in cross-section and is constructed of reinforced concrete. The vent stack extends approximately 0.3 meter above grade and was capped with a single-stage, high-efficiency particulate air (HEPA) fi7ter, a 283-cubic-meter per minute exhaust fan, and a 6.1-meter ta11 exhaust stack. After filling Tunnel Number 1 to capacity, the tunnel was sealed. Sealing activities included de-energizing the ventilation system and blanking the ventilation system upstream of the air filters to prevent interaction of the tunnel air with external air. A further discussion of the tunnel ventilation system iș provided in Chapter 4.0.

In June 1960, the first two railcars were loaded with a single, approximately 12.5-meter-long, failed separation column and placed in Tunnel Number 1. Between June 1960 and January 1965, six more railcars were placed in Tunnel Number 1 , filling the tunnel. After the last car was placed in the northern-most storage position (Position 8), the water-fillable door was closed, filled with water, and deactivated electrically. The Tunnel Number 1 door will be drained as part of PUREX Facility transition activities. 


\subsubsection{Tunnel Number 2 (218-E-15)}

Construction of Tunnel Number 2 was started and completed in 1964 . Like Tunnel Number 1, Tunnel Number 2 consists of three functional areas: the water-fillable door, the storage area, and the vent shaft. Construction of Tunnel Number 2 differs from that of Tunnel Number 1 as follows.

- A combination of steel and reinforced concrete was used in the construction of the storage area for Tunnel Number 2 (Figure 2-5) rather than wood timbers, as used in Tunnel Number 1.

- Tunnel Number 2 is longer, having a storage capacity of five times that of Tunnel Number 1 .

- The floor of Tunnel Number 2, outboard of the railroad ties, slopes upward to a height of approximately 1.8 meters above the railroad bed, whereas the floor in Tunnel Number 1 remains flat all the way out to the side walls.

- The railroad tunnel approach to Tunnel Number 2 angles eastward then angles southward to parallel Tunnel Number 1 (Figure 2-4). The approach to Tunnel Number 1 is a straight extension southward from the PUREX Plant. Center-line to center-line distance between the two tunnels is approximately 18.3 meters.

The physical structure of the water-fillable door at the north end of Tunnel Number 2 essentially is identical to the water-fillable door for Tunnel Number 1. The water-fillable door for Tunnel Number 2 is approximately 57.9 meters south and 18.3 meters east of the water-fillable door for Tunne? Number 1 (Figure 2-2).

Controls for operation of the water-fillable door are located above the tunnel on the east exterior wall of the door enclosure (Chapter 4.0, Figure 4-1). Chapter 4.0 provides additional operational information on the Tunnel Number 2 water-fillable door. As of February 9, 1995, the door is empty and there are no plans to fill it. Procedures for filling and draining the door are presented in Chapter 4.0.

The storage area of Tunnel Number 2 is that portion of the tunnel extending southward from the water-fillable door. Construction of this portion of Tunnel Number 2 consists of a 10.4-meter diameter, stee] ( 0.5 centimeter plate), semicircular-shaped roof, supported by internal I-beam wales attached to external, reinforced concrete arches. The concrete arches are 0.4-meter thick and vary in width from 0.4 to 1.8 meters. The arches are spaced on 4.8-meter centers. This semicircular structure is supported on reinforced concrete grade beams approximately 1.8 meters wide by 1.2 meters thick (one on each side) that run the futl length of Tunnel Number 2 . The interior and exterior surfaces of the stee? roof are coated with a bituminous coating compound to inhibit corrosion. The entire storage area is covered with 2.4 meters of earth fill to serve as radiation shielding. 
The nominal inside dimensions of Tunnel Number 2 are 514.5 meters long, 7.9 meters high, and 10.4 meters wide. However, because of the arch-shaped cross-section of Tunnel Number 2 and entry clearance at the water-fillable door, the usable storage area (width and height above top-of-rail) is 6.7 meters high and 5.8 meters wide, the same dimensions as for Tunnel Number 1 . The floor consists of a railroad track laid on a gravel bed. The space between ties is filled to top-of-tie with gravel ballast. Commencing at the ends of the 2.4-meter-long ties, the earth floor is sloped upward on a 1 (vertical) to $11 / 2$ (horizontal) grade. The tracks are on a $1 / 10$ of 1 percent downgrade slope to the south to ensure the railcars remain in their storage position. A railcar bumper is located 2.4 meters from the south end of the tracks to act as a stop. The capacity of the storage area is 40 , 12.8-meter-long railcars.

There are 17 tunnel ports located along the ridge of. the tunnel roof (for details, refer to Drawing $\mathrm{H}-2-58195$ in Appendix 4A). The ports are on 29.3-meter centers. A 7.6-centimeter diameter bar plug is located in the center of each tunnel port and is secured in place with a length of chain and a padlock. The PUREX Plant operations administers access control of these tunnel ports.

The vent shaft, located at the south end of Tunnel Number 2, is approximately 1.5 meters by 1.5 meters in cross-section and is constructed of reinforced concrete. The vent shaft extends approximately 0.3 meter above grade and is capped with an exhaust system consisting of a single-stage, HEPA filter, a 153-cubic meter per minute exhaust fan, and a 6.1 -meter-tal1 exhaust stack. The ventilation system current]y is active; however, the exhaust fan has been dampered to provide only about 100 cubic meters per minute of exhaust flow. A further discussion of the tunnel ventilation system is provided in Chapter 4.0 .

The first railcar was placed in storage in December 1967. As of October 1995, 21 railcars have been placed in Tunnel Number 2 .

\subsubsection{Other Environmental Permits}

Federal and state laws and local requirements applicable to the PUREX Storage Tunnels are listed in Chapter 13.0 and discussed in Chapter 13.0 of the General Information Portion (DOE/RL-91-28).

\subsection{TOPOGRAPHIC MAP [B-2]}

A topographic map (Drawing $\mathrm{H}-2-79998$ ), showing a distance of at least 305 meters around the PUREX Storage Tunnels, is located in Appendix $2 A$. This map is at a scale of 1 unit equals 2,000 units. The contour interval clearly shows the pattern of surface water flow in the vicinity of each storage tunnel. The map contains the following information:

- Map scale

- Date 
- Prevailing wind speed and direction

- A north arrow

- Surrounding land use

- Büildings

- Access road location

- Access control

- Monitoring and sampling well locations

- TSD unit locations.

\subsection{TRAFFIC INFORMATION FOR THE PUREX STORAGE TUNNELS [B-4]}

General traffic information for the Hanford Facility is presented in the General Information Portion (DOE/RL-91-28).

\subsubsection{The PUREX Storage Tunnels Roadway Access}

The paved roads providing access to the 200 East Area and the PUREX Facility also provide adequate all-weather access to the external portions of the PUREX Storage Tunnels (Figure 2-1). A paved parking area is provided northwest of the main gate.

\subsubsection{The PUREX Storage Tunnels RaiTroad Access}

Railroad access to the PUREX Storage Tunnels is by an extension of the railroad spur that services the PUREX Plant (Figure 2-2).

\subsection{RELEASE FROM SOLID WASTE MANAGEMENT UNITS [E]}

Information concerning releases from solid waste management units is discussed in the General Information Portion (DOE/RL-91-28). 


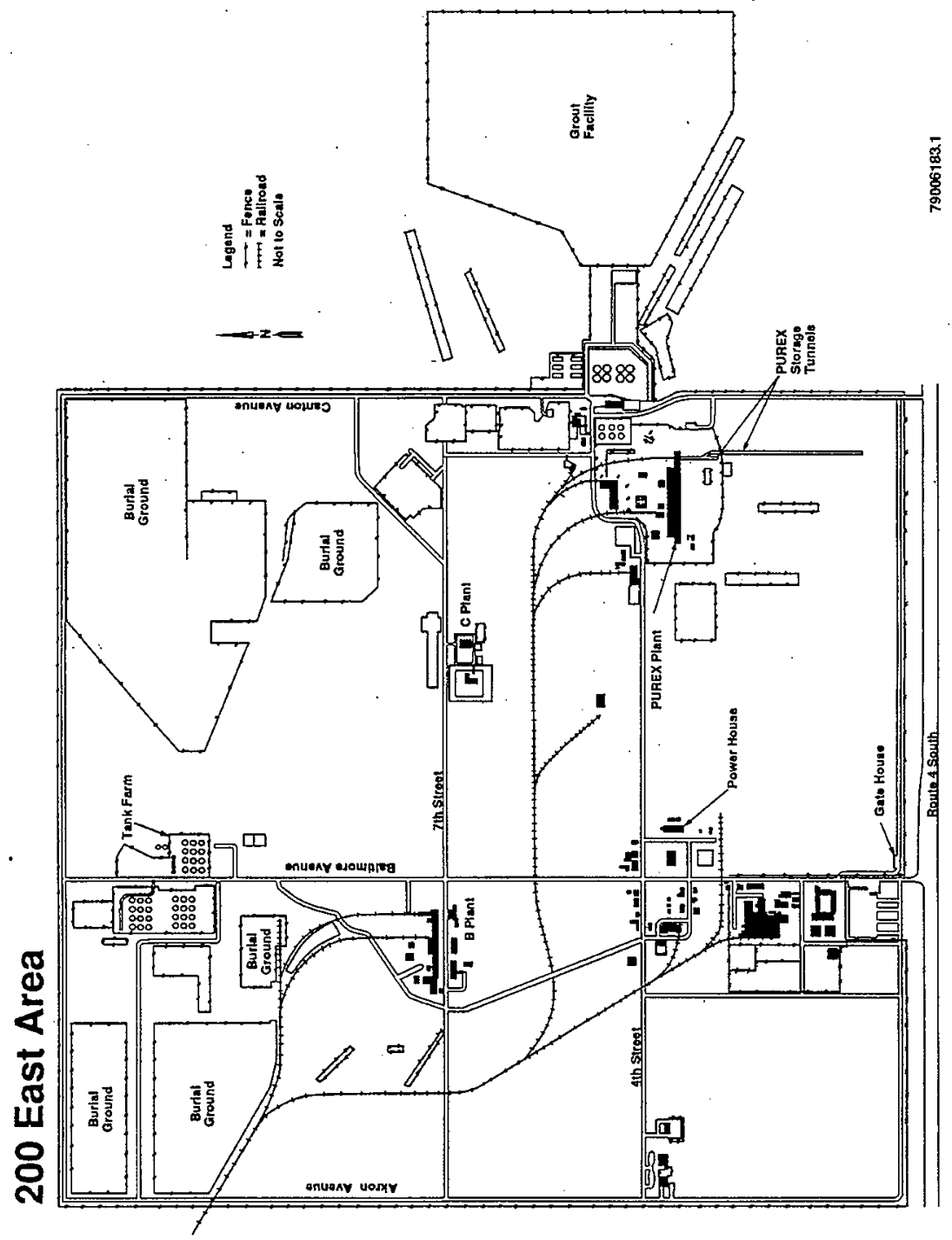

Figure 2-1. The 200 East Area. 
DOE/RL-90-24, Rev. 2

$11 / 95$

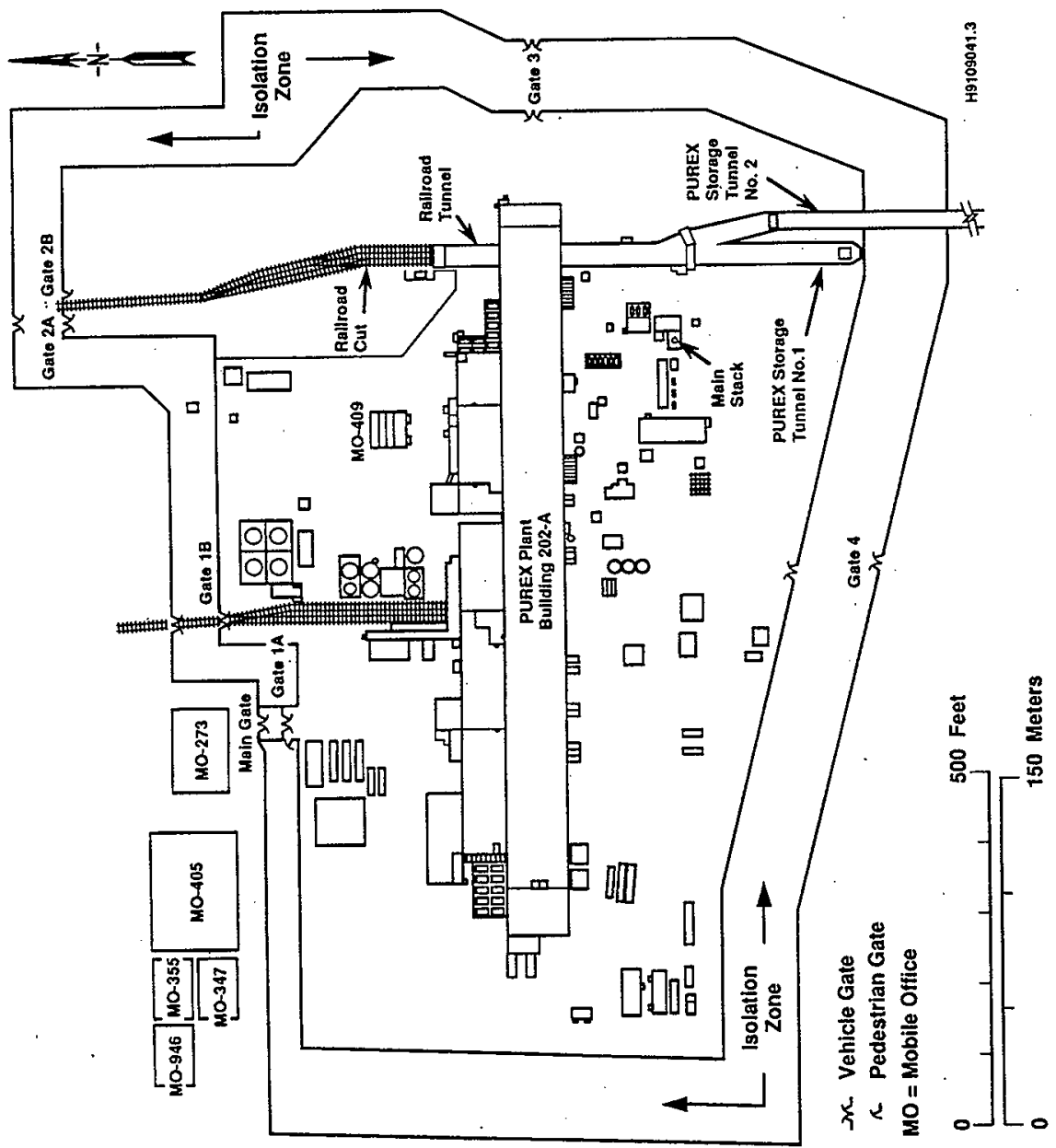

Figure 2-2. The PUREX Facility. 


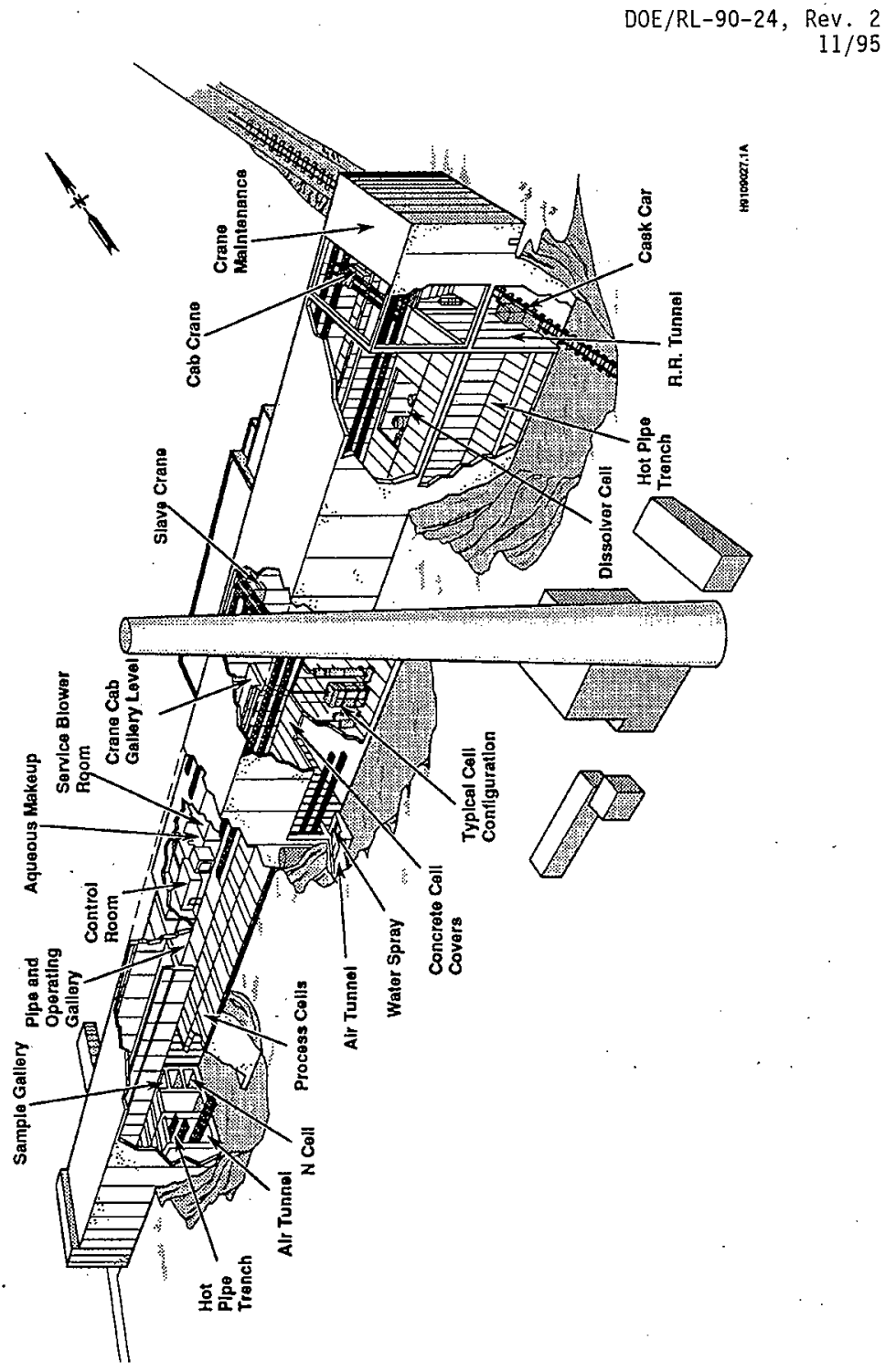

Figure 2-3. The PUREX Plant (Building 202-A). 


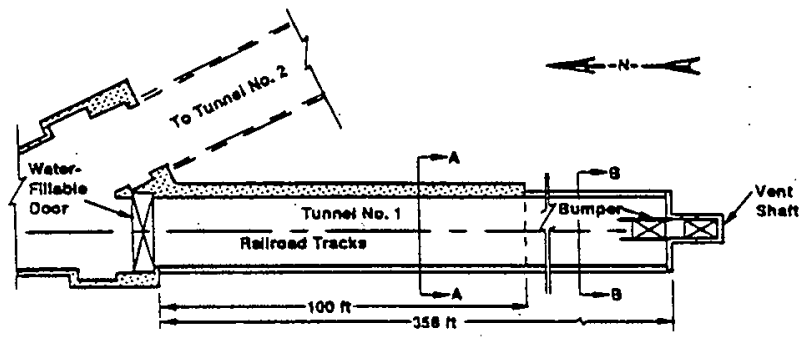

Iunned Ne. 1-Plan Vlew

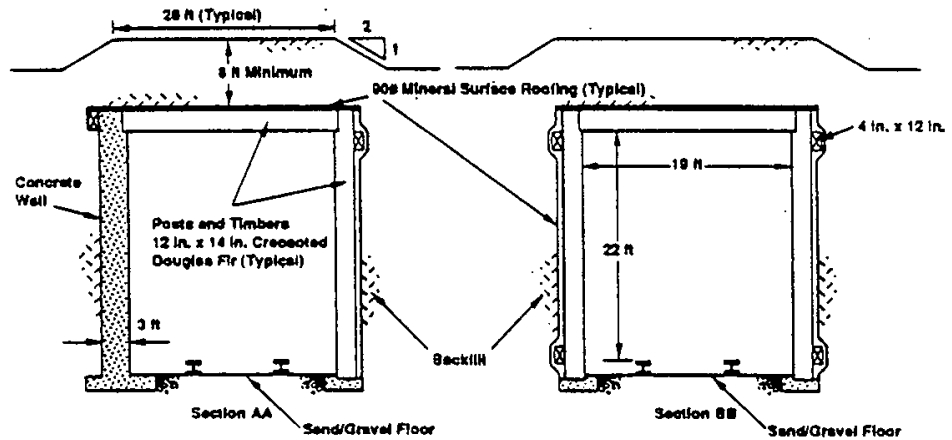

PUREX Tunnel No. 1 + Sectlon Vlaws

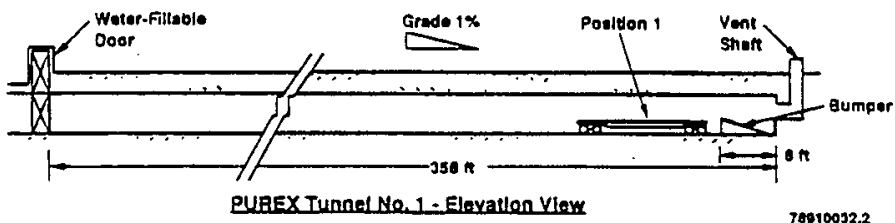

Figure 2-4. The PUREX Storage Tunnel Number 1. 

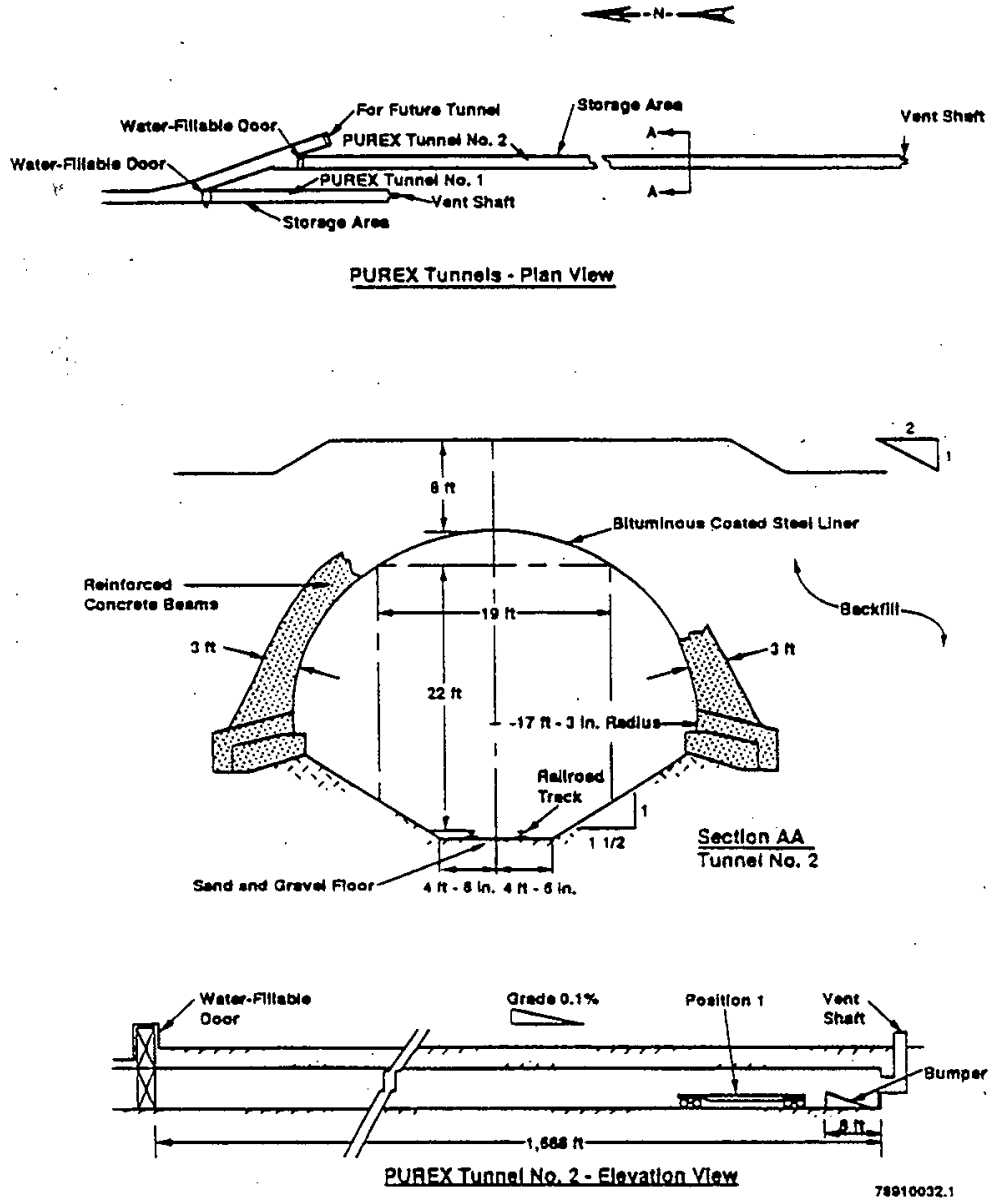

Figure 2-5. The PUREX Storage Tunnel Number 2. 


\section{CONTENTS}

3.0 WaSte analySIS $[C] \ldots \ldots$ 3-1

3.1 CHEMICAL, BIOLOGICAL, AND PHYSICAL ANALYSES [C-1]..... 3-1

3.2 WASTE ANALYSIS PLAN $[\mathrm{C}-2] \ldots \ldots$. . . . . . . . . . .

3.3 TRACKING SYSTEM $[C-4] \ldots \ldots$. . . . . . . . . .

APPENDIX

16

17

3 A WASTE ANALYSIS PLAN FOR PUREX STORAGE TUNNELS ....... APP 3A-i 
DOE/RL-90-24, Rev. 2

$11 / 95$

This page intentionally left blank. 


\subsection{WASTE ANALYSIS [C]}

This chapter provides information on the chemical, biological, and physical characteristics of the dangerous waste stored in the PUREX Storage Tunnels. A waste analysis plan (Appendix 3A) describes the methodology used in the characterization of the stored waste. Knowledge of the characteristics of the dangerous waste to be stored is used to ensure that the waste is managed properly.

Waste stored in the tunnels is mixed waste as a result of radioactive contamination. Because the dangerous waste is an integral part of radioactively contaminated material, this waste is managed as a mixed waste. The PUREX Storage Tunnels provide the necessary shielding for the protection of employees and the environment. Presently, one-third of the railcars in the PUREX Storage Tunnels store material that contains dangerous waste components (mixed waste).

\subsection{CHEMICAL, BIOLOGICAL, AND PHYSICAL ANALYSES [C-1]}

Presently, material stored in the PUREX Storage Tunnels contains the following dangerous waste:

- Lead

- Mercury

- Silver and silver salts

- Chromium

- Cadmium.

Dangerous waste is either attached to, contained within, or actually is material removed from the PUREX Plant and other onsite sources. Changes in the amount of dangerous waste stored will be updated annually in the annual dangerous waste report submitted to Ecology. Future storage of barium and selenium may occur in Tunnel Number 2. Further discussion of waste types is included in the waste analysis plan (Appendix $3 A$ ).

The PUREX Storage Tunnels are being permitted as a miscellaneous unit under WAC 173-303-680 because the tunnels are not a typical containerized storage unit. That is, the bulk of the material stored in the tunnels is not placed in a container; rather, this material is placed on a portable device (railcar) used as a storage platform. In general, the mixed waste stored in the PUREX Storage Tunnels is encased or contained within carbon or stainless steel plate, pipe or vessels that meets the WAC 173-303-040 definition of container. Therefore, the mixed waste normally is not exposed to the tunnel environment.

The only free-liquid dangerous waste stored in the tunnels is elemental mercury. The mercury is contained within thick-walled (0.8-centimeter) thermowells. The amount of mercury per thermowell is less than 1.7 1iter. 
Other liquid containers, such as Targe discarded process tanks, are stored in the PUREX Storage Tunnels. These containers are 'empty'

[per WAC 173-303-160(2)(a)]. In the future containers will be flushed and the final rinsate sampled and analyzed to verify that the residual heel is not a. dangerous waste.

The only stored mixed waste that is designated as either reactive or ignitable (0001) is silver nitrate in the silver reactors

[WAC 173-303-090(5)]. There is no mixed waste designated as reactive (D003). The potential for ignition from this source is considered to be negligible because this material is dispersed on ceramic packing and is physically isolated from contact with any combustible material or ignition source.

\subsection{WASTE ANALYSIS PLAN [C-2]}

The Waste Analysis Plan for the PUREX Storage Tunnels is provided in Appendix $3 A$.

\subsection{TRACKING SYSTEM [C-4]}

Specific waste tracking forms for the movement of waste destined for the PUREX Storage Tunnels are used. These waste tracking forms effectively track waste inventories from generation through storage.

The waste tracking forms and other supporting documentation will be maintained at the Hanford Facility for a minimum of 5 years following closure of the PUREX Storage Tunnels. 


\section{CONTENTS}

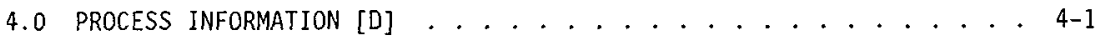

4.1 OPERATION OF THE PUREX STORAGE TUNNELS . . . . . . . . . 4-1

4.1.1 Preparation for Tunnel Activities ......... 4-1

4.1.1.1 Storage/Removal Equipment Preparation ..... 4-1

4.1.1.2 Water-Fillable Door Preparation . . . ... . . 4-2

4.1.1.3 Other Preparation Tasks .......... 4-2

4.1.2 Tunnel Storage Activities . . . . . . . . . . 4-2

4.1.2.1 Physical Characterization of Material to be Stored ............ 4-2

4.1.2.2 Material Flushing ............ . 4-3

4.1.2.3 Railcar Preparation ......... 4-3

4.1.2.4 Placement of Material into Storage

Position .......... 4-3

4.1.3 Removal of Stored Materiaj . . . . . . . . . . 4-4

4.1.4 Filling the Water-Fillable Door (Tunnel Number 2) . . . 4-4

4.1 .5 Poststorage Activities........... 4-5

4.1.6 Operation of the Tunnel Ventilation System . . . . 4-5

4.1.6.1 Tunne? Number 1 Ventilation........ 4-5

4.1.6.2 Tunnel Number 2 Ventilation ........ 4-5

4.2 CONTAINERS $[\mathrm{D}-1] \ldots \ldots \ldots$. . . . . . . . . . . . . .

4.2.1 Containers with Free Liquids . . . . . . . . . 4-6

4.2.2 Containers Without Free Liquids That Do Not Exhibit

4.2.3 Protection of Extremely Hazardous Waste in Containers , 4-7

4.2.4 Prevention of Reaction of Ignitable, Reactive, and Incompatible Waste in Containers . . . . . . . . 4-8

\section{APPENDIX}

4 A ENGINEERING DRAWINGS ....................... 4 AP-

45 4-1. Water-Fillable Door Exterior (Tunnel Number 2) . . . . . . . F4-1

FIGURE 
DOE/RL-90-24, Rev. 2

This page intentionally left blank. 
DOE/RL-90-24, Rev. 2

$11 / 95$

\subsection{PROCESS INFORMATION [D]}

This chapter discusses the processes involved in the operation of the PUREX Storage Tunnels. The PUREX Storage Tunnels are used for the storage of mixed waste from the PUREX Plant and other onsite sources.

The PUREX Storage Tunnels were designed and constructed to provide a means of protecting personnel and the environment from radiation associated with stored material. This design also serves to protect personnel and the environment from the dangerous waste component of the mixed waste stored inside the tunnels. A physical description of the PUREX Storage Tunnels is provided in Chapter 2.0 .

The PUREX Storage Tunnels are being permitted as a miscellaneous unit under WAC 173-303-680. The WAC regulations require that miscellaneous unit permit terms and provisions address appropriate requirements provided for other TSD units. Because the operation and construction of the PUREX Storage Tunneis most closely resemble that of a container storage unit, the appropriate requirements prescribed for a container storage unit are addressed in this chapter.

\subsection{OPERATION OF THE PUREX STORAGE TUNNELS}

This section describes the selection, characterization, preparation, placement, and removal activities associated with storage of mixed waste in the PUREX Storage Tunnels. Except as noted, these activities also apply to the storage of radioactive waste placed in the PUREX Storage Tunnels.

\subsubsection{Preparation for Tunnel Activities}

Management, with the concurrence of an appropriate cognizant engineer, determines when material is to be removed and transported to the PUREX Storage Tunnels. A job specific work plan describing the overall transfer activities is prepared.

4.1.1.1 Storage/Removal Equipment Preparation. A remotely controlled, battery-powered locomotive normally is used to move rajlcars into and out of the PUREX Storage Tuninels. Other mechanical means such as a standard locomotive or a winch also can be used independently or in combination with the remote locomotive should the need arise. Methods for use of the remote locomotive are described in this chapter as this represents the normal placement and removal of railcars at the PUREX Storage Tunnels. Should storage activities require the use of a mechanical means other than the remote locomotive to place or withdraw a railcar, methods for that application will be developed.

Preparatory activities associated with the remote-controlled locomotive include the following: 


\subsubsection{Tunnel Storage Activities} Tunnels.

4.1.1.2 Water-Fillable Door Preparation. Each PUREX Storage Tunnel has a water-fillable door that isolates the storage area from the PUREX railroad tunne1. (Chapter 2.0 provides a description of the door.)

Currentiy, the water-fillable door to Tunnel Number 2 is empty and is not expected to be filled. Operational checks are performed on the door hoists. Before performing operational checks on the water-fillable door, the operator confirms with a dispatcher that the railroad tunnel area is clear of personne?.

4.1.1.3 0ther Preparation Tasks. Before materia1 storage, the following preparatory tasks are completed.

- The storage tunnel exhaust fan is verified to be operating.

- Labels will be attached to the railcar in accordance with WAC 173-303-395(6) and 173-303-630(3) if the material contains dangerous waste components.

4.1.2.1 Physical Characterization of Material to be Stored. Physical characterization includes an evaluation of the following physical properties:

- Length, width, and height

- Gross weight and volume

- Preferred orientation for transport and storage

- Presence of mixed waste.

Information sources used in physical characterization include equipment fabrication and installation drawings, operational records, and process knowledge. Physical characterization provides information necessary to 
1 appropriately describe the mixed waste materials. Such information also is

used to design and fabricate, if required, supports on the railcar.

Specific material known to contain constituents that would cause the equipment to be designated as mixed waste is discussed in the waste analysis plan (Appendix 3A). The material includes but is not limited to dissolvers that contain elemental mercury; silver reactors that contain silver salts; jumpers and other equipment that have elemental lead counterweights; a concentrator that contains chromium; neutron absorbing equipment containing cadmium. Characteristics of these materials when stored as mixed waste are described in Chapter 3.0. Waste transferred to the PUREX Storage Tunnels from other than PUREX Plant also would be physically characterized.

\subsubsection{Material Flushing. Before removal from service, the material from} the PUREX Plant will be flushed to minimize-loss of products, to reduce radioactive contamination, and to reduce to nonregulatory levels the concentration of any dangerous chemicals present in a residual heel. In the future the analysis of the rinsate will be used to determine when these goals have been achieved. The analysis of the final flush will be retained as part of the PUREX Storage Tunnel records. Material removed from other onsite units will be prepared for transfer to the tunnels in accordance with this dangerous waste permit application.

\subsubsection{Railcar Preparation. Railcars are modified to serve as dedicated} storage platforms and transporters for material placed in the PUREX Storage Tunnels. The wooden decking on the railcars is removed to minimize the amount of combustible material placed in the PUREX Storage Tunnels. The south coupler is disabled or removed to prevent the railcar from coupling to the railcar stored ahead. Brakes are disabled to ensure free wheeling of the railcar. Steel decking, catch pans filled with absorbent, and equipment cradles are provided as needed to modify the railcar for its specific task.

\subsubsection{P1acement of Material into Storage Position. With all preparations} complete and with the approval of cognizant management, transferring material to the PUREX Storage Tunnels proceeds as follows.

- The water-fillable door to the storage tunnel is opened.

- The railcar is loaded as specified in the storage tunnel checklist.

- An inventory of items loaded on the railcar and a record of their location on the railcar are recorded in the storage tunnel checklist.

- A health physics technician obtains a radiation level survey of the loaded railcar at a distance commensurate with ALARA practices.

- The railcar is pushed into the storage tunnel to its storage position.

- Once the railcar is in position, the water-fillable door is closed. 


\subsubsection{Removal of Stored Material}

Removal of material stored within the PUREX Storage Tunnels is not conducted routinely. It is planned that the material will remain in storage until a means to accommodate processing and repackaging of the material for disposal or further storage or until another final disposition option becomes available. Removal of material from storage within the PUREX Storage Tunnels would proceed after the preparation activities identified in Section 4.1.1.

With all preparations complete and approval of management, removal of material from the storage area of the PUREX Storage Tunnels would proceed as follows.

- The equipment that will be used to remove material is positioned in the PUREX raitroad tunnel.

- Verification is made that the PUREX railroad tunnel is configured properiy to proceed with entrance into the PUREX Storage Tunnels (i.e., tunnel ventilation system is operating, the overhead door is closed and the health physics technician has performed a radiation survey of the area.

- The water-fillabie door is opened.

- The equipment that will be used to remove material is moved into the storage tunnel and connected to the railcar.

- Verification is made that the railcar is connected to the removal equipment and the railcar is extracted from the storage tunnel and positioned within the PUREX railroad tunnel.

- The water-fillable door is closed.

The loaded railcar retrieved from the tunnel would be remotely viewed and radiation measurements may be obtained to determine the possibility of mixed waste containment failure during storage in the PUREX Storage Tunnels. If evidence of containment failure is detected, the specific details (i.e., material, location on railcar, storage position) would be documented and attached to the waste tracking form. This information would be maintained in the files and would be used to establish sampling locations within the tunnels at closure. After remote viewing and radiation surveys, the railcar and associated material may be prepared as required for transfer to an appropriate onsite TSD unit for treatment or further storage.

\subsubsection{Filling the Water-Fillable Door (Tunnel Number 2)}

If radiation shielding beyond that provided by the empty water-fillable door becomes necessary, the door can be filled with water. This is accomplished by connecting a fire hose from the water hydrant to the wall stub on the exterior of the door housing (Figure 4-1). Once the fire hose is in place, the hydrant valve is opened and the door is filled with water. The 
1 hydrant is closed by personnel when a high-level indicator light illuminates.

2 Although attendance by an operator is required at all times during filling 3 operations, should the door overfill, excess water is channeled through a 4 vent/spiti pipe to the door sump. A 15.2-centimeter drain is provided in each 5 door sump. Water accumulated in the door sump flows to the 200 Area Treated 6 Effluent Disposal Facility. The door sump will be sealed during PUREX

7 Facility deactivation.

\subsubsection{Poststorage Activities} task.

The following poststorage activities would conclude the tunnel storage

- Decontamination activities, if required, are performed.

- Management is notified of any unusual conditions observed during. the storage/retrieval activities.

\subsubsection{Operation of the Tunnel Ventilation System}

The ventilation systems for Tunnel Number 1 and Tunnel Number 2 were designed to ventilate air from within the tunnels so the airborne radioactive contamination is vented through a HEPA filtered exhaust system.

4.1.6.1 Tunnel Number 1 Ventilation. Active ventilation of Tunnel Number 1 presently is not provided. After placement of the last railcar into Tunnel Number 1, the tunnel was sealed (Chapter 2.0). As part of the sealing activities, the ventilation fan was deactivated electrically and the exhaust stack and filter were isolated from the system by installing a blank in the tunnel exhaust duct upstream of the filters. In the event railcar removal activities are initiated, it is planned that the ventilation system would be reactivated. Operation of the ventilation system would be similar to that for Tunnel Number 2 .

4.1.6.2 Tunnel Number 2 Ventilation. The Tunnel Number 2 ventilation system presently is operated continuously. As part of PUREX Facility deactivation, the water-fillable door and outer PUREX railroad tunnel door will be temporarily or permanently sealed depending on the future need for storing waste in the tunnel. The ventilation system may be operated continuously, or de-energized and reactivated during waste placement activities. When the determination has been made that Tunnel Number 2 wi11 no longer receive waste, the ventilation system will be blanked and deactivated electrically similar to the Tunnel Number 1 ventilation system. While the Tunnel Number 2 ventilation system is operating and.the water-fillable door is closed, the exhaust system, which discharges approximately 100 cubic meters per minute, maintains a slightly negative pressure in the tunnel. The exhaust air is replaced by infiltration around the water-fillable door and through the porosity of the tunnel structure (e.g., the rail-bed ballast). When the water-fillable door is open (during transfer activities), inward airflow is maintained through the open doorway. This inward airflow channels airborne radioactive contamination 
1 away from both the railroad tunnel and personnel following railcars (if allowed) into the storage turinel. A HEPA filter provides filtration of all exhaust air before release to the atmosphere. The HEPA filter is tested in place at least annually to ensure radioactive particulate removal efficiency. Exhausted air is sampled periodically and analyzed for airborne radionuclides.

\subsection{CONTAINERS [D-1]}

This section describes the various types of containment used to isolate mixed waste stored in the PUREX Storage Tunnels. The PUREX Storage Tunnels are considered to be a miscellaneous unit most closely. resembling that of a container storage unit. The mixed waste stored in the PUREX Storage Tunnels is contained and is not considered a risk to human health or to the environment.

\subsubsection{Containers with Free Liquids}

The only mixed waste stored as a free liquid is elemental mercury. A small quantity, less than 1.7 liters, of mercury is contained in each of the two thermowells attached to and contained within each dissolver (Chapter 3.0). Primary containment of the mercury is provided by the all-welded construction of the thermowell itself, which is fabricated from 7.6-centimeter, Schedule 80, 304L stainless steel pipe. The open upper end of the thermowe11 was plugged with a 304L stainless steel nozzle plug in preparation for storage. The dissolver rests on a cradle on its railcar in an inclined position. This ensures that the mercury remains in the lower portion of the thermowell and is not in contact with the mechanical closure on the nozzle end of the thermowell.

A secondary containment barrier for mercury, should it leak from the thermowell, is provided by the dissolver itself. The dissolver is a 304L stainiess steel process vessel constructed from l-centimeter-thick plate and is approximately 2.7 meters in diameter. The dissolver is of all-welded construction and contains no drains or nozzle outlets in the bottom severa] feet of its lower section, which contains both thermowells.

The $304 \mathrm{~L}$ stainless steel used to contain the elemental mercury is both compatible with the waste itself and the storage environment. The potential for significant deterioration of either the primary or secondary containment barrier material before closure is considered to be negligible.

The dissolvers stored within the PUREX Storage Tunnels are not labeled as containing characteristic toxic mercury (D009) [WAC 173-303-090(8)(c)] . Procedures for labeling were not in place at the time of storage. Personnel access into the storage area for purposes such as labeling is not feasible because of the radiation levels and cannot be justified under ALARA guidelines. Based on ALARA, mixed waste presently within the PUREX Storage Tunnels will remain unlabeled. However, during future transfers of mixed waste into the PUREX Storage Tunnels the railcars will be labeled as specified by WAC 173-303-395(6) and WAC 173-303-630(3). 


\subsubsection{Containers Without Free Liquids That Do Not Exhibit Ignitability or Reactivity}

The total amount of lead in Tunnel Number 1 is approximately 230 kilograms. The total amount of lead present in Tunnel Number 2 at this time, through position 21 , is approximately 4,684 kilograms. Most lead is fully contained in a11-welded encasements of either carbon steel or $304 \mathrm{~L}$ stainless steel. The encasement serves as support, protection against mechanical damage, and protection of the lead from exposure to the environment.

Stored lead has been placed in burial boxes of appropriate size. The boxes provide secondary containment for the lead in the unlikely event the primary encasement shouid fail. Although boxes may be open on the top, the PUREX Storage Tunnels are enclosed; therefore, the containers are protected from the elements.

Both carbon steel and 304L stainless steel used to encase the lead are compatible with the waste and the storage environment. Significant deterioration of either the primary or secondary containment barrier materials before closure is not considered to be credible.

In the past, material that contains lead or that has encased lead attached was not labeled as containing characteristic toxic lead (D008) [WAC 173-303-090(8)], because the requirements were not yet on line. As stated in Section 4.2.1, personnel entry into the tunnel storage area for purposes of labeling would be inconsistent with ALARA guidelines. However, during future storage of material containing lead the railcars will be Tabeled in accordance with WAC 173-303-395(6) and WAC 173-303-630(3).

\subsubsection{Protection of Extremely Hazardous Waste in Containers}

The present amount of mixed waste stored in the PUREX Storage Tunnels is sufficient to characterize this material as extremely hazardous waste. Because the PUREX Storage Tunnels are enclosed totally, protective covering from the elements and from run-on is provided for the storage of extremely hazardous waste. Periodic inspection of the equipment stored in the PUREX Storage Tunnels is not feasible because of radiation levels in excess of 5 roentgen per hour. Safe management of this waste is based on the following considerations.

- The operation of the PUREX Storage Tunnels is passive, i.e., once a storage position is filled, the storage position remains undisturbed until closure.

- The extremely hazardous waste is compatible with its storage container and the storage environment. 
1 4.2.4 Prevention of Reaction of Ignitable, Reactive, and Incompatible

- The operation of the PUREX Storage Tunnels is passive; i.e., once a storage position is filled, the storage position remains undisturbed until closure.

- The silver nitrate is contained within large, heavy-walled stainless steel vessels that isolate the silver nitrate from contact with any combustibles that might be in the tunnels.

- The silver nitrate is dispersed over a large surface area on a ceramic packing substraight and is not conducive to build-up of heat that could lead to spontaneous combustion.

- Personnel access to the occupied areas of the tunnels is not permitted, thereby precluding activities that could present a fire hazard (e.g., smoking, flame cutting, welding, grinding, and other electrical activities).

Although ignitable waste storage units are required by WAC 173-303-395(1)(d) to have inspections conducted at least yearly by a fire marshall or professional fire inspector familiar with the requirements of the uniform fire code, the radiation levels within the PUREX Storage Tunnels make such inspections impractical. These inspections are not considered appropriate or necessary for the safe operation of the unit because of the nature of the ignitable waste and the means of storage. The rationale for operations associated with the PUREX Storage Tunnels is addressed further in a petition for rulemaking submitted to Ecology and the EPA (Freeberg 1989) in fulfillment of Hanford Federal Facility Agreement and Consent Order (Tri-Party Agreement) Milestone M-22-01 (Ecology et a1. 1995). 


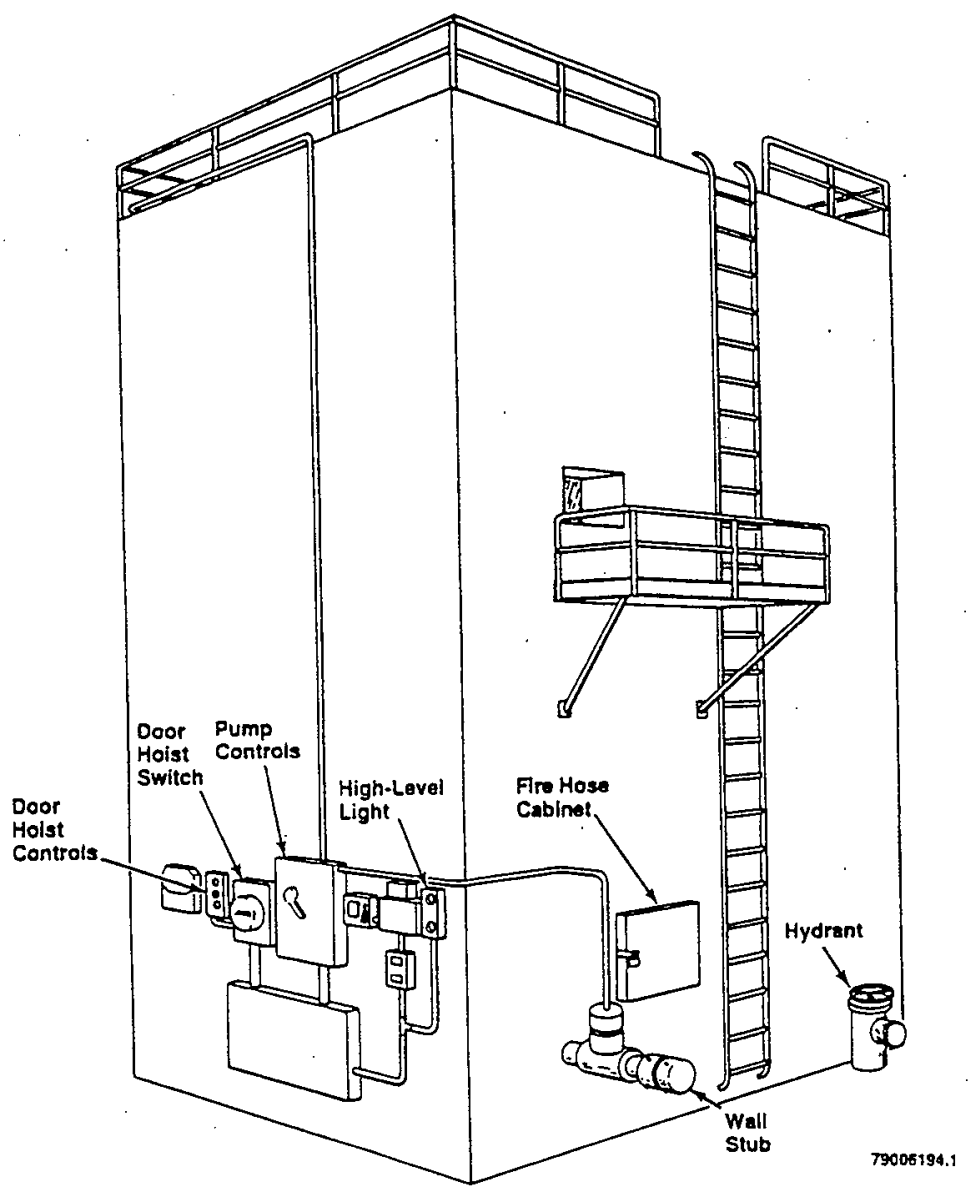

Figure 4-1. Water-Fillable Door Exterior (Tunnel Number 2). 


\section{THIS PAGE INTENTIONALLT LEET BLANK \\ d}


OOE/RL-90-24, Rev. 2

$11 / 95$

\section{CONTENTS}

5.0 GROUNDWATER MONITORING FOR LAND-BASED UNITS [D-10] ..... 5 5-1 5

$r^{x}$ 
DOE/RL-90-24, Rev. 2

$11 / 95$

This page intentionally left blank. 
DOE/RL-90-24, Rev. 2 $11 / 95$

\subsection{GROUNDWATER MONITORING FOR LAND-BASED UNITS [D-10]}

The PUREX Storage Tunnels are not operated as a dangerous waste surface impoundment, waste pije, land treatment unit, or a landfill as defined in WAC 173-303-645(1)(a). Therefore, groundwater monitoring is not required. 
DOE/RL-90-24, Rev. 2
$11 / 95$

This page intentionally left blank. 


\section{CONTENTS}

6.0 PROCEDURES TO PREVENT HAZARDS [Fj . . . . . . . . . . . . . . . . . 6-1

6.1 SECURITY $[F-1]$. . . . . . . . . . . . . . . . . 6-1

6.1 .1 Security Procedures and Equipment $[F-1 \mathrm{a}] \ldots \ldots+\ldots-1$

6.1.1.1 24-Hour Surveillance System . . . . . . . . . 6-1

6.1 .1 .2 Barrier and Means to Control Entry . . . . . 5-1

6.1 .1 .3 Warning Signs................ 6-1

6.1 .2 Watver $[F-1 b] . . . . . . . . . .66-1$

6.2 INSPECTION PLAN [F-2]................. 6-2

6.3 PREPAREDNESS AND PREVENTION REQUIREMENTS [F-3] . . . . . . $6-2$

6.3.1 Equipment Requirements $[\mathrm{F}-3 \mathrm{a}] . . . . . . .6-2$

6.3.1.1 Internal Communications.......... . 6-2

6.3.1.2 Externa! Communications.......... . 6-2

6.3.1.3 Emergency Equipment .. . . . . . . . . . 6-3

6.3.1.4 Water for Fire Control . . . . . . . . . . 6-3

6.3.2 Ais le Space Requirement $[F-3 b] . . . . . . .6-3$

6.4 PREVENTIVE PROCEDURES, STRUCTURES, AND EQUIPMENT [F-4] . . . $6-3$

6.4 .1 Unloading Operations . . . . . . . . . . . 6-3

6.4.2 Run-0ff .................... 6-3

6.4.3 Water Supplies............... . 6-4

6.4.4 Equipment and Power Failures .. . . . . . ...... . 6-4

6.4.4.1 Mitigation of the Effects of Equipment

Failure............... 6-. 6-

6.4.4.2 Mitigation of the Effects of Power

Failure............. . 6-5

6.4.5 Personnel Protection Equipment . . . . . . . . 6-5

6.5 PREVENTION OF REACTION OF IGNITABLE, REACTIVE, AND/OR

INCOMPATIBLE WASTE $[\mathrm{F}-5] . . . . . . . . . . . . .6$ 6-5 
$\mathrm{DOE} / \mathrm{RL}-90-24, \operatorname{Rev} \cdot 2$
$11 / 95$

This page intentionally left blank. 


\subsection{PROCEDURES TO PREVENT HAZARDS [F]}

This chapter discusses security; inspection schedules; preparedness and prevention requirements; preventative procedures, structures and equipment; and prevention of reaction of ignitable, reactive, and incompatible waste stored in the PUREX Storage Tunnels.

\subsection{SECURITY [F-1]}

The following sections describe the security measures, equipment, and warning signs used to control entry into the PUREX Storage Tunnels. Hanford Facility security measures are discussed in the General Information Portion (DOE/RL-91-28).

\section{1:1 Security Procedures and Equipment [F-1a]}

The following sections describe the 24-hour surveillance system, barrier, and warning signs used to provide security and control access to the PUREX Storage Tunnels.

6.1.1.1 24-Hour Surveillance System. The entire Hanford Facility is a controlled access area. For surveillance information refer to the General Information Portion (DOE/RL-91-28).

6.1.1.2 Barrier and Means to Control Entry. The PUREX Storage Tunnels are protected by the 200 East Area fence and building structures to enhance physical security. Visitors are required to be escorted. Personnel wishing to enter either storage tunnel must be qualified radiation zone workers and must obtain appropriate approval on a need-to-enter basis. Entry into either storage tunnel is made from the PUREX Plant compound or from outside the railroad tunne1. Actual access into the active portion, the storage area, of the storage tunnels can be made oniy through the north entry after the massive, water-fillable doors are raised. The water-fillable doors normally are ciosed and require PUREX Plant operations approval, as well as mechanical assistance, to open.

6.1.1.3 Warning Signs. Points of access to the PUREX Storage Tunnels are posted with a sign, printed in English, reading "OANGER-UNAUTHORIZED PERSONNEL KEEP OUT," or an equivalent legend, in black and red letters on a white background, in accordance with requirements of WAC 173-303-310(2)(a). In addition to these signs, the 200 East Area fence is posted with signs warning against unauthorized entry. The signs also are visible from all angles of approach, from a distance of at least 7.6 meters. 


\subsubsection{Waiver $[\mathrm{F}-1 \mathrm{~b}]$}

A waiver of the security procedures and equipment requirements for the PUREX Storage Tunnels is not requested. Therefore, the requirements of WAC 173-303-310(1)(a) and (b) are not applicable to the PUREX Storage Tunnels.

\subsection{INSPECTION PLAN [F-2]}

Because waste within the PUREX Storage Tunnels is inaccessible because of the levels of radiation present (levels that exceed 5 roentgen per hour in certain areas of the tunnels), inspection of the tunnel interior will not be performed. External inspections of the tunnels only will be performed annually. The inspection schedules and inspection reports will be maintained with the tunnel storage records. Inspection records will be maintained for a minimum of 5 years.

Information from inspections is recorded on inspection reports. The report forms are used to initiate corrective action if necessary. The following identifies types of inspections that occur at the PUREX Storage Tunnels.

- External surfaces of the PUREX Storage Tunnels are observed for evidence of structural deterioration. Tunnel subsidence, erosion of the earth cover, and vent stack damage are of primary concern. Abnormal conditions are recorded, evaluated, and corrective action initiated as necessary.

- The points of access to the PUREX Storage Tunnels are inspected to ensure warning signs (Section 6.1.1.3) are in place, visible, and legible. Abnormal conditions are recorded, evaluated, and corrective action will be initiated as necessary.

\subsection{PREPAREDNESS AND PREVENTION REQUIREMENTS [F-3]}

The following sections document the preparedness and prevention measures taken at the PUREX Storage Tunnels.

\subsubsection{Equipment Requirements [F-3a]}

The following sections describe the internal and external communications systems and emergency equipment required.

6.3.1.1 Internal Communications. The PUREX Storage Tunnels are not occupied and personnel entry is aliowed only on a very limited basis and under close supervision. Normal and emergency communications equipment (portable two-way radios) is available for use.

6.3.1.2 External Communications. Externat communications equipment for summoning emergency assistance from the Hanford Fire Department and/or 
DOE/RL-90-24, Rev. 2

$11 / 95$

1

emergency response teams are provided by two-way portable radios or other devices.

\subsubsection{Emergency Equipment. Equipment included in the emergency plan for} the PUREX Storage Tunnels is provided in Appendix 7A.

\subsubsection{Water for Fire Control. The fire hazard associated with the} operation of the PUREX Storage Tunnels. is considered to be very low because of the minimal amount of combustibles stored within the tunnels and the lack of an ignition source (Rambosek and Foster 1972). In the event of a fire in the storage area of the tunnels, the contingency plan will be activated. Because of the potential of the mixed waste stored within the tunnels to leach, the use of water for fire control will be avoided if possible. Reduction of the air supply to the storage area by isolation of the tunnel exhaust system should permit the fire to self-extinguish. Should the fire continue to propagate, heavy equipment and cranes will be called to the scene to cover areas of the tunnels that might collapse. Heavy equipment and cranes are readily available on the Hanford Facility at all times and generally are available for deployment to the scene of an emergency within I hour. In the event that a fire resulted in the collapse of the tunnels, a recovery $p$ lan will be developed in accordance with emergency response procedures included in Appendix $7 \mathrm{~A}$. The recovery $\mathrm{plan}$ will take into consideration plans, if any, for retrieval of the waste stored within the tunnel(s).

\subsubsection{Aisle Space Requirement [F-3b]}

Requirements for aisle space are not considered appropriate for the safe operation of the PUREX Storage Tunnels and were not included in design documents.

\subsection{PREVENTIVE PROCEDURES, STRUCTURES, AND EQUIPMENT [F-4]} equipment.

\subsubsection{Unloading Operations}

Operation of the PUREX Storage Tunnels does not involve the loading or unloading of dangerous waste. All loading and unloading operations are conducted at the PUREX Facility or other onsite units. Therefore, the requirements of WAC 173-303-806(4)(a)(viii)(A) are not applicable to the PUREX Storage Tunnels.

\subsubsection{Run-0ff}

The design of the PUREX Storage Tunnels included consideration and provisions for the control of run-off and run-on. Construction of both tunnels included the application of a moisture barrier before placement of the 
1

soil overburden. On Tunnel Number 1, 40.8-kilogram mineral surface roofing was applied to the external surfaces of the structural timbers (top and sides). The roofing material was nailed in place with an overlap of approximateiy 10 centimeters at al1 joints and seams. All interior and exterior steel surfaces of Tunnel Number 2 were coated with at least a 0.9 millimeter bituminous, solvent coal tar base, coating compound. The coating was applied using a two-coat system, with each coat not less than $0.45 \mathrm{millimeter}$, ensuring a total dry film thickness of not less than 0.9 millimeter.

The soil overburden covering the PUREX Storage Tunnels also is contoured to provide a sideslope of 2 (horizontal) to 1 (vertical). This construction serves to divert any seasonal or unanticipated run-on away from the storage area of the PUREX Storage Tunnels. For potential situations where a natural catastrophic event occurs, inspections of the tunnel sideslopes are conducted to ensure the contours remain in a condition that ensures proper run-off and continues to divert run-on away from the tunnel storage areas. Further discussion of the design of the PUREX Storage Tunnels is provided in Chapter 2.0.

Run-on at the PUREX Storage Tunnels is controlled by the design features. of the exterior of the tunnels that serve to divert run-on away from the interior of the tunnels. Additionally, all waste within the tunnels is stored well above the floor level on railcars. The control of run-on combined with the storage of all waste above the floor elevation provides adequate assurance that run-off will not occur at the PUREX Storage Tunnels.

\subsubsection{Water Supplies}

Water is supplied to the PUREX Storage Tunnels from the PUREX PIant. This water is used for the sole purpose of filling the water-fillable doors should it be determined necessary. There are no other sources or uses of water at the PUREX Storage Tunnels. The line that supplies water to the PUREX Storage Tunnels will be blanked and emptied during deactivation activities.

\subsubsection{Equipment and Power FaiTures}

The procedures, structures, and equipment used to mitigate the effects of equipment failure and power outage are described in the following sections.

\subsubsection{Mitigation of the Effects of Equipment Failure. Maintaining safe} storage of materiais in the PUREX Storage Tunnels is not contingent on continued operation of equipment. The operable equipment associated with the PUREX Storage Tunnels are the remote-controlled locomotive, the railcars, and the water-fillable door and ventilation system for Tunnel Number 2 . No operable equipment is associated with Tunne? Number 1, as this tunnel has been sealed and no longer receives dangerous waste. Backup or redundant systems are not provided for Tunnel Number 2, as failure of the equipment wouid not have the potential to result in a release of dangerous waste to the environment. There are no hazards associated with tunnel equipment failure. 
1 6.4.4.2 Mitigation of the Effects of Power Failure. Maintaining safe storage

2 of materials in the PUREX Storage Tunnels is not contingent on continued

3 supply of electrical power. Electrical power is required to operate the

4 water-fillable door and the ventilation fan in Tunnel Number 2. Back-up or

5 redundant ventilation systems are not provided as the system is operated only

6 to maintain air balance and provide secondary control of radioactive airborne

7 particulate. Power failure to Tunnel Number 2 would not have the potential to

8 result in the release of dangerous waste or radioactive material to the

9 environment. There are no hazards associated with the shutdown of the tunnel

ventilation system due to loss of electrical power.

\subsubsection{Personnel Protection Equipment}

Personnel entering the PUREX Storage Tunnels are required to wear special protective clothing and respiratory protection at all times because of the radioactive material stored in the PUREX Storage Tunneis. Protective clothing and full-face respirators with filters are considered to be sufficient protection from the dangerous waste stored within the PUREX Storage Tunnels. Personnel are trained and qualified in using the protective equipment and are checked routinely for mask fit.

\subsection{PREVENTION OF REACTION OF IGNITABLE, REACTIVE, AND/OR INCOMPATIBLE WASTE [F-5]}

There is no reactive or incompatible waste stored in the PUREX Storage Tunnels. The only ignitable waste stored within the tunnels is silver nitrate. The silver nitrate is present within the silver reactors (deposited on unglazed ceramic packing) stored in Tunnel Number 2 (Chapter 3.0, Table 3-1).

Although silver nitrate exhibits the characteristic of ignitability, it is contained within stainless steel vessels, stored on railcars above the floor level, and isolated from combustible materials and other dangerous waste. Additional measures to prevent reaction of the ignitable waste are not considered necessary. 
This page intentionally left blank. 


\section{CONTENTS}

7.0 CONTINGENCY PLAN $[\mathrm{G}] \ldots \ldots \ldots$ 7-1 . . . . . . . . . . . .

\section{APPENDIX}

11 7A UNIT-SPECIFIC CONTINGENCY PLAN FOR THE 218-E-14 AND
12 


$$
\text { DOE/RL-90-24, Rev. } 2
$$

$11 / 95$

This page intentionally left blank. 


\subsection{CONTINGENCY PLAN [G]}

The WAC 173-303 requirements for contingency $p$ lans are satisfied in the following documents: the Unit-Specific Contingency P7an for the 218-E-14 and 218-E-15 Storage Tunnels (Appendix 7A) and the Hanford Facility Contingency Plan [Attachment 4 of the Hanford Facility RCRA Permit (Dangerous Waste Portion)].

The unit-specific contingency plan document aiso serves to satisfy a broad range of other requirements [e.g., Occupational Safety and Health Administration standards (29 CFR 1910) and U.S. Department of Energy Orders]. Therefore, revisions made to portions of this contingency plan document that are not governed by the requirements of WAC 173-303 will not be considered a modification subject to review or approval by Ecology. 
This page intentionally left blank. 
DOE/RL-90-24, Rev. 2

$11 / 95$

\section{CONTENTS}

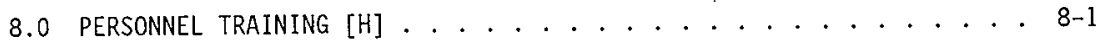

APPENDIX

8A DANGEROUS WASTE TRAINING PLAN FOR THE PUREX FACILITY . . . . . APP 8A12

13 
DOE/RL-90-24, Rev. 2

$11 / 95$

This page intentionally left biank. 


\subsection{PERSONNEL TRAINING [H]}

The training plan provided in Appendix $8 \mathrm{~A}$ discusses training requirements pertaining to the PUREX Storage Tunnels.

The training program is designed to be compliant with all applicable federal, state, and DOE-RL training requirements. The training program complies with requirements contained within WAC 173-303-330 for the development of a written dangerous waste training program. The training program is designed to prepare personnel to manage and maintain TSD units in a safe, effective, efficient, and environmentaliy sound manner. In addition to preparing employees to manage and maintain TSD units under normal conditions, the training program ensures that employees are prepared to respond in a prompt and effective manner should abnormal or emergency conditions occur. 


\section{DOE/RL-90-24, Rev. 2 \\ $11 / 95$}

This page intentionally left blank. 
DOE/RL-90-24, Rev. 2

$11 / 95$

1

CONTENTS

9.0 EXPOSURE INFORMATION REPORT .................. . . 9-1 
This page intentionally left blank. 


\subsection{EXPOSURE INFORMATION REPORT}

The PUREX Storage Tunnels do not store, treat, or dispose of hazardous waste in a surface impoundment or a 1 andfill as defined in 40 CFR 270.10 and

RCRA, Section 3019. Therefore, exposure information is not required. 
DOE/RL-90-24, Rev. 2

$11 / 95$

This page intentionally left blank. 
DOE/RL-90-24, Rev. 2

$11 / 95$

\section{CONTENTS}

10.0 WASTE MINIMIZATION $[\mathrm{D}-9] \ldots \ldots \ldots$ 10-1

6

7 
$\mathrm{DOE} / \mathrm{RL}-90-24$, Rev. 2

$11 / 95$

This page intentionally left blank. 
DOE/RL-90-24, Rev. 2

$11 / 95$

\subsection{WASTE MINIMIZATION [D-9]}

To fulfill the requirements of 40 CFR $264.73(\mathrm{~b})(9)$, a certification form that the PUREX Storage Tunnels have a waste minimization/pollution prevention program in $\mathrm{place}$ will be entered, annually, into the PUREX Storage Tunnels operating record. 
DOE/RL-90-24, Rev. 2

$11 / 95$

This page intentionally left blank. 


\section{CONTENTS}

11.0 ClOSURE AND finanCial ASSURANCE [I] . . . . . . . . . . . . . . 11-1

11.1 IN SITU DISPOSAL OPTIONS .................. . . . . . .

11.1.1 Backfilling the Tunnels with Grave . . . . . . . 11-1

11.1.2 Injecting the Tunnels with Grout . . . . . . . . . . 11-1

11.1.3 Combination of Grout Injection and

Backfilling .................... 11-2

11.2 RETRIEVAL/CLEAN ClOSURE OPTIONS . . . . . . . . . . . . 11-2

11.2.1 Retrieval and Disposal in the PUREX Plant . . . . . 11-2

11.2.2 Retrieval and Physical Processing (size reduction)

in the PUREX P-7ant and Subsequent Disposal . . . 11-2

11.2.3 Construction of a New Facility for Retrieval,

Processing, and Treatment of Equipment for

Disposa? 
DOE/RL-90-24, Rev. ?

$11 / 95$

This page intentionally left blank. 
$\mathrm{DOE} / \mathrm{RL}-90-24$, Rev. 2

$11 / 95$

\subsection{CLOSURE AND FINANCIAL ASSURANCE [I]}

Closure of the PUREX Storage Tunnels requires coordination with closure of the PUREX Plant to ensure a cost effective closure for both units. In addition, the highly radioactive nature of the mixed waste located within the PUREX PIant and PUREX Storage Tunnels precludes the determination of the type of treatment and/or disposition of the waste at this time.

The PUREX Storage Tunnels will be managed as a RCRA storage unit unti] closure can be coordinated with the final closure plan for the PUREX Plant. The PUREX Storage Tunnels closure plan will be submitted after any required National Environmental Policy Act of 1969 documentation and land usage agreements, which initiate disposition and aid in identifying or developing nécessary disposition activities, have been adopted.

The PUREX Storage Tunnels closure plan will be written to meet the requirements of WAC 173-303-140 and WAC 173-303-610. This closure plan might consider but will not be limited to the following options for either in situ disposal or retrieval/clean closure of this unit.

\subsection{IN SITU DISPOSAL OPTIONS}

This closure plan might consider but will not be limited to the following options for in situ disposal of waste in this unit.

\subsubsection{Backfilling the Tunnels with Gravel}

This option could involve backfilling the tunnels with gravel to eliminate void space and prevent ground subsidence. A modified commercially available centrifugal rock throwing device could be placed in newly constructed risers evenly spaced along each tunnel roof. Fill material could be supplied and dispersed into the tunnels by automated controls. Following the fill process, all equipment could be removed from the tunnel roofs and all means of access to the tunnels could be permanently sealed. Final activities could involve the construction of a final surface barrier that meets RCRA landfill cover requirements to prevent water from leaching mixed waste contained in the tunnels.

\subsubsection{Injecting the Tunnels with Grout}

This option could involve the injection of grout material into each tunnel to stabilize and immobilize contained materials and prevent ground subsidence. A grout injector could be alternateiy placed in newly constructed risers evenly spaced along each tunnel roof. Grout material could be supplied and dispersed into the tunnels by automated controls. The grout material could be injected in lifts to accommodate curing and heat dissipation normaliy associated with the use of this type of material. Final activities could involve the construction of a final surface barrier that meets RCRA 1andfill 
cover requirements to prevent water from leaching mixed waste contained in the tunnels.

\subsubsection{Combination of Grout Injection and Backfilling}

This options combines grout injection with gravel backfilling similar to the processes discussed previous $7 y$. Grout could be injected first to fill void spaces under the railcars and provide a basal structure. Gravel could be dispersed to fill remaining void space and prevent ground subsidence. Final activities could involve the construction of a final surface barrier that meets RCRA landfiTl cover requirements to prevent water from leaching mixed waste contained in the tunnels.

\subsection{RETRIEVAL/CLEAN CLOSURE OPTIONS}

This closure $p l$ an might consider but will not be limited to the following options for retrieval/clean closure of this unit.

\subsubsection{Retrieval and Disposal in the PUREX Plant}

Railcars stored in both tunnels could be remotely retrieved one at a time and moved beneath the horizontal door of the railroad tunnel extension for remote viewing, and if possible, characterization. Transfer procedures could be initiated to move waste material from the railcars to the PUREX Plant canyon deck area. Following transfer of the waste material, the railcars could be decontaminated and removed for final disposition at other onsite units. Final disposition of the waste transferred to the canyon deck area could be in accordance with PUREX Plant closure documentation. The PUREX Storage Tunnels could be closed after submittal and implementation of a PUREX Storage Tunnels closure plan in conjunction with PUREX Plant closure documentation. The PUREX Storage Tunnels closure plan will detail verification sampling and analysis to be performed as a part of closure activities.

\subsubsection{Retrieval and Physical Processing (size reduction) in the PUREX Plant and Subsequent DisposaT}

Retrieval of waste material stored in the tunnels could be similar to that described in the previous section. Once the waste material was transferred to the PUREX Plant canyon deck area, characterization and size reduction of waste material could proceed. An area located on the canyon deck or in a process cell could be modified to include all necessary equipment to perform characterization and size reduction activities. Size reduction could be performed through various technologies that include, but are not limited to, flame cutting, water jet cutting, sawing, or other technologies. Final disposition of the processed waste material either onsite or offsite could be in accordance with regulations and procedures in place at that time. The PUREX Storage Tunnels could be closed after submittal and implementation of a 
I PUREX Storage Tunnels cTosure plan in conjunction with PUREX Plant closure 2 documentation. The PUREX Storage Tunnels closure plan wiil detail

3 verification sampling and analysis to be performed as a part of closure 4 activities.

\subsubsection{Construction of a New Facility for Retrieval, Processing, and Treatment of Equipment for Disposal}

This option involves the construction of a new unit that is either mobile or stationary to excavate, retrieve, and treat waste material stored in the tunnels. The unit could be constructed in a manner consistent with the retrieval and handling requirements for large, contaminated waste material. Following retrieval, the waste material could be treated in accordance with final onsite or offsite disposition requirements identified at such time. The excavated tunnels could have a temporary surface barrier placed in position until verification and sampling analysis could be performed as a part of closure activities to be performed in conjunction with PUREX Plant closure. 
DOE/RL-90-24, Rev. 2

$11 / 95$

This page intentionally left blank. 
3
4 12.0 REPORTING AND RECORDKEEPING . . . . . . . . . . . . . . . . . 12-1 5 
D0E/RL-90-24, Rev. 2

$11 / 95$

This page intentionally left blank. 


\subsection{REPORTING AND RECORDKEEPING}

Reports and records applicable to the PUREX Storage Tunnels are summarized in Chapter 12.0, Table 12-1; of the General Information Portion (DOE/RL-91-28). 
DOE/RL-90-24, Rev. 2

$11 / 95$

1

2

3

4

5

This page intentionally left blank. 
DOE/RL-90-24, Rev. 2

$11 / 95$

\section{CONTENTS}

13.0 OTHER FEderal AND STATE LAWS $[\mathrm{J}] \ldots$. . . . . . . . . . . . . . 5 
DoE/RL-90-24, Rev.. 2

$11 / 95$

1

2

3

4

This page intentionally left blank. 


\subsection{OTHER FEDERAL AND STATE LAWS [J]}

2

3

4 Other federal and state laws and local requirements applicable to the

5 PUREX Storage Tunnels (Atomic Energy Act of 1954, Clean Air Act of 1977, Toxic

6 Substances Contro7 Act of 1976, and the Federa7 Insecticide, Fungicide, and

7 Rodenticide Act of 1975) are discussed in Chapter 13.0 of the Genera?

8 Information Portion (DOE/RL-91-28). 
This page intentionally left blank. 
DOE/RL-90-24, Rev. 2

$11 / 95$

\section{CONTENTS}

2

3

4. 14.0 PART B CERTIFICATION [K] . . . . . . . . . . . . . . . . . . . 14-1 5 
DOE/RL-90-24, Rev. 2 $11 / 95$

This page intentionally left blank. 


$$
\begin{array}{r}
\text { DOE/RL-90-24-Rev. } 2 \\
11 / 95
\end{array}
$$

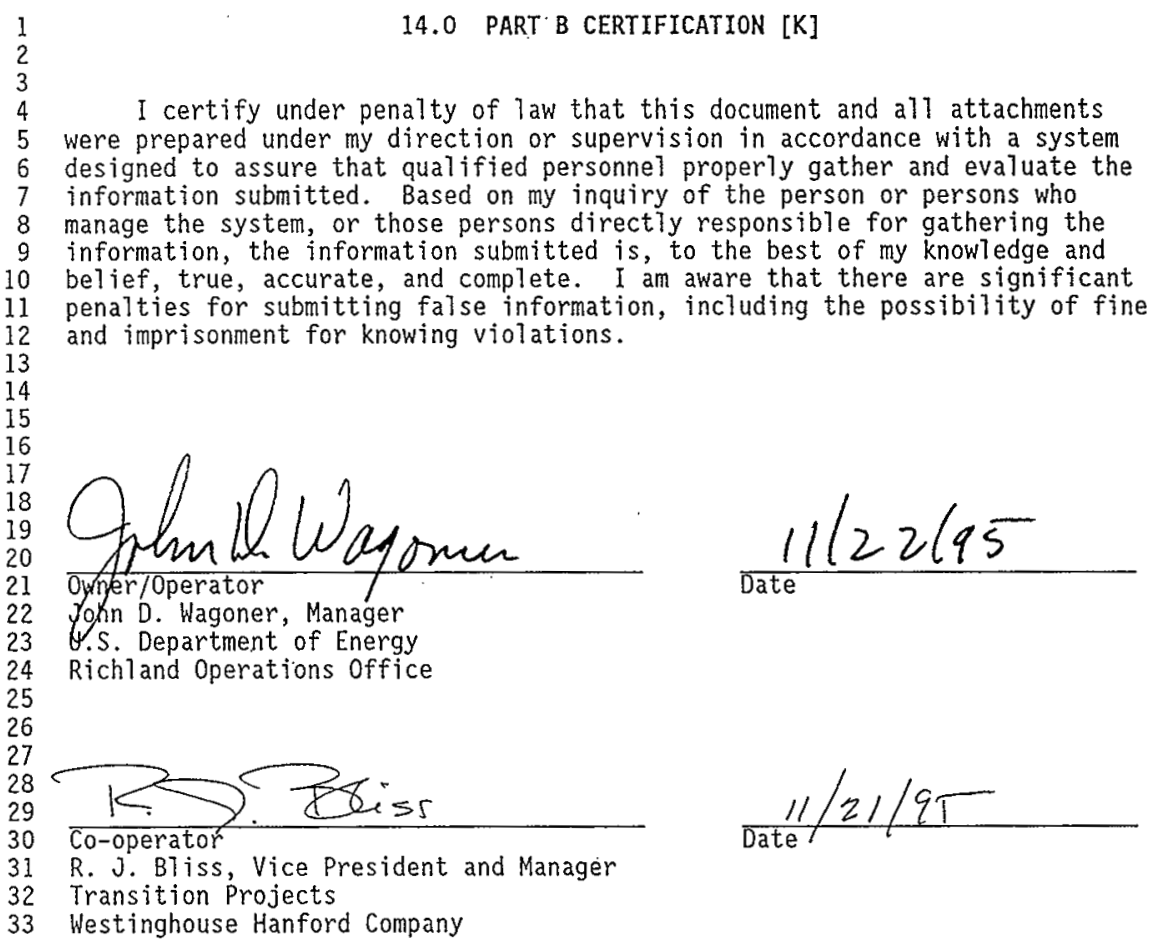

14.0 PART B CERTIFICATION [K]

R. J. BT iss, Vice President and Manager Transition Projects Westinghouse Hanford Company

951109.1119

14-1 


$$
\begin{array}{r}
\mathrm{DOE} / \mathrm{RL}-90-2 \overrightarrow{4,} \text { Rev. } 2 \\
11 / 95
\end{array}
$$

This page intentionally left blank. 
DOE/RL-90-24, Rev. 2

$11 / 95$

\section{CONTENTS}

15.0 REFERENCES . . . . . . . . . . . . . . . . . . . . . 15-1 5 


\section{DOE/RL-90-24, Rev. 2 \\ $11 / 95$}

This page intentionally left blank. 
D0E/RL-90-24, Rev. 2 $11 / 95$

\subsection{REFERENCES}

AASHTO, 1983, Standard Specification for Highway Bridges, AASHTO-HS-20-44 American Association of State Highway Transportation Officials, Washington, D.C.

Conway, R. A., 1982, Environmental Risk Analysis for Chemica7s, Van Nostrand Reinhold Environmental Engineering Series, Van Nostrand Reinhold Company, New York, New York.

DOE-RL, 1988, Hanford Facility Dangerous Waste Part A Permit Application, Volumes 1 through 3, DOE/RL 88-21, U.S. Department of Energy, Richland Operations Office, Richland, Washington, updated periodically.

DOE/RL-91-28, Hanford Facility Dangerous Waste Permit Application, General Information Portion, Revision 1, U.S. Department of Energy, Richland Operations Office, Richland, Washington.

Ecology, 1995, State of Washington Part B Permit Application Requirements, Washington State Department of Ecology, 0lympia, Washington.

Ecology, EPA, and DOE, 1995, Hanford Federal Facility Agreement and Consent Order, Washington State Department of Ecology, U.S. Environmenta]

Protection Agency, and U.S. Department of Energy, Olympia, Washington.

Freeberg, R. D., 1989, Proposed Petitions for Rulemaking Changes for Interim Milestone M-22-01, Correspondence dated September 27, 1989, Number 8955715, U.S. Department of Energy, Rich1and Operations Office, Richland, Washington.

Hand, F. R. and V. J. Stephens, 1991, An Evaluation of the Structural Integrity of PUREX Storage Tunnel \#1, Los Alamos Technical Associates, Inc., Los Alamos, New Mexico.

Rambosek, A. J. and R. K. Foster, 1972, Fire and Explosion Hazard Evaluation Waste Storage Facility AEC Hanford Operations, Mining Enforcement and Safety Administration, Denver Technical Support Center, Denver, Colorado.

Silvan, G. R., 1980, Structural Evaluation of the PUREX No. I Burial Tunne7, RHO-CD-1076, Rockwell Hanford Operations, Richland, Washington. 
DOE/RL-90-24, Rev. 2

11/95

This page intentionally left blank. 
DOE/RL-90-24, Rev. 2

$11 / 95$

\section{APPENDICES}

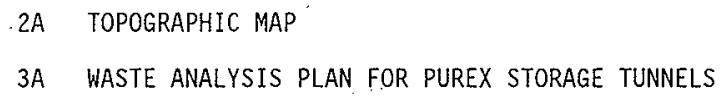

8A DANGEROUS WASTE TRAINING PLAN FOR THE PUREX FACILITY 
DOE/RL-90-24, Rev. 2

I1/95

1

2.

3

5

This page intentionally left blank. 
DOE/RL-90-24, Rev. 2

$11 / 95$

\section{APPENDIX 2A}

TOPOGRAPHIC MAP 
1

2

3

4

$5 \quad H-2-79998$
APPENDIX 2A

TOPOGRAPHIC MAP PUREX STORAGE TUNNELS 


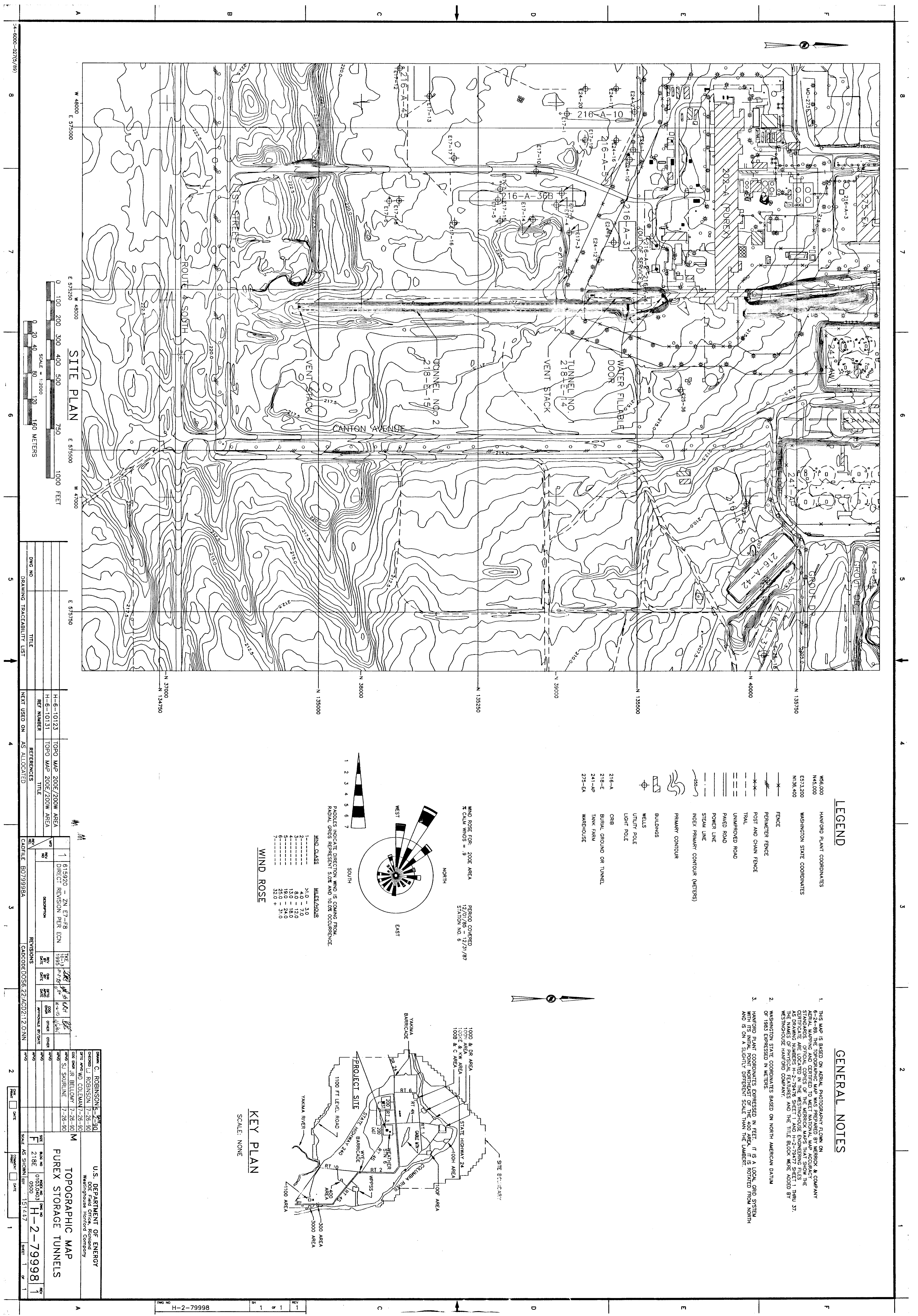




\section{DOE/RL-90-24, Rev. 2 \\ $11 / 95$}

\section{APPENDIX $3 \mathrm{~A}$}

WASTE ANALYSIS PLAN FOR PUREX STORAGE TUNNELS 
DOE/RL-90-24, Rev. 2

$11 / 95$

This page intentionally left blank. 
WHC-SD-EN-WAP-007, Rev. I

\section{CONTENTS}

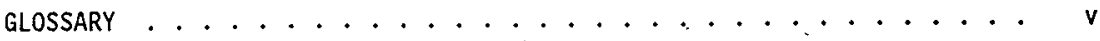

METRIC CONVERSION CHART ....................... vi

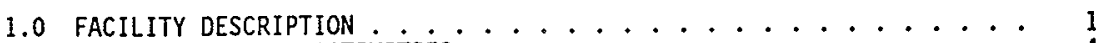

1.1 PROCESS AND ACTIVITIES $4 . . . .44$

1.2 PHYSICAL CHARACTERIZATION OF MATERIAL TO BE STORED $\cdot . \cdots 4$

1.3 IDENTIFICATION/CLASSIFICATION AND QUANTITIES OF HAZARDOUS

2.0 WASTE ANALYSIS PARAMETERS ............... 5

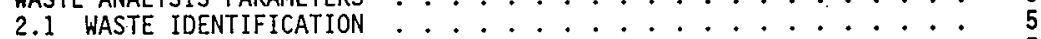

2.1 .1 Lead . . . . . . . . . . . . . . . . 5

2.1 .2 Mercury ................ 6

2.1 .3 silver....................... 7

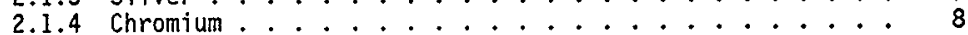

2.1 .5 Cadmium .................. 8

2.1 .6 Identification of Incompatible Waste........99

2.1.7 0perational Considerations .......... 9

2.2 PARAMETER AND RATIONALE SELECTION PROCESS .......... 9

2.2.1 Discarded Chemical Products ............ 9

2.2 .2 Dangerous Waste Sources ........... 10

2.2 .3 Dangerous Waste Characteristics ........ 10

2.2 .4 Dangerous Waste Criteria ........... 11

2.3 RATIONALE FOR PARAMETER SELECTION ................ II

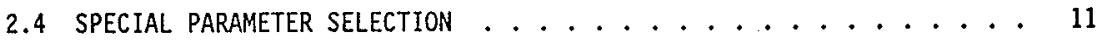

3.0 SELECTION OF SAMPLING PROCEDURES .............. 11

3.1 SAMPLING STRATEGIES . . . . . . . . . . . . . . 12

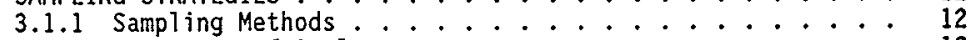

3.1 .2 Frequency of Analyses ...................... 12

3.2 SELECTION OF SAMPLING EQUIPMENT ........... 13

3.3 MAINTAINING AND DECONTAMINATING FIELD EQUIPMENT . ...... 13

3.4 SAMPLE PRESERVATION AND STORAGE . ......... 13

3.5 QUALITY ASSURANCE/QUALITY CONTROL PROCEDURES ........ 13

3.6 HEALTH AND SAFETY PROTOCOLS . . . . . . . . . . 14

4.0 LABORATORY SELECTION AND TESTING AND ANALYTICAL METHODS $\ldots \ldots \ldots 14$

4.1 LABORATORY SELECTION ......................... 14

4.2 TESTING AND ANALYTICAL METHODS $\ldots \ldots 14$

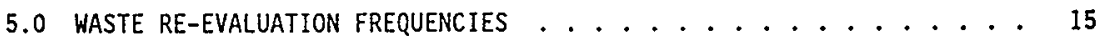

6.0 SPECIAL PROCEDURAL REQUIREMENTS ................... 15

6.1 PROCEDURES FOR RECEIVING WASTES GENERATED OFFSITE $\ldots 15$

6.2 PROCEDURES FOR IGNITABLE, REACTIVE, AND INCOMPATIBLE WASTE $: 15$ 
16.3 PROVISIONS FOR COMPLYING WITH LAND DISPOSAL RESTRICTION

6.4 DEVIATIONS FROM THE REQUIREMENTS OF THIS PLAN $\cdots \cdots \cdots$

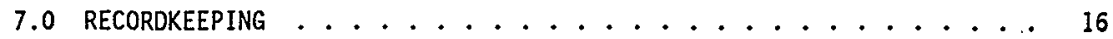

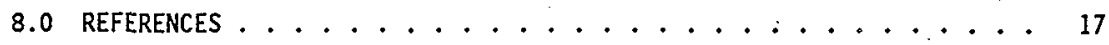

TABLE

12

1. PUREX Storage TunneTs Inventory ............... T-1.1 
WHC-SD-EN-WAP-007, ReV. 1

4

5

6

7$$
8
$$$$
9
$$$$
10
$$$$
11
$$$$
12
$$

13

14

15

16

17

18 WAC

19 WAP

EHW

EPA

$\mathrm{pH}$

TSO

WAC
WAP

\section{GLOSSARY}

ALARA

as low as reasonably achievable

ECOLOGY

PUREX

QA/QC
Washington State Department of Ecology extremely hazardous waste U.S. Environmental Protection Agency

negative logarithm of the hydrogen-ion concentration plutonium-uranium extraction quality assurance and quality control

treatment, storage, and/or disposal

Washington Administrative Code waste analysis plan 


\section{METRIC CONVERSION CHART}

The following conversion chart is provided to the reader as a tool to aid in conversion.

Into metric units

\begin{tabular}{|c|c|c|c|c|c|}
\hline If you know & $\begin{array}{l}\text { MuTtiply } \\
\text { by }\end{array}$ & To get & If you know & $\begin{array}{c}\text { Multiply } \\
\text { by }\end{array}$ & To get \\
\hline \multicolumn{3}{|c|}{ Length } & \multicolumn{3}{|c|}{ Length } \\
\hline inches & 25.40 & millimeters & millimeters & 0.0393 & inches \\
\hline inches & 2.54 & centimeters & centimeters & 0.393 & inches \\
\hline feet & 0.3048 & meters & meters & 3.2808 & feet \\
\hline yards & 0.914 & meters & meters & 1.09 & yards \\
\hline miles & 1.609 & kilometers & kilometers & 0.62 & miles \\
\hline \multicolumn{3}{|c|}{ Area } & \multicolumn{3}{|c|}{ Area } \\
\hline $\begin{array}{l}\text { square } \\
\text { inches }\end{array}$ & 6.4516 & $\begin{array}{l}\text { square } \\
\text { centimeters }\end{array}$ & $\begin{array}{l}\text { square } \\
\text { centimeters }\end{array}$ & 0.155 & $\begin{array}{l}\text { square } \\
\text { inches }\end{array}$ \\
\hline square feet & 0.092 & $\begin{array}{l}\text { square } \\
\text { meters }\end{array}$ & $\begin{array}{l}\text { square } \\
\text { meters }\end{array}$ & 10.7639 & $\begin{array}{l}\text { square } \\
\text { feet }\end{array}$ \\
\hline $\begin{array}{l}\text { square } \\
\text { yards }\end{array}$ & 0.836 & $\begin{array}{l}\text { square } \\
\text { meters }\end{array}$ & $\begin{array}{l}\text { square } \\
\text { meters }\end{array}$ & 1.20 & $\begin{array}{l}\text { square } \\
\text { yards }\end{array}$ \\
\hline $\begin{array}{l}\text { square } \\
\text { miles }\end{array}$ & 2.59 & $\begin{array}{l}\text { square } \\
\text { kilometers }\end{array}$ & $\begin{array}{l}\text { square } \\
\text { kilometers }\end{array}$ & 0.39 & $\begin{array}{l}\text { square } \\
\text { miles }\end{array}$ \\
\hline acres & 0.404 & hectares & hectares & 2.471 & acres \\
\hline \multicolumn{3}{|c|}{ Mass (weight) } & \multicolumn{3}{|c|}{ Mass (weight) } \\
\hline ounces & 28.35 & grams & grams & 0.0352 & ounces \\
\hline pounds & 0.453 & kilograms & kilograms & 2.2046 & pounds \\
\hline short ton & 0.907 & metric ton & metric ton & 1.10 & short ton \\
\hline \multicolumn{3}{|c|}{ Volume } & \multicolumn{3}{|c|}{ Volume } \\
\hline $\begin{array}{l}\text { fluid } \\
\text { ounces }\end{array}$ & 29.57 & milliliters & milliliters & 0.03 & $\begin{array}{l}\text { fluid } \\
\text { ounces }\end{array}$ \\
\hline quarts & 0.95 & liters & Titers. & 1.057 & quarts \\
\hline gallons & 3.79 & Jiters & Titers & 0.26 & gallons \\
\hline cubic feet & 0.03 & $\begin{array}{l}\text { cubic } \\
\text { meters }\end{array}$ & $\begin{array}{l}\text { cubic } \\
\text { meters }\end{array}$ & 35.3147 & cubic feet \\
\hline cubic yards & 0.76 & $\begin{array}{l}\text { cubic } \\
\text { meters }\end{array}$ & $\begin{array}{l}\text { cubic } \\
\text { meters }\end{array}$ & 1.308 & $\begin{array}{l}\text { cubic } \\
\text { yards }\end{array}$ \\
\hline \multicolumn{3}{|c|}{ Temperature } & \multicolumn{3}{|c|}{ Temperature } \\
\hline Fahrenheit & $\begin{array}{l}\text { subtract } \\
32 \text { then } \\
\text { multipiy } \\
\text { by } 5 / 9 \text { ths }\end{array}$ & Celsius & Celsius & $\begin{array}{l}\text { multiply } \\
\text { by } \\
9 / 5 \text { ths, } \\
\text { then add } \\
32\end{array}$ & Fahrenheit \\
\hline
\end{tabular}

Source: Engineering Unit Conversions, M. R. Lindeburg, PE., Second Ed., 1990, Professional Publications, Inc., Be]mont, California. 


\subsection{FACILITY DESCRIPTION}

This waste analysis plan (WAP) has been prepared for the Hanford Facility, PUREX Storage Tunnels, Richland, Washington, for the management of mixed waste. This HAP applies to all mixed waste (containing both radioactive and dangerous components) regulated by Washington Administrative Code (WAC) 173-303 that is transferred to and/or contained in the PUREX Storage Tunnels.

The PUREX Storage Tunnels are permitted as a miscellaneous unit under WAC 173-303-680. The bulk of the waste stored in the PUREX Storage Tunnels is not placed in a typical container; rather, this waste is placed on a portable device (railcar) that is used as a storage platform. In general, the dangerous waste stored in the PUREX Storage Tunnels is encased or contained within carbon or stainless steel plate, pipe, or vessels. Therefore, the mixed waste normally is not exposed to the tunnel environment.

The PUREX Facility, located in the 200 East Area, consists of two separate treatment, storage, and/or disposal (TSD) units, the PUREX Plant (202-A Building) and the PUREX Storage Tunnel-s. Access to the PUREX Storage Tunnels is by means of the railroad tunnel.

The PUREX Storage Tunnels branch off from the railroad tunnel and extend southward from the east end of the PUREX PIant. The tunnels are used for storage of mixed waste from the PUREX Plant and from other onsite sources. Each storage tunnel is isolated from the railroad tunnel by a water-fillable shielding door. There are no electrical utilities, water lines, drains, fire detection or suppression systems, radiation monitoring, or communication systems provided inside the PUREX Storage Tunnels.

Material selected for storage is loaded on railcars modified to serve as both transport and storage platforms. Normally, a remote-controlled, battery-powered locomotive is used to position the rajlcar in the storage tunnel. In the past and possibly in the future, other remote movers, e.g., standard locomotive with a string of railcar spacers, power wanch, etc., have or could be used to position a railcar into the tunnel or to withdraw a car from the tunnel. The railcar storage positions are numbered sequentially, commencing with Position 1 that abuts the railstop bumper at the south end of each tunnel. Position 2 is the location of the railcar that abuts the railcar in Position 1 and so forth. The railcars and material remain in the storage tunnel until retrieval is required. Each railcar is retrievable; however, because the railcars are stored on a single, dead-end railroad track, the railcars can be removed only in reverse order (i.e., last in, first out).

Construction of Tunnel Number 1 was completed in 1956 and consists of three areas: the water-fillable door, the storage area, and the vent shaft. The water-fillable door is located at the north end of Tunnel Number 1 and separates the storage tunnel from the PUREX railroad tunnel. The door is 7.5 meters high, 6.6 meters wide, and 2.1 meters thick, and is constructed of 1.3 centimeter steel plate. The door is hollow so that the door can be filled with water to act as a radiation shield when the door is in the down (closed) 
1 position. If the door is filled with water, the water must be pumped from the

2 door before the door can be raised.

3

Above the door is a reinforced concrete structure into which the door is raised to open the tunnel. Electric hoists used for opening and closing the door are located on the top of this concrete structure.

The storage area is that portion of the tunnel that extends southward from the water-fillable door. Inside dimensions of Tunnel Number 1 are 109.1 meters long, 6.7 meters high, and 5.9 meters wide. Ceiling and walls are 35.6 centimeters thick and constructed of 30.5 - by 35.6 -centimeter creosote pressure-treated Douglas fir timbers arranged side by side. The first 30.5 meters of the east wall are constructed of 0.9 -meter-thick reinforced concrete. A 40.8-kilogram mineral-surface roofing material was used to cover the exterior surface of the timbers before placement of 2.4 meters of earth fill. The earth cover serves as protection from the elements and as radiation shielding. The timbers that form the walls rest on reinforced concrete footings 0.9 meter wide by 0.3 meter thick. The floor consists of a railroad track laid on a gravel bed. The space between the ties is filled to top-of-tie with gravel ballast. The tracks are on a 1.0 percent downward slope to the south to ensure that the railcars remain in their storage position. A railcar bumper is located 2.4 meters from the south end of the tracks to act as a stop. The capacity of the storage area is eight, 12.8-meter-long railcars.

In June 1960, the first two railcars were loaded with a single, approximately 12.5-meter-1ong, failed separation column and placed in Tunnel Number 1. Between June 1960 and January 1965, six more railcars were placed in Tunnel Number 1, filling the tunnel. After the last car was placed in the northern-most storage position (Position 8 ), the water-fillabie door was closed, filled with water, and deactivated electrically.

Construction of Tunne] Number 2 was started and completed in 1964. Like Tunnel Number 1, Tunnel Number 2 consists of three functional areas: the water-fillable door, the storage area, and the vent shaft. Construction of Tunne] Number 2 differs from that of Tunnel Number 1 as follows.

- A combination of steel and reinforced concrete was used in the construction of the storage area for Tunnel Number 2 rather than wood timbers, as used in Tunnel Number 1.

- Tunnel Number 2 is longer, having a storage capacity of five times that of Tunnel Number 1 .

- The floor of Tunnel Number 2, outboard of the railroad ties, slopes upward to a height of approximately 1.8 meters above the railroad bed, whereas the floor in Tunnel Number 1 remains flat all the way out to the side walls.

- The railroad tunnel approach to Tunnel Number 2 angles eastward then angles southward to parallel Tunnel Number 1. The approach to Tunnel Number 1 is a straight extension southward from the PUREX Plant. 
WHC-SD-EN-WAP-007, Rev. 1

Center-line to center-line distance between the two tunnels is approximately 18.3 meters.

The physical structure of the water-fillable door at the north end of Tunnel Number 2 essentialiy is identical to the water-fillable door for Tunnel Number 1 . The water-fillable door for Tunnel Number 2 is approximately 57.9 meters south and 18.3 meters east of the water-fillable door for Tunnel Number 1. As of February 1995, the door is empty and there are no plans to fill it.

The storage area of Tunnel Number 2 is that portion of the tunnel extending southward from the water-fillable door. Construction of this portion of Tunne] Number 2 consists of a 10.4-meter diameter, steel ( 0.5 centimeter plate), semicircular-shaped roof, supported by internal I-beam wales attached to external, reinforced concrete arches. The concrete arches are 0.4 meter thick and vary in width from 0.4 to 1.8 meters. The arches are spaced on 4.8-meter centers. This semicircutar structure is supported on reinforced concrete grade beams approximately 1.8 meters wide by 1.2 meters thick (one on each side) that run the full length of Tunnel Number 2 . The interior and exterior surfaces of the steel roof are coated with a bituminous coating compound to inhibit corrosion. The entire storage area is covered with 2.4 meters of earth fill to serve as radiation shielding.

The nominat inside dimensions of Tunnel Number 2. are 514.5 meters long, 7.9 meters high, and 10.4 meters wide. However, because of the arch-shaped cross-section of Tunnel Number 2 and entry clearance at the water-fillable door, the usable storage area (width and height above top-of-rail) is 6.7 meters high and 5.8 meters wide, the same dimensions as for Tunnel Number 1 . The floor consists of a railroad track laid on a gravel bed. The space between ties is filled to top-of-tie with gravel ballast. Commencing at the ends of the 2.4-meter-long ties, the earth floor is sloped upward on a 1 (vertical) to $11 / 2$ (horizontal) grade. The tracks are on a $1 / 10$ of. 1 percent downgrade slope to the south to ensure the railcars remain in their storage position. A railcar bumper is located 2.4 meters from the south end of the tracks to act as a stop. The capacity of the storage area is 40 , 12.8-meter-long railcars.

The first railcar was placed in storage in December 1967. As of February 1995, 21 railcars have been placed in Tunnel Number 2.

The only free-liquid dangerous waste stored in the tunnels is mercury. The mercury is contained within thick-walled 0.8 centimeter thermowells constructed from 7.6 centimeter Schedule $80,304 \mathrm{~L}$ stainless steel pipe. The top of the thermowell is closed with a $304 \mathrm{~L}$ stainless steel nozzle plug with a metal-to-metal seal. The amount of mercury per thermowell is less than 1.7 liters.

Other 1iquid containers, such as large discarded process tanks or vessels, are stored in the PUREX Storage Tunnels. The containers in storage are empty [per WAC 173-303-160(2)(a)]. Prior to storage, vessels will be flushed and the final rinsate sampled and analyzed to verify that the residual heet is not a dangerous waste. 
The only stored dangerous waste that is either reactive or ignitable is silver nitrate in the silver reactors, which is designated as ignitable (D001) [WAC 173-303-090(5)]. The potential for ignition is considered to be negligible because this material is dispersed on ceramic packing and is physically isolated from contact with any combustible. material or ignition source.

\subsection{PROCESS AND ACTIVITIIES}

The function of the PUREX Tunnels is to store mixed waste until the waste can be processed for final disposal. When waste is to be placed in the storage tunnels, a work plan, describing the overall transfer activities and a storage tunnel checklist are prepared. The work plan and storage tunnel checklist are routed for review and concurrence by key personnel and forwarded to management for approval.

\subsection{PHYSICAL CHARACTERIZATION OF MATERIAL TO BE STORED}

Physical characterization of waste includes an evaluation of the following physical properties:

- Length, width, and height

- Gross weight and volume

- Preferred orientation for transport and storage

- Presence of dangerous waste constituents.

Information sources used in physical characterization include equipment fabrication and installation drawings, operational records, and process knowledge. Physical characterization provides information necessary to appropriately describe the waste material. Such information also is used to design and fabricate, if required, supports on the railcar.

Before removal from service, the equipment could be flushed to minimize loss of products, to reduce radioactive contamination, and to reduce dangerous waste constituents present in a residual heel to nonregulated levels. If equipment is flushed, analys is of the rinsate is used to determine when these goals have been achieved.

\subsection{IDENTIFICATION/CLASSIFICATION AND QUANTITIES OF HAZARDOUS WASTE MANAGED WITHIN THE PUREX STORAGE TUNNELS}

Because the dangerous waste is an integral part of radioactively contaminated material, the dangerous waste is managed as mixed waste. Table 1 contains an inventory of waste stored within the PUREX Storage Tunnels, as of February 1995. 


\subsection{WASTE AMALYSIS PARAMETERS}

Analytical requirements were selected on the basis of knowledge required for the safe handling and storage of the waste within the PUREX Storage

Tunnels for operational compliance, including any operational issues.

\subsection{WASTE IDENTIFICATION}

A prerequisite step in proper waste management is to adequately address whether waste being considered for management within the PUREX Storage Tunnels falls within the scope of this facility's permit. This includes identifying any hazardous waste in accordance with regulatory and permit requirements and applicability of any land disposal restricted waste.

This chapter provides information on how the chemical and physical characteristics of the mixed waste currently stored in the PUREX Storage Tunnels were determined so the dangerous waste is stored and managed properiy.

Material presentiy stored in the PUREX Storage Tunnels contains the following dangerous waste:

- Lead

- Mercury

- Silver and Silver Salts

- Chromium

- Cadmium.

Dangerous waste generally is either attached to or contained within some materials in the storage tunnels. Because the dangerous waste is an integral part of radioactively contaminated material, this material is managed as a mixed waste. Table 1 provides an approximation of the total amount of dangerous waste contained in the PUREX Storage Tunnels as of February 1995.

Storage of non-PUREX waste is reviewed on a case-by-case basis. Sampling, chemical analysis, and/or process knowledge (as discussed in the following section) are required to confirm the characteristics and quantities of dangerous waste to be stored. Future waste and dangerous constituents might not be in the same configuration or form as described in the following sections.

\subsubsection{Lead}

Lead stored was used in various capacities during past Hanford Facility operations. Primary functions of lead included use as weights, counterweights, and radiation shielding. Often the lead is encased in steel (carbon or stainless) to facilitate its attachment to various types of equipment. 


$$
\text { WHC-SD-EN-WAP-007, Rev. } 1
$$

Lead exhibits the characteristic of toxicity as determined by the toxicity characteristics leaching procedure and is designated D008 :-

[HAC 173-303-090(8)]. The quantity of lead present could produce an extract greater than $500 \mathrm{mi} 1 \mathrm{ligrams}$ per liter should the lead be exposed to a leachate. However, because the bulk of the lead is encased in steel, is stored inside a weather-tight structure, and is elevated above floor level on railcars that isolate the lead from other materials stored, the potential for exposure of bare lead to a leachate is considered to be negligible.

Sampling and chemical analysis is not performed on lead associated with the material placed in the PUREX Storage Tunnels. The quantity of lead is determined from a review of the fabrication drawings for material removed from the PUREX Plant, or from manifests and/or sample analyses provided from onsite sources before receipt of waste. Therefore, the accuracy of the estimate of the amount of lead presently stored in each tunnel is limited to the data. available from existing fabrication drawings. The estimated quantity of lead (Table 1) accounts only for the lead that has been removed from the PUREX Plant. Counterweights on equipment dunnage and lead used for shielding cannot be quantified by existing historical records and are not included in the amount of lead listed. However, following removal, the material will be examined and any suspect attachments will be removed, evaluated, and disposed of in accordance with established procedures.

\subsubsection{Mercury}

Mercury is contained within thermowells that are an integral part of irradiated reactor fuel dissolvers used at the PUREX PIant. The dissolvers are large $304 \mathrm{~L}$ stainless steel process vessels that are approximately. 2.7 meters in diameter, 7.3 meters tall, and weigh approximately 26,309 kilograms. The outer shell is constructed of a 1-centimeter-thick plate. The dissolvers were used in decladding and dissolving irradiated reactor fuel in the PUREX Plant.

Depending on the specific dissolver in question, 19.1 or 45.4 kilograms of mercury (1.4 or 1.771 iters) were poured into each of the two thermowe $11 \mathrm{~s}$ per dissolver (38.1 or 45.4 kilograms total per dissolver) following vertical installation of the dissolvers inside the PUREX canyon and before it was insta]led in a process cell. The mercury served to transfer heat from the dissolver interior to the thermohm temperature sensor mounted within the thermowell. This mercury remains with in the thermowells of discarded dissoivers. In preparation for storage, the thermohms were removed and the upper end of each thermowell was plugged with a $304 \mathrm{~L}$ stainless steel nozzle plug. In storage, the discarded dissolver rests in an inclined position in a cradle on the railcar. The mercury contained in the thermowells remains in the lower portion of each thermowell and, under normal conditions, is never in contact with the mechanical closure on the nozzle end of the thermowell.

Mercury exhibits the characteristic of toxicity as determined by the toxicity characteristics leaching procedure and is designated D009 [WAC 173-303-090(8)].

52 
WHC-SD-EN-WAP-007, Rev. 1

The potential for mercury to become exposed to Teachate is considered negligible. The PUREX Storage Tunnels are designed and constructed as weather-tight structures. Further, the mercury is encased in a stainless steel pipe within a stainless steel vessel that is stored on a railcar above the floor level of the tunnels. Therefore, exposure of the mercury stored in the tunnels to leachate is not considered a credible occurrence.

Sampling and chemical analysis is not performed on mercury associated with the dissolvers stored in Tunnel Number 2 . The quantity of mercury present in each thermowell is documented on Table 1.

\section{1 .3 Silver}

Silver, mostly in the form of silver salts deposited on unglazed ceramic packing, is contained within the discarded silver reactors stored in Tunnel Number 2. The silver reactors were used to remove radioactive iodine from the offgas streams of the irradiated reactor fuel dissolvers. The reactor vessel is approximately 1.4 meters in diameter by 4.1 meters tall and is constructed of 1-centimeter $304 \mathrm{~L}$ stainless steel. The vessel contains two 1.2-meter-deep beds of packing. Each bed consists of a 30.5-centimeter depth of 2.5-centimeter unglazed ceramic saddles topped with a 0.6 -meter depth of 1.3-centimeter unglazed ceramic saddles. The two beds are separated vertically by a distance of about 0.6 meter, and each bed rests on a support made of stainless steel angles and coarse screen. The packing was coated initially with 113.4 kilograms of silver nitrate used for iodine retention. Nozzles on the top of the reactor were provided to allow flushing and/or regeneration of the packing with silver nitrate solution as the need arose.

Because of competing reactions, which include conversion of silver nitrate to silver jodide, reduction of silver nitrate to metallic silver, and formation of silver chloride, the packing of a stored silver reactor contains a mixture of silver nitrate, silver halides, and silver fines.

Silver salts exhibit the characteristics of toxicity as determined by the toxicity characteristics leaching procedure and are designated 0011 [WAC 173-303-090(8)]. In addition, nitrates exhibit the characteristic of ignitability and also are designated as D001 [WAC 173-303-090(5)].

The potential of silver, including silver salts, stored in the PUREX Storage Tunnels to become exposed to leachate is considered negligible. Silver is contained within a stainiess stee] vessel, stored inside a weather-tight structure, and elevated above floor level on a railcar. Therefore, exposure of the silver stored in the tunnels to leachate is not considered to be a credible occurrence. Also, the contained silver is isolated from contact with any combustibles; therefore, the possibility of ignition is considered to be extremely remote.

Provisions for taking samples of the packing were not provided in the design of the vessels. Therefore, sampling and chemical analys is is not performed for silver salts before placing a silver reactor in storage. However, for accountability purposes, the total silver content (Table 1 ) is 
I considered to be silver nitrate, the salt that exhibits the characteristics of

2 both ignitability and toxicity.

The quantity of silver salts contained within a discarded silver reactor is a function of silver nitrate regeneration history. Operating records (process knowledge) of regenerations and flushes are used to estimate the total accumulation of silver within each reactor.

\subsubsection{Chromium}

Presently, chromium stored in Tunnel Number 2 is contained within a failed concentrator. The concentrator is a vertical tube structure that was used to concentrate aqueous streams from the final uranium cycle, finat plutonium cycles, final neptunium cycles, and condensate from the acid recovery system for recycle. Following service, the concentrator was inspected and found to contain silicate solids with high levels of chromium from the corrosion of stainless steel.

Chromium exhibits the characteristic of toxicity as determined by the toxicity characteristics leaching procedure and is designated 0007 [WAC $173-303-090(8)]$.

The potential for the chromium stored in Tunnel Number 2 to become exposed to leachate is considered negligible. Tunnel Number 2 is designed and constructed to be weather-tight. Further, the chromium is encased within a $304 \mathrm{~L}$ stainless steel vessel that is stored on a railcar above the floor level of the tunnel. Therefore, exposure of the chromium stored in the tunnel to leachate is not considered to be a credible occurrence.

The quantity of chromium within the concentrator was estimated by calculating the volume of silicate solids and the percentage of chromium within the silicate solids.

\subsubsection{Cadmium}

Present1y, cadmium stored in the PUREX Storage Tunnel Number 2 is associated with radiation shielding and with a dissolver moderator. The cadmium was used to shield equipment from radiation and consists of sheets of the metal attached to lead, both of which could be encased in steel.

The dissolvers are annular vessels that are geometrically favorable for criticality safety. The dissolvers were placed over cadmium lined (neutron absorbers) moderators for additional criticality safety. The moderator is a centrally located, cylindrical, cadmium-jacketed 0.08-centimeter-thick concrete 15.2-centimeter-thick neutron absorber. The moderators are approximately 4.4 meters tall by approximately 1.5 meters outer diameter.

Cadmium exhibits the characteristic of toxicity as determined by the toxicity characteristics leaching procedure and is designated 0006 [WAC 173-303-090(8)]. If exposed to a leachate, the quantity of cadmium present could produce an extract having a concentration of greater than or 
equal to 1 milligram per liter, but less than 100 milligrams per 1iter; therefore, the mixed waste is managed as a WTO2 [WAC 173-303-100(5)], dangerous waste, and is designated further as WCO2 [WAC 173-303-100(7)].

The potential for the cadmium stored in Tunnel Number 2 to become exposed to leachate is considered negligible. Tunnel Number 2 is designed and constructed to be weather-tight. Further, the cadmium is stored on a railcar above the floor level of the tunnel.

The quantity of cadmium is determined from a review of the fabrication drawings for material removed from the PUREX Plant. The estimated quantity of cadmium (Table 1) accounts only for the cadmium removed from PUREX Plant.

\subsubsection{Identification of Incompatible Waste}

The next step was to ensure that sufficient information has been provided concerning the waste so the waste can be managed properly. This included identifying incompatible waste. These safety issues primarily are related to prevention of unwanted chemical reactions that could create a catastrophic situation, such as a fire, an explosion, or a large chemical release.

\subsubsection{Operational Considerations}

Sufficient information must be available to ensure that incoming waste meets operational acceptance limits, e.g., physical size, radiation limits and permit conditions. These operating specifications are limits and controls imposed on a process or operation that, if violated, could jeopardize the safety of personnel, and could damage equipment, facilities, or the environment. Operating specifications have been established from operating experience, process knowledge and calculations.

\subsection{PARAMETER AND RATIONALE SELECTION PROCESS}

This WAP describes the process to ensure that the dangerous waste components of the material stored in the tunnels are properly characterized and designated so that dangerous and mixed waste is managed properly.

The parameters considered for waste designation under WAC 173-303-070(3) and the rationale for their application are discussed in the following sections.

\subsubsection{Discarded Chemical Products}

The first category of dangerous waste designation is "Discarded Chemical Products" (WAC 173-303-081). The waste stored in the tunnels does not fit the definitions in WAC 173-303-081 for a discarded chemical product. Therefore, the dangerous waste stored in the PUREX Storage Tunnels is not designated as a discarded chemical product. 
WHC-SD-EN-WAP-007, ReV. 1

\subsubsection{Dangerous Waste Sources}

The second category of dangerous waste designation is "Dangerous Waste Sources" (WAC 173-303-082). The waste stored in the tunnels is not listed on the "Dangerous Waste Sources List" (WAC 173-303-9904). Therefore, the dangerous waste stored in the PUREX Storage Tunnels is not designated as a dangerous waste source.

\subsubsection{Dangerous Waste Characteristics}

The third category of dangerous waste designation is "Dangerous Waste Characteristics" (WAC 173-303-090). The characteristics are as follows.

- Characteristic of Ignitability--Although the solid silver nitrate has not been tested in accordance with Appendix $F$ of 49 CFR 173, the waste is assumed to be an oxidizer as specified in 49 CFR 173.127(a). Therefore, the silver nitrate waste is assumed to exhibit the characteristic of ignitability under WAC 173-303-090(5) and is designated as D001.

- Characteristic of Corrosivity--Some of the material stored within the tunnels either has contained or has been in contact with corrosive liquids. The standard operating procedure has been to flush vessels with water to recover as much special nuclear material as practical. Also, flushing removes much of the radioactive contamination, minimizing the spread of contamination during handling. Currently, the final aqueous rinse is sampled and analyzed to confirm that the pH is greater than 2 and less than 12.5. Therefore, the waste stored in the PUREX Storage Tunnels is not designated as corrosive waste.

- Characteristic of Reactivity--The waste stored in the tunnels does not meet any of the definitions of reactivity as defined in HAC 173-303-090(7). The waste material is not unstable, does not react violently with water, does not form explosive mixtures, or does. not generate toxic gases. Therefore, the waste stored in the PUREX Storage Tunnels is not designated as reactive waste.

- Characteristic of Toxicity--Lead, mercury, silver, chromium, and cadmium are identified on the Toxicity Characteristics list. The quantity of these materials stored in the tunnels is sufficient that, should the substances come in contact with a leachate (an event considered unlike]y), the concentration of the extract could be above the limits identified in the list. Therefore, this waste is designated D006, D007, D008, D009, and D011.

The PUREX Storage Tunnels also are permitted for barium (D005), and selenium (DO10). Currently, there is no waste stored in the tunnels that is designated for D005 or D010; however, there is a potential for waste with these waste numbers to be stored within the tunnels. 


\subsubsection{Dangerous Waste Criteria}

The fourth category of dangerous waste designation is "Dangerous Waste Criteria" (HAC 173-303-100). The criteria are as follows:

- Toxicity Criteria--Cadmium meets the toxicity criteria in WAC 173-303-100(5) when performing a book designation. Because of the concentrations present, the waste containing these constituents is designated as dangerous waste (DW) and is assigned the dangerous waste number of WT02.

- Persistence Criteria--Currently, no waste stored in the tunnels has been designated as persistent per WAC 173-303-100(6).

- Carcinogenic Criteria--Cadmium meets the carcinogenic criteria in WAC 173-303-100(7) when performing a book designation. Because of the concentration, waste containing cadmium is designated as a dangerous waste and is assigned the dangerous waste number HCO2.

\subsubsection{Waste Designation Sumary}

The mixed waste currently stored in the PUREX Storage Tunnels is. designated as follows:

- Lead--D008; EHW

- Mercury--DO09; EHW

- Silver and Silver Salts--D001, D011; EHW

- Chromium--D007; EHW

- Cadmium--D006, WT02, WC02; DW.

\subsection{RATIONALE FOR PARAMETER SELECTION}

Refer to Section 2.2.

\subsection{SPECIAL PARAMETER SELECTION}

Refer to Section 2.2 .

\subsection{SELECTION OF SAMPLING PROCEDURES}

The following sections discuss the sampling methods and procedures that will be used. Sampling usually will be in accordance with requirements contained in the pertinent sampling analysis plan, data quality objectives, procedures, and/or other documents that specify sampling and analysis parameters. 
1

43

\subsection{SAMPLING STRATEGIES}

The only analysis presently used in support of the PUREX Storage Tunnels operation is a corrosivity check on the final in-place aqueous rinse of discarded vessels before the vessels are released for storage. The $\mathrm{pH}$ is determined by a pH meter using U.S. Environmental Protection Agency (EPA) Test Method 9040 or 9041 in Test Methods for the Evaluation of Solid Waste: Physical/Chemical Methods (EPA 1986). RCRA sampling will not be performed on any waste currently stored in the PUREX Storage Tunnels.

There is a potential for the PUREX Storage Tunnels to receive waste that is not generated at the PUREX Facility. Any required sampling strategies associated with this waste will be developed on a case-by-case basis.

\subsubsection{Sampling Methods}

Process knowledge of the characteristics and the quantities of the dangerous waste to be stored in the PUREX Storage Tunnels is considered sufficient to properly designate and manage the stored waste.

The waste currently stored in the tunnels is lead, mercury, chromium, cadmium, and silver. Sampling and chemical analysis of the lead, mercury, cadmium, or chromium to confirm their presence would not provide additional data beneficial to proper management of the waste and would not be in compliance with as low as reasonably achievable (ALARA) principles. The silver salts are nonuniformly distributed on ceramic packing contained within a large stainless steel reactor vessel. Representative sampling of the packing in $p l a c e$ is not considered to be practical and therefore is not performed.

If RCRA sampling is required for operation of the PUREX Storage Tunnels, representative sampling methods 1 isted in WAC 173-303-110 or some other method approved by the Washington State Department of Ecology (Ecology) will be used.

In the event the PUREX Storage Tunnels receive waste from other Hanford Facility activities, sampling, chemical analysis, and/or process knowledge will be required to confirm the characteristics and quantities of mixed waste to be stored. Storage of non-PUREX Facility waste will be reviewed on a caseby-case basis.

\subsubsection{Frequency of Analyses}

Because the dangerous waste components of mixed waste stored in the PUREX Storage Tunnels are stable and will remain undisturbed for a long time, the waste designations and quantities present will remain the same as assigned at the time of storage. Therefore, repeated analys is is not considered necessary to ensure that waste designation data are representative. 
In the event the PUREX Storage Tunnels receive waste from other Hanford Facility activities, this waste also will remain undisturbed and the designations and quantities will be consistent with those at the time of storage, making repeated analysis unnecessary.

\subsection{SELECTION OF SAMPLING EQUIPMENT}

The only analysis presently used in support of the PUREX Storage Tunnels operation is for corrosivity on the final in-place aqueous rinse of discarded vessels before the vessels are released for storage. The $\mathrm{pH}$ is determined by Method 9040 or 9041 (SW-846). RCRA sampling will not be performed on any waste currently stored in the PUREX Storage TunneTs.

\subsection{MAINTAINING AND DECONTAMINATING FIELD EQUIPMENT}

A11 RCRA sampling equipment used to collect and transport samples must be free of contamination that could alter test results. Equipment used to obtain and contain samples must be clean. Acceptable cleaning procedures for sample bottles and equipment include, but are not 1 imited to, washing with soap or solvent, and steam cleaning. After cleaning, cleaning residues must be removed from all equipment that could come into contact with the waste. One method to remove these residues would be a solvent (acetone or other suitable solvent) rinse followed by a final rinse with deionized water. Equipment must be cleaned before use for another sampling event.

After completion of sampling, equipment should be cleaned as indicated previously. If decontamination of the equipment is not feasible, the sampling equipment should be disposed of properly.

\subsection{SAMPLE PRESERVATION AND STORAGE}

Following RCRA sampling, sample preservation follows those procedures set forth for the specific analysis identified. Preservation will be in accordance with the methods stated in SW-846 or any of the test methods adopted by the Hanford Facility that meet WAC 173-303 requirements. No preservation method will be used when there are ALARA concerns.

\subsection{QUALITY ASSURANCE/QUALITY CONTROL PROCEDURES}

The only test method presently used in support of the PUREX Storage Tunnels operation is a corrosivity check on the final in-place aqueous rinse of discarded vessels before the vessels are released for storage. RCRA sampling will not be performed on any waste currently stored in the PUREX Storage Tunnels. Field duplicates, field blanks, trip blanks, and equipment blanks will not be taken. Split samples could be taken at the request of the EPA or Ecology.

Generally, quality assurance and quality control ( $Q A / Q C)$ requirements for sampling will be divided between paperwork requirements, such as chain-of- 
1 custody, and sampling and analysis activities. This section addresses

sampling $Q A / Q C$ requirements. Analytical $Q A / Q C$ is discussed in Section 4.0.

A chain-of-custody procedure is required for all sampling identified by this WAP. At a minimum, the chain of custody must include the following:

(1) description of waste coliected, (2) names and signatures of samplers, (3) date and time of collection and number of containers in the sample, and (4) names and signatures of persons involved in transferring the samples.

\subsection{HEALTH AND SAFETY PROTOCOLS}

The safety and health protocol requirements established for the Hanford site must be followed for all RCRA sampling activities required by this WAP.

\subsection{LABORATORY SELECTION AND TESTING AND ANALYTICAL METHODS}

This section discusses laboratory selection and the types of acceptable analytical methods for RCRA samples.

\subsection{LABORATORY SELECTION}

Laboratory selection is limited as only a few Taboratories are equipped to handle mixed waste because of the special equipment and procedures that must be used to minimize personnel exposure. Laboratory selection will depend on laboratory capability, nature of the sample, timing requirements, and cost. At a minimum, the selected laboratory must have the following:

- A comprehensive $Q A / Q C$ program (both qualitative and quantitative)

- Technical analytical expertise

- An effective information management system.

These requirements will be met if the selected laboratory follows the pertinent requirements contained in the Hanford Analytical Services Quality Assurance Plan (DOE/RL-94-55). The selected laboratory also can meet these requirements by having some other type of $Q A / Q C$ program as long as equivalent data quality is achieved.

\subsection{TESTING AND ANALYTICAL METHODS}

The testing and analytical methods for corrosivity used by the various onsite analytical laboratories are outlined in SW-846. These methods wilT in some cases deviate from SW-846 and American Society for Testing and Materialsaccepted specifications for holding times, sample preservation, and other specific analytical procedures. These deviations are discussed in Analytical Methods for Mixed Waste Analyses at the Hanford Site (DOE/RL-94-97). 
WHC-SD-EN-WAP-007, Rev. 1

\subsection{WASTE. RE-EVALUATION FREQUENCIES}

Re-evaluation of waste within the PUREX Tunnels will not occur because of high radiation levels and the way the railcars are positioned in the tunnels. The waste is expected to remain stable.

\section{6:0 SPECIAL PROCEDURAL REQUIREMENTS}

The following sections describe special procedural requirements associated with waste in the PUREX Storage Tunnels.

\subsection{PROCEDURES FOR RECEIVING WASTES GENERATED OFFSITE} Site.

The PUREX Storage Tunnels do not accept waste generated off the Hanford

\subsection{PROCEDURES FOR IGNITABLE, REACTIVE, AND INCOMPATIBLE WASTE}

Presently, the only ignitable, reactive, or incompatible dangerous waste. stored in the PUREX Storage Tunnels is the silver. nitrate coating on the ceramic packing inside the silver reactors. This material is confined to the interior of a large stainless steel vessel (Section 2.1.3) that separates this material from all other waste material stored in the tunne1. The requirements in WAC 173-303-395(1)(a) require 'No Smoking' signs be conspicuously placed wherever there is a hazard present from ignitable or dangerous waste. 'No Smoking' signs are not considered appropriate at the PUREX Storage Tunne]s because the tunnels are a designated radiation area. Smoking is not allowed in any radiation area on the Hanford Site and rules prohibiting smoking are strictiy enforced. Because the posting of radiation area barriers serves to achieve the no smoking intent of WAC 173-303-395(1)(a), posting and maintaining 'No Smoking' signs are not considered appropriate.

Isolated areas within the PUREX Storage Tunnels have radiation levels in excess of 5 roentgen per hour. Personnel entry into such radiation areas to make periodic inspections [e.g., an annual fire inspection as required by WAC 173-303-395(1)(d) for storage areas containing ignitable waste] would be inconsistent with ALARA guidelines of the Atomic Energy Act of 1954. Therefore, such inspections are not performed. The rationale for operations associated with the PUREX Storage Tunnels are addressed further in a petition for rulemaking submitted to Ecology (Freeberg 1989), in fulfillment of a Tri-Party Agreement milestone (Milestone M-22-01). (Ecology et a1. 1994).

\subsection{PROVISIONS FOR COMPLYING WITH LAND DISPOSAL RESTRICTION REQUIREMENTS}


Operation of the PUREX Storage Tunnels does not involve land disposal or treatment of dangerous waste. The information provided by the generating unit regarding land disposal restrictions of dangerous waste is sufficient to operate the PUREX Storage Tunnels in compliance with land disposal restriction requirements. When final disposition of the waste occurs, this information will be passed on for final treatment or disposal of the waste.

\subsection{DEVIATIONS FRON THE REQUIREMENTS OF THIS PLAN}

Management may approve deviations from this plan if special circumstances arise that make this prudent. These deviations must be documented in writing with a copy to be to retained by the management.

\subsection{RECORDKEEPING}

Records associated with this waste analys is $\mathrm{plan}$ and waste verification program are maintained by PUREX Regulatory Compliance personnel. These records will be maintained until closure of the PUREX Storage Tunnels.

Records associated with the waste inventory will be maintained for 5 years. 
WHC-SD-EN-WAP-007, Rev. 1

\subsection{REFERENCES}

DOE/RL-94-55, Hanford Analytical Services Quality Assurance Plan, Rev. 2, U.S. Department of Energy, Richland Operations Office, Richland, Washington.

DOE/RL-94-97, Analytical Hethods for Mixed Waste Analyses at the Hanford Site, Rev. O, U.S. Department of Energy, Richland Operations Office, Richland, Washington.

Ecology, EPA, and DOE, 1994, Hanford Federal Facility Agreement and Consent Order, Vols. 1 and 2, Washington State Department of Ecology, U.S. Environmental Protection Agency, U.S. Department of Energy, Olympia, Washington.

EPA, 1986, Test Methods for the Evaluation of Solid Waste: Physical/Chemical Methods, SW-846, 3rd ed., U.S. Environmental Protection Agency, Washington, D.C.

Freeberg, R. D., 1989, Proposed Petitions for Rulemaking Changes for Interim Mi Jestone M-22-01, Correspondence dated September 27, 1989, Number 8955715 , U.S. Department of Energy-Richland Operations office, Richland, Washington. 
WHC-SD-EN-WAP-007, Rev. 1

This page intentionally left blank. 
WHC-SD-EN-WAP-007, Rev. 1

Table 1. PUREX Storage Tunnels Inventory. (sheet 1 of 3 )

\section{PUREX \#1 STORAGE TUNNEL (218-E-14)}

\section{TUNNEL IS AT ITS CAPACITY AS OF 1/22/65}

PUREX \#1 Storage Tunnel is located at the southeast end . of the PUREX Plant and is an extention of the railroad tunnel. The storage area is approximately 109 meters long, 6.9 meters high and 5.8 meters wide. The tracks have a one percent downgrade toward the south end of the tunnel. The capacity of the Storage Tunnel is eight modified railroad cars, 12.8 meters long.

position $1 . \& 2$.

HA COLUMN AND MISC JUMPERS IN BOX

PLACED IN TUNNEL \#1 ON 6/60

HA 4,700 CU. FT., 400 CURIES, 5 rem $/ \mathrm{hr}$. @ 60', JUMPRS 2,190 CU. FT., 2,000 CURIES, Pb $-115 \mathrm{Kg}$.

BOX $\mathrm{H}_{2-58373}$ CO

E-F11 \#1 (1WW WASTE) CONCENTRATOR FAILED 7/24/60,

3. E-F11 \#1 (1WW WASTE) CONCENTRATOR FAILED 7/24/60
PLACED IN TUNNEL \#1 ON $7 / 29 / 60,12.5 \mathrm{rem} / \mathrm{hr}$. @ 100", 1,900 CU. FT., 40, 000 CURIES AFTER FIFTY-FIVE MONTHS SERVICE.

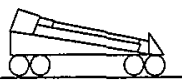

4. G-E2 CENTRIFUGE. MISC JUMPERS IN BOX AND TWO TUBE BUNDLES. PLACED IN TUNNEL \#1 ON 12/24/60 (FUG SER\# 762) 2,465 CU. FT., 3,000 CURIES, Pb $--115 \mathrm{Kg} .1 .5 \mathrm{rem} / \mathrm{hr}$. @ $150^{\prime}$.

G

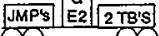

5. E-H4 (3WB) CONCENTRATOR FAILED $1 / 4 / 61$.
PLACED IN TUNNEL \#1 ON $1 / 4 / 61,150 \mathrm{mrem} / \mathrm{hr}$. @ 50',
2,336 CU, FT., 1,000 CURIES. AFTER FIVE YEARS SERVICE.

5. E-H4 (3WB) CONCENTRATOR FAILED $1 / 4 / 61$.
PLACED IN TUNNEL \#1 ON $1 / 4 / 61,150 \mathrm{mrem} / \mathrm{hr}$. @ 50',
2,336 CU, FT., 1,000 CURIES. AFTER FIVE YEARS SERVICE.

5. E-H4 (3WB) CONCENTRATOR FAILED $1 / 4 / 61$.
PLACED IN TUNNEL \# 1 ON $1 / 4 / 61,150 \mathrm{mr} / \mathrm{m} / \mathrm{hr}$. @ 50',
2,336 CU. FT., 1,000 CURIES. AFTER FIVE YEARS SERVICE.

6. E-F6 (2WW WASTE) ORIGINAL CONCENTRATOR FAILED 4/21/61. PLACED IN TUNNEL \#1 ON 4/21/61, $5 \mathrm{r}$ m/ hr. @ 20", 2,336 CU. FT., 700 CURIES. AFTER FIVE YEARS FOUR MONTHS SERVICE.

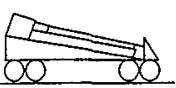

7. E-F11 (IWW WASTE) \#2 CONCENTRATOR FAILED $2 / 1 / 62$. PLACED IN TUNNEL \#1 ON 2/8/62, $25 \mathrm{rem} / \mathrm{hr}$. @ 150', 2,336 CU. FT. 40,000 CURIES. AFTER EJGHTEEN MONTHS SERVICE.

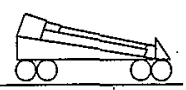

8. E-F6 (2WW WASTE) \#3 SPARE CONCENTRATOR FAILED 5/23/64. PLACED IN TUNNEL \#1 ON 1/22/65 FLAT CAR 3621. 2,400 CU.FT., 700 CURIES, 5 rem/hr. @ 20'.
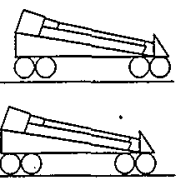
WHC-SD-EN-WAP-007, Rev. 1

Table 1: PUREX Storage Tunnels Inventory. (sheet 2 of 3)

\section{PUREX \#2 STORAGE TUNNEL (218-E-15)}

PUREX \#2 Storage Tunnel is located at the southeast end of the PUREX Plant and is an extention of the railroad tunnel. The storage area is approximately 514.5 meters long, 7.9 meters high and 10.4 meters wide. The tracks have $a$ one percent downgrade toward the south end of the tunnel. The capacity of the Storage Tunnel is $38-40$ modified railroad cars, 12.8 meters long.

position The Tunnel contains 21 cars as of $2 / 95$.

1. E-F6 \# (2WW WASTE) CONCENTRATOR, TK F 15-2, ONE TUBE BUNDLE AND AGITATOR MOTORS PLACED IN TUNNEL ON 12/12/67 ON CAR 61439 $2,400 \mathrm{CU}$. FT., 700 CURIES, $1.3 \mathrm{rem} / \mathrm{hr}$. @ 100:

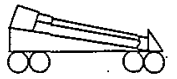

2. E-F6 \#5 (E-H4 3WB) CONCENTRATOR, TWO TUBE BUNDLES PLACED IN TUNNEL ON 3/26/69 ON CAR MILW 60883 2,400 CU. FT., 500 CURIES, $800 \mathrm{mrem} / \mathrm{hr}$. @ 24.

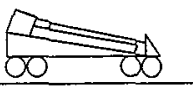

3. E-F6 \#6 (2WW WASTE) CONCENTRATOR, TWO TUBE BUNDLES FAILED PLACED IN TUNNEL ON $3 / 19 / 70$ ON CAR 3612. 2, 400 CU. FT., 700 CURIES, $500 \mathrm{ram} / \mathrm{hr}$. @ 2'.

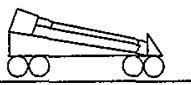

4. L CELL PACKAGE IN A SEALED STEEL BOX (H2-66012) PLACED IN TUNNEL ON 12/30/70 ON CAR MILW 60033 2,400 CU.FT., 500 GRMS PU, $200 \mathrm{mrem} / \mathrm{hr}$. @ CONTACT.

5. F2 SILVER REACTOR, FG DEMISTER, VESSEL VENT LINE STEEL CATWALK AND GUARD RAILS. PLACED IN TUNNEL ON 2/26/71 ON GONDOLA CAR $4610.2,400 \mathrm{CU}$. FT., 20 CURIES, Ag $-2625 \mathrm{Kg}, 2 \mathrm{rem} / \mathrm{hr}$. @ CONTACT.

6. MODIFIED A3-1 TOWER, SCRUBBER, LID AND VAPOR LINE PLACED IN TUNNEL ON 12/12/71 ON GONDOLA CAR 4611. 2,400CU. FT., 10 CURIES, 1 rem/hr. @ CONTACT.

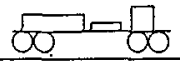

7. AS DISSOLVER

PLACED IN TUNNEL ON 12/22/71 ON NINE FT. SHORTENED CAR 858 2,400 CU.FT., 50 CURIES, $\mathrm{Hg} * \sim 45 \mathrm{Kg}, 5 \mathrm{rem} / \mathrm{hr}$. @ 5 '.

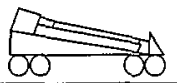

8. AIW1 FUEL ENDS IN STEEL LINER BOX AND NPR FUEL HANDLING EQUIPT. USED WITH THE SUSPECTED CANISTERS, ON CAR 19808 PLACED IN TUNNEL ON 8/29/72. 800 CU.FT., 17,500 CURIES, $10 \mathrm{rem} / \mathrm{hr}$. @ 150".

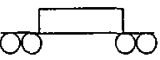

9. C3 DISSOLVER
PLACED IN TUNNEL ON 9/30/72 ON CAR 19811 $1590 \mathrm{CU}$. FT., 50 CURIES, $\mathrm{Hg}=\sim 45 \mathrm{Kg} ., 5 \mathrm{rem} / \mathrm{ht}$. @ $5^{\prime}$.

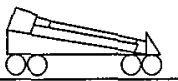

10. E-H4 (3WB) CONCENTRATOR, \#6I TUBE BUNDLE, PROTOTYPE COOLING COIL AND A F-F1 FILTER TANK. PLACED IN TUNNEL 8/30/83 ON CAR CDX-1, 2,400 CU.FT., 500 CURIES, $\mathrm{Hg}-\sim 40 \mathrm{Kg} ., \mathrm{Cd}-\sim 43 \mathrm{Kg} ., 800 \mathrm{mrem} / \mathrm{hr}$. @ 2'.

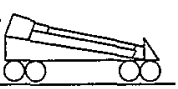

11. A3 DISSOLVER NESSEL \#10 AND HEATER VESSEL \#6) PLACED IN TUNNEL ON $1 / 18 / 86$ ON CAR 3613 $3,960 \mathrm{CU}$. FT., 0.81 CURIES, $\mathrm{Hg}-\sim 40 \mathrm{Kg} ., \mathrm{Cd}-\sim 43 \mathrm{Kg} .3 \mathrm{mrem} / \mathrm{hr}$. @ 3'.

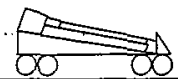

12. WHITE BOX (H2-58456) CONTAINING EIGHT TUBE BUNDLES \#S 57 , $60,62,64,67,68,74$, AND 76 PULSER $\# 5$ AND OLD HEATER DISS LID OLD STYLE DUMPING TRUNNIONS (9), PLACED IN TUNNEL ON 1/20/86 ON CAR 36115,438 CU.FT., 540 CURIES, 2 rem/hr. @ 3!.

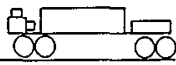


WHC-SD-EN-WAP-007, Rev. 1

Table 1. PUREX Storage Tunnels Inventory. (sheet 3 of 3)

PUREX \#2 STORAGE TUNNEL (218-E-15)

\section{position}

13. J5 TANK (NESSEL \#30). F1 COND NESSEL \#13) AND F12-B CELL 8LK. OLD FOUR-WAY DUMPER. DISS YOKE AND FLANGE PLATE, $3 \mathrm{rem} / \mathrm{hr}$. @ 1:. PLACED IN TUNNEL ON 1/21/86 ON CAR $19806.2,500$ CU. FT., 90 CURIES.

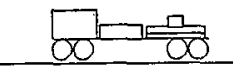

14. L-1 PULSER, 2-COLUMN CARTRIDGES, 1-JUMPER CUTTER, 3-JUMPER ALIONMENT TOOLS, 9-EXTERIOR DUMPING TRUNNIONS, 10-PUMPS, 3-AGITATORS, 4-TUBE BUNDLES, 2-VENT JUMPERS AND 7-YOKES. PLACED IN TUNNEL ON 11/18/87 ON CAR PX-10 (10A-19380) \& RACK
H2-96629.50.50 TONS, 3,600 CU. FT., 33,740 CURIES(REF:LETTER 12110-88-074), OC FLUOROTHENE $=180 \mathrm{Kg} . \mathrm{Pb}=2540 \mathrm{Kg} .5 \mathrm{rem} / \mathrm{hr}$.@ $15^{\prime}$

15. SILVER REACTOR, E-F2 STEAM HEATER AND STORAGE LINER (H2-65095) FULL OF CUT UP JUMPERS PLACED IN TUNNEL ON 5/13/88 ON CAR PX-9 (10A-19809) \& S/R CRADLE SK-GLR-11-2-87.20 TONS, 2,775 CU. FT., 240 CURIES (REF: LETTER 12110-88-074), Co - $13 \mathrm{Kg} ., \mathrm{Ag}-\sim 115 \mathrm{Kg}$., $\mathrm{Pb}=-230 \mathrm{Kg} .20 \mathrm{mrem} / \mathrm{hr} @ 20$.

16. E-J8-1 UNITIZED CONCENTRATOR VESS \#1 H2-52477, FAILED 3/11/89 PLACED ON STORAGE CAR H2-99608, PX-6 (10A-19028) AND INTO \#2 TUNNEL 4/6/89 GRAVEYARDS. EST. 42 TONS, 6,000 CU. FT. 1.5 CURIES (REF: LETTER 12113-89-027), $0.5 \mathrm{mrem} / \mathrm{hr}$. @ 10'.

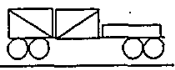
17. NORTH STORAGE LINER H2-65095 CONTAINING SIX PUMPS, ONE AGITATOR AND
CUT UP JUMPER (14 TONS). SOUTH STORAGE LINER H2-65095 CONTAINING ONE PUMP, ONE \#15 YOKE AND CUT UP JUMPERS (11.5 TONS). PLACED ON STORAGE CAR PX-19 (10A-19030) AND INTO \#2 TUNNEL 8/5/89 DAYS. EST 25.5 TONS, 2,574 CU. FT. 3.0 CURIES (REF: LETTER 12113-89-051), $80 \mathrm{mrem} / \mathrm{hr}$. @ 14.

18. T-F5 ACID ABSORBER, ID\#1-T-F5/F-168713, H2-52535 AND H2-52487/488. PLACED ON STORAGE CAR PX-2 AND INTO \#2 TUNNEL 4/8/94. EST 22 TONS, 835 CU. FT. 185 CURIES, $90 \mathrm{mrem} / \mathrm{hr}$. @ CONTACT.

19. FOUR METAL LINER STORAGE BOXES H-2-65095-3/H-2-100187-0 CONTAINING FAILED JUMPERS AND MISCELLANEOUS OBSOLETE CANYON EQUIPMENT ITEMS. PLACED ON STORAGE CAR PX-23 AND INTO \#2 TUNNEL 9/16/94. EST 60 TONS, 4032 CU. FT., 927 CURIES, $30 \mathrm{mrem} / \mathrm{hr}$. 2'.

20. E-H4-1 UNITIZED CONCENTRATOR (H-2-52477/56213)/(E-H4-1). PLACED IN TUNNEL ON 1/27/95 ON CAR PX-28. EST 40 TONS, 5,760 CU. FT., 3,070 CURIES, $C_{r}-8 \mathrm{Kg} ., 1000 \mathrm{mr} \theta \mathrm{m} / \mathrm{hr}$. @ 5'.

21. TANKE-5 (H-2-52453)/(F-166955), LEAD STOAAGE BOXASSEMBIY $(\mathrm{H}-2-131629) /(\mathrm{H}-2-131629-1), \mathrm{H} 4$ CONCENTRATOR TOWER $(\mathrm{H}-2-58102) /$ (F-223017-CBT-4), HOT SHOP COVER PLATE $(H-2-52222) /\left({ }^{\prime} Q^{*}\right)$, TUBE BUNDLE WASH CAPSULE (H-2-58647), DISSOLVER CHARGING INSERT (H-2-75875)/ (H-2-75875-1), LIFTING YOKE \#7A (H-2-96837), LIFTING YOKE \#9 (H-2-52458). PLACED IN TUNNEL ON 2/8/95. ON CAR PX-3609. EST 44 TONS, 3,457 CU. FT., 26,000 CURIES, Pb $-1930 \mathrm{Kg} ., 1000 \mathrm{mrem} / \mathrm{hr}$. @ 4!.
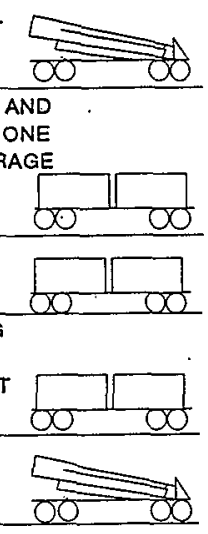
DOE/RL-90-25, Rev. 2

$11 / 95$

\section{APPENDIX 4A \\ ENGINEERING DRAWINGS}




\section{APPENDIX $4 A$}

\section{ENGINEERING DRAWINGS}

As-built drawings (aperture cards) for the PUREX Storage Tunnels:

H-2-55587 218-E-14 Structural Floor Plan and Section, Rev. 7

H-2-55588 Structural Sections and Details: Disposal Facility for Failed Equipment, Rev. 7

H-2-55589 Structural Sections and Details: Disposal Facility for Failed Equipment, Rev. ?

H-2-55594 Shielding Door Fill and Drain Lines Arrangement: Disposal Facility for Failed Equipment, Rev. 2

H-2-55597 Steam and Air Lines Relocation Layout: Disposal Facility for Failed Equipment, Rev. 1

H-2-55599 Electrical Door Control Plan, Elementary Diagram and Miscellaneous Details: Disposal Facility for Failed PUREX Equipment, Rev. 2

H-2-58175 PUREX Tunnel: As Built, May 1962, Rev. 2

$\mathrm{H}-2-58195$

Structural Sections and Details: Equipment Disposal - PUREX, Rev. 1 


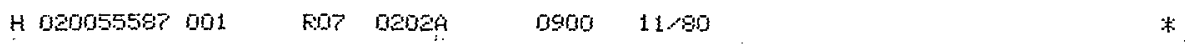

紊

H 020055586 001 001 0202A $050102,55 \quad$ *

*

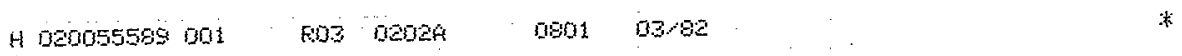

H $020055594001008 \quad 02024 \quad 000306 \% 50 \quad$ *

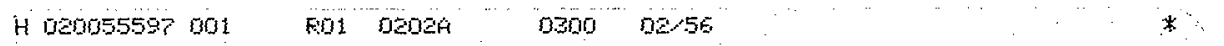

H 000055599001 F00 02029 7502 10,56

$\left[\begin{array}{c}0 \\ -1\end{array}\right.$

H020058175001 Frog $02024 \quad 0501$ 07/62

H 020058195001 F01 $52029 \quad 0901$ 04/65

我.

BOORUM \& PEASE

212-32

MADE IN U.S.A. PATENT NO. 3.643.360 
THIS PAGE INTENTIONALLY LEFT BLANKS 
DOE/RL-90-24, Rev. 2

$11 / 95$

\section{APPENDIX 7A}

UNIT-SPECIFIC CONTINGENCY PLAN FOR THE 218-E-14 AND 218-E-15 STORAGE TUNNELS 


\section{DOE/RL-90-24, Rev. 2}

$11 / 95$

APPENDIX 7A The building unit-specific contingency plan is updated annually. Future
5 updates will reflect terminology consistent with the permit application. 
UNIT-SPECIFIC CONTINGENCY PLAN FOR

THE 218-E-14 AND 218-E-15 STORAGE

TUNNELS
Document

Page

Issue Date
WHC-IP-0603-218-E-14/15

$i$ of $i i$

October 13,1995

Document Title: UNIT-SPECIFIC CONTINGENCY PLAN FOR THE 218-E-14 and

Prepared by:

Approved by:

Approved by:

Approved by:
218-E-15 STORAGE TUNNELS

$$
\frac{10-13-95}{\text { Date }}
$$

$$
\text { C.R. Haas }
$$

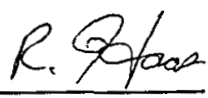

PUREX Regulatory Compi iance
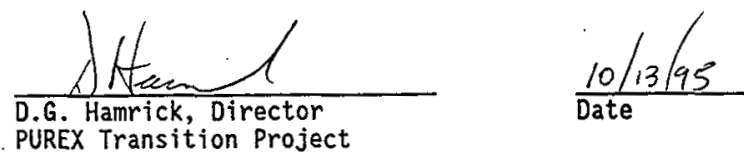

D.G. Hamrick, Director
PUREX Transition Project
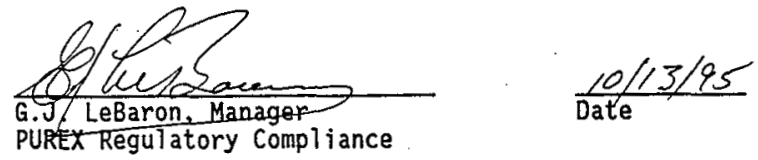

$$
\text { PUREX Regulatory Compliance }
$$

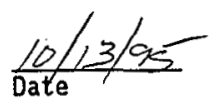




\section{CONTENTS}

1.0 GENERAL INFORMATION $(\mathrm{G}-1) \ldots \ldots \ldots \ldots \ldots \ldots$

1.1 FACILITY NAME . . . . . . . . ........ 1

1.2 FACILITY LOCATION ..................... 1

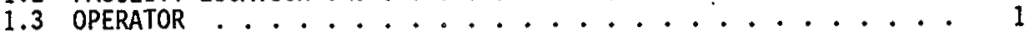

1.4 FACILITY CO-OPERATOR . . ............. 1

1.5 DESCRIPTION OF FACILITY OPERATIONS ............ 1

1.6 SITE PLAN ...................... 2

2.0 EMERGENCY COORDINATORS $(G-2) \ldots \ldots \ldots \ldots$

3.0 IMPLEMENTATION OF THE PLAN $($ G-3) $\ldots \ldots \ldots \ldots$

3.1 DANGEROUS AND/OR MIXED WASTE RELEASE .......... 3

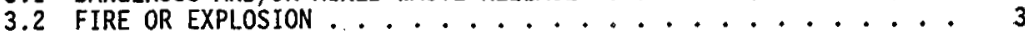

3.3 SEISMIC EVENT . . . . . . . . . . . . .... 4

3.4 AIRCRAFT CRASH .................. 4

3.5 BOMB THREAT/EXPLOSIVE DEVICE ........... 4

3.6 DAMAGED DANGEROUS AND/OR MIXED HASTE SHIPMENT $\ldots \ldots \ldots$

4.0 UNIT/BUILDING EMERGENCY RESPONSE PROCEDURES . . . . . . . 5

4.1 NOTIFICATION $(\mathrm{G}-4 \mathrm{a}) \ldots \ldots \ldots . \ldots 5$

4.2 IDENTIFICATION OF RELEASED/SPILLED MATERIALS ....... 5

4.3 HAZARD ASSESSMENT AND REPORT $\ldots \ldots$

4.4 PREVENTION OF RECURRENCE OR SPREAD OF FIRES, EXPLOSIONS, RELEASES ................. 5

4.5 POST-EMERGENCY ACTIONS $(G-4 f) \ldots \ldots 6$

5.0 EMERGENCY EQUIPMENT $(G-5) \ldots \ldots \ldots \ldots$

6.0 COORDINATION AGREEMENTS $(G-6) \ldots \ldots \ldots$

7.0 EVACUATION $(G-7) \ldots \ldots \ldots . \ldots \ldots$

8.0 REQUIRED REPORTS $(\mathrm{G}-8) \ldots \ldots \ldots \ldots \ldots$

9.0 REFERENCES . . . . . . . . . . . . . . 8 


\subsection{GENERAL INFORMATION (G-1)}

The PUREX (plutonium-uranium extraction) Storage Tunnels are located in the 200 East Area of the 1,450-square kilometer U.S. Department of Energy (DOE) operated Hanford Site in southeastern Washington State. This unit-specific contingency plan in conjunction with those portions of WHC-IP-0263-202A, Emergency P7 an for PUREX Facility, WHC-CM-4-43, Emergency Management Procedures and DOE/RL-93-75, Hanford Facility Contingency Plan that apply to the PUREX Storage Tunnels meet the requirements of this section.

1.1 FACILITY NAME: U.S. Department of Energy Hanford Site PUREX Storage Tunnels.

1.2 FACILITY LOCATION: Benton County, Washington; within the 200 East Area. Structures covered by this plan are:

$\begin{array}{ll}218-E-14 & \text { Tunnel Number } 1 \\ 218-E-15 & \text { Tunnel Number } 2\end{array}$

1.3 OPERATOR: U.S. Department of Energy Richl and Operations office 825 Jadwin Avenue Rich 1 and, Washington 99352

1.4 FACILITY CO-OPERATOR: Westinghouse Hanford Company P. O. Box 1970

Richland, Washington 99352

\subsection{DESCRIPTION OF FACILITY OPERATIONS}

The PUREX Storage Tunnels consist of two structures, 218-E-14 (Tunne1 Number 1) and 218-E-15 (Tunnel Number 2). The tunnels are used for the storage of material from the PUREX Plant and from other onsite sources. The material stored in the tunnels contains dangerous waste and varying amounts of radioactive contamination; therefore, the stored material is managed as mixed waste. Tunnel Number 1 is filled to capacity. Tunnel Number 2 currently has storage positions available and continues to receive mixed waste from the PUREX Plant and from other onsite activities until the tunnel is either filled to capacity or a determination is made that waste will no longer be received.

Mixed waste is stored in the PUREX Storage Tunnels on railcars that are modified to serve as both transporter and storage platforms. Each railcar is retrievab7e. However, because the railcars are stored on a single, dead-end railroad spur inside each storage tunnel, the railcars can be removed only in reverse order (i.e., last in, first out).

\subsection{SITE PLAN}

The PUREX Storage Tunnels Site PIan and evacuation route are shown in Figure 1 . 
UNIT-SPECIFIC CONTINGENCY PLAN FOR THE 218-E-14 AND 218-E-15 STORAGE TUNNELS
Document WHC-IP-0603-218-E-14/15

Page

Issue Date
2 of 8

August 28, 1995

Figure 1. PUREX Storage Tunnels Site Plan and Evacuation Route.

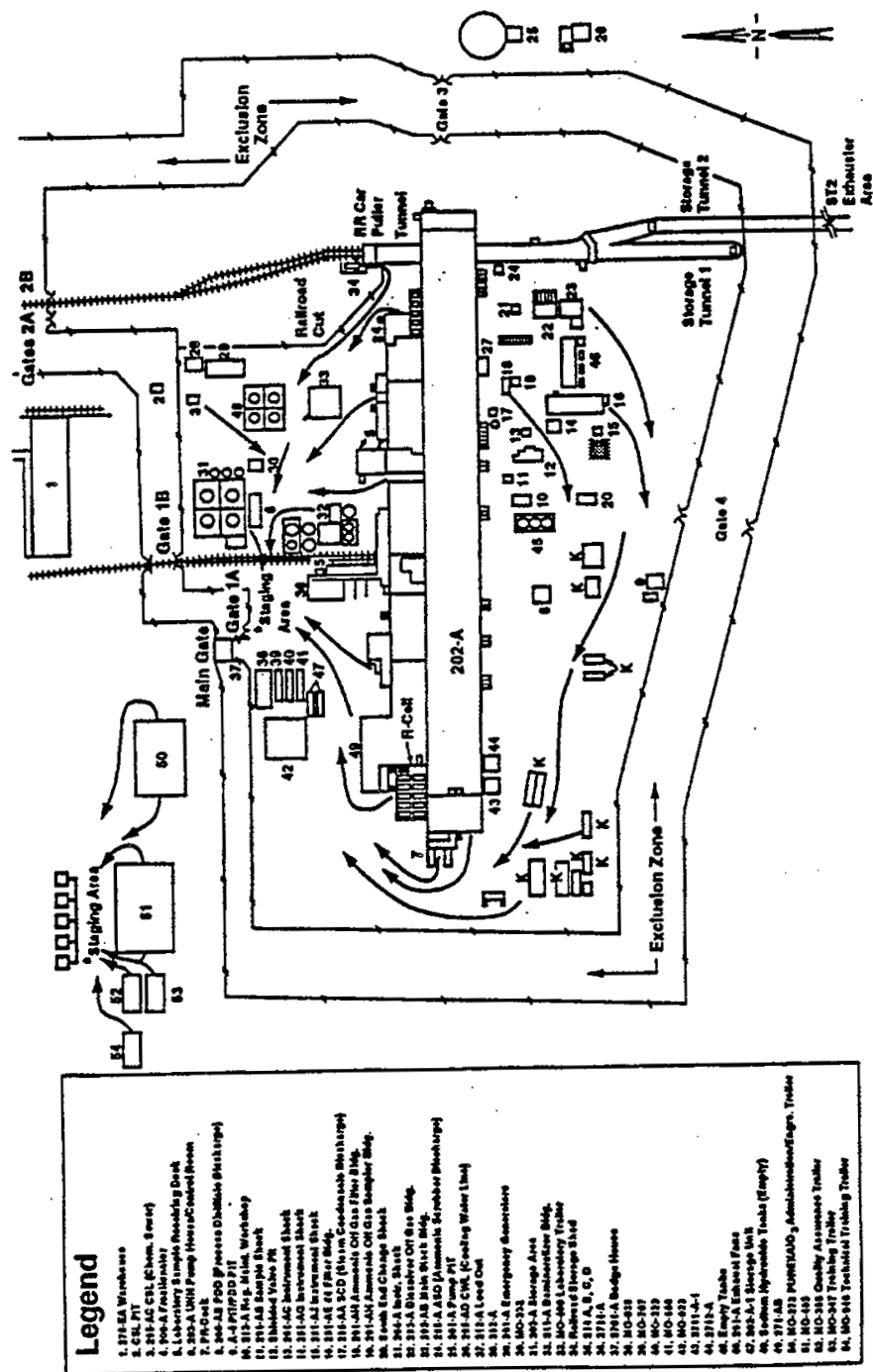




\subsection{EMERGENCY COORDINATORS (G-2)}

Emergency organization names, positions, work Tocations, and telephone numbers for the 218-E-14 and 218-E-15 Storage Tunnels are maintained in WHC-IP-0263-202A, Emergency P7an for PUREX Facility. Copjes are distributed, at a minimum, to appropriate facility locations and to emergency preparedness personnel.

Qual ifjcations for those designated with the duties of the emergency coordinator are outlined in WHC-IP-0263-202A, Emergency Plan for PUREX Facility.

\subsection{IMPLEMENTATION OF THE PLAN (G-3)}

Potential emergency conditions could include any of the following three basic categories:

(1) Operational (e.g., damaged waste shipment)

(2) Natural phenomena (e.g., earthquakes)

(3) Security contingencies (e.g., bomb threat).

Any of these conditions could lead to an emergency situation and require the implementation of this plan.

\subsection{DANGEROUS AND/OR MIXED WASTE RELEASE}

A seismic event, explosion, tornado, or an aircraft crash could cause damage to the storage tunnels and could involve environmental exposure to mixed waste.

Emergency responses for dangerous and/or mixed waste releases can be found in WHC-IP-0263-202A, Emergency Plan for PUREX Facility.

For classification of mixed waste release events, refer to the facility specific recognition and classification procedure in WHC-CM-4-43, Emeirgency Management Procedures. If the event does not meet emergency classification criteria, continue following facility-specific response and reporting procedures.

\subsection{FIRE OR EXPLOSION}

The fire hazard associated with the PUREX Storage Tunnels is considered to be very low because of the minimal amount of combustibles stored within the tunnels and the lack of an ignition source.

Because of the extremely remote potential of mixed waste to leach, water is not the preferred choice for fire control. Reduction of the air suppiy to the storage area by ișolation of the tunnel exhaust system should permit a fire to self-extinguish. Should the fire continue to spread, heavy equipment and cranes will be called to the scene to cover areas of the tunnels that might collapse. In the event that a fire resulted in the collapse of the tunnels, a recovery plan will be developed in accordance with emergency response procedures included in WHC-IP-0263-202A, Emergency P7 an for PUREX 
Facility. The recovery plan will take into consideration plans, if any, for retrieval of the waste stored within the tunnels.

Depending on the magnitude of a natural phenomena event or an explosion, damage to the storage tunnels is possible. The hazards could involve personnel and environmental exposure to mixed waste.

Additional emergency responses for fires and explosions can be found in DOE/RL-93-75, Hanford Facility Contingency Plan or in WHC-IP-0263-202A, Emergency Plan for PUREX Facility.

For classification of fires and/or explosions, refer to the facility specific recognition and classification procedure in WHC-CM-4-43, Emergency Management Procedures. If the event does not meet emergency classification criteria, continue following facility-specific response and reporting procedures.

\subsection{SEISHIC EVENT}

Depending on the magnitude of the sejsmic event, damage to the storage tunnels is possible. The hazards could involve personnel and environmental exposure to mixed waste.

Emergency responses for seismic events can be found in WHC-IP-0263-202A, Emergency Plan for PUREX Facility.

For classification of seismic events, refer to the facility-specific recognition and classification procedure in $\mathrm{HHC}-\mathrm{CM}-4-43$, Emergency Management Procedures. If the event does not meet emergency classification criteria, continue following facility specific response and reporting procedures.

\subsection{AIRCRAFT CRASH}

In addition to the potential for serious injuries or fatalities involved with an aircraft crash, damage to the storage tunnels is possible, which could result in a fire, explosion, or a mixed waste release.

Emergency responses for fires, explosions, and dangerous and/or mixed waste releases can be found in DOE/RL-93-75, Hanford Facility Contingency P7an or in WHC-IP-0263-202A, Emergency Plan for PUREX Facility.

For classification of fire, explosion, and dangerous and/or mixed waste release events, refer to the facility specific recognition and classification procedure in WHC-CM-4-43, Emergency Management Procedures. If the event does not meet emergency classification criteria, continue following facility-specific response and reporting procedures.

\subsection{BOMB THREAT/EXPLOSIVE DEVICE}

Depending on the magnitude of an explosion, damage to the storage tunnels is possible. The hazards could involve personnel and environmental exposure to mixed waste. Refer to Section 3.2 for emergency responses for explosions. 
For classification of bomb threat situations, explosions, and mixed waste release events, refer to the facility specific recognition and classification procedure in WHC-CM-4-43, Emergency Management Procedures. If the event does not meet emergency classification criteria, continue following facilityspecific response and reporting procedures.

\subsection{DAMAGED DANGEROUS AND/OR MIXED WASTE SHIPHENT}

In the event that a mixed waste shipment is damaged or otherwise presents a hazard to the public health and the environment, the damaged shipment should not be moved. Emergency responses for damáged waste shipments can be found in DOE/RL-93-75, Hanford Facility Contingency Plan.

\subsection{UNIT/BUILDING EMERGENCY RESPONSE PROCEDURES}

The initial response to any emergency is to immediately protect the health and safety of persons in the area. Identification of released material is essential to determine appropriate protective actions. Containment, treatment, and disposal assessment are secondary responses.

The preceding sections describe the process for implementing basic protective actions as well as descriptions of response actions for events.

The credible emergency events associated with the storage tunnels are listed in the event recognition and classification procedure for the PUREX Facility in WHC-CM-4-43, Emergency Management Procedures.

\subsection{NOTIFICATION (G-4a)}

Procedures and methods for immediate notification following an imminent or actual emergency are found in the WHC-IP-0263-202A, Emergency Plan for PUREX Facility.

\subsection{IDENTIFICATION OF RELEASED/SPILLED MATERIALS}

Methods for identifying the character, source, amount, and areal extent of any materials when there has been a release or spill to the environment, a fire, or an explosion is outlined in DOE/RL-93-75, Hanford Facility Contingency P7an.

\subsection{HAZARD ASSESSNENT AND REPORT}

The Building Emergency Director (BED) will assess the possible hazards to human health and the environment that might result from a fire, a release, a spill, or an explosion, considering direct, indirect, immediate, and long-term effects as outlined in DOE/RL-93-75, Hanford Facility Contingency Plan.

Procedures and methods for immediate notification following an emergency are found in Section 4.1 . 


\subsection{PREVENTION OF RECURRENCE OR SPREAD OF FIRES, EXPLOSIONS, RELEASES}

The BED, in coordination with emergency response organizations, takes the steps necessary to ensure that a secondary release, fire, or explosion does not occur. The following actions are taken:

- Isolate the area of the initial incident by shutting off power, closing off ventilation systems, if still operating, etc., to minimize the spread of a release and/or the potential for a fire or explosion

- Inspect surface of the tunnels for leaks, cracks, or other damage

- Contain and isolate residual mixed waste material

- Cover or otherwise stabilize areas where residual released mixed waste remains to prevent migration or spread from wind or precipitation run-off

- Install new structures, systems, or equipment to enable better management of mixed waste

- Reactivate adjacent operations in affected areas oniy after cleanup of residual mixed waste is achieved.

\subsection{POST-EMERGENCY ACTIONS (G-4f)}

It is a function of the BED (Emergency Coordinator) to declare the termination of an event. However, in an event where additional emergency centers are activated only the highest activated level of the emergency organization, in conjunction with the BED, will declare that an event has ended.

\subsection{EMERGENCY EQUIPMENT (G-5)}

Because personnel only enter the storage tunnels during material placement operations, no permanent emergency equipment, communications equipment, warning systems, personal protective equipment, or spill control and containment supplies are located in the tunnels.

During storage tunnel operations, personnel use portable emergency equipment such as two-way radios, flashlights, and personnel protective equipment. Also, for such operations, work plans are written and followed and pre-job safety meetings take place.

\subsection{COORDINATION AGREEMENTS (G-6)}

The DOE-RL has established a number of coordination agreements, or memoranda of understanding (MOU) with various agencies to ensure proper response resource availability for incidents involving the Hanford Site. A description of the agreements is contained in DOE/RL-93-75, Hanford Facility Contingency Plan. 


\subsection{EVACUATION (G-7)}

Personnel that enter the storage tunnels during material placement operations will evacuate via the north end of the raifroad tunnel, through the pedestrian door (Figure 1).

\subsection{REQUIRED REPORTS (G-8)}

Three types of written post-incident reports are required for incidents on the Hanford Site. The reports are summarized in DOE/RL-93-75, Hanford Facility. Contingency Plan. 


\subsection{REFERENCES}

DOE/RL-93-75, Hanford Facility Contingency P7an, U.S. Department of Energy, Richland, Washington.

WHC-CM-4-43, Emergency Management Procedures, Westinghouse Hanford Company, Richl and, Washington.

WHC-IP-0263-202A, Emergency Plan for PUREX Facility, Westinghouse Hanford Company, Richland, Washington. 
DOE/RL-90-24, Rev. 2

\section{APPENDIX $8 \mathrm{~A}$}

DANGEROUS WASTE TRAINING PLAN FOR THE PUREX FACILITY 
D0E/RL-90-24, Rev. 2

$11 / 95$

This page intentionally. left blank. 


\section{DANGEROUS WASTE TRAINING PLAN for the PUREX FACILITY. . .}

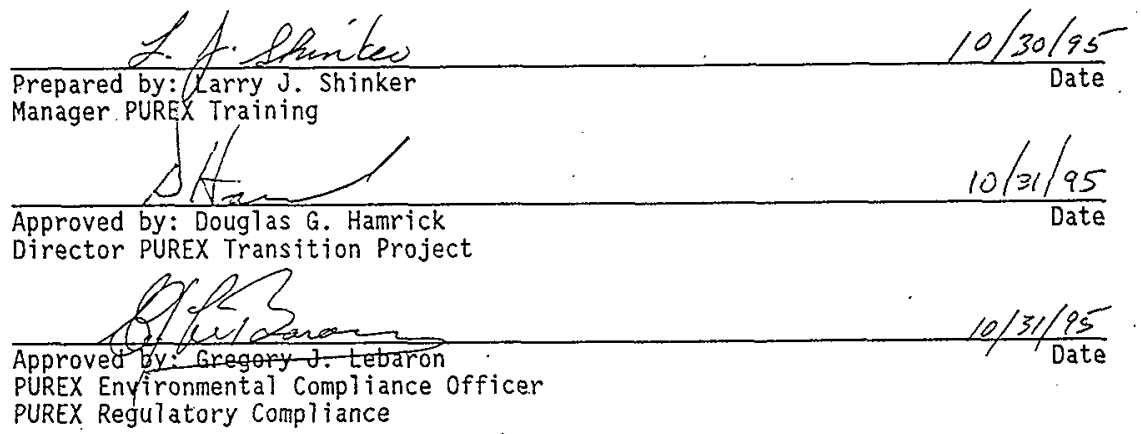




\subsection{INTRODUCTION}

In accordance with Washington Administrative Code (WAC), Chapter 173303, "Dangerous Waste Regulations;" a written training plan is required for many types of RCRA Waste Management Units. PUREX manages RCRA Waste Management Units regulated as generator units under WAC 173-303-200, and interim status units regulated under WAC 173-303-400. RCRA Waste Management Units covered by this pian include:

- Less than 90 day Accumulation Areas

- Haste Treatment and Storage Vessels

- Containment Building

- Storage Tunnels

WAC 173-303-200, and -400 require compliance with WAC 173-303-330, Personnel Training. This training plan complies with WAC 173-303-330. This training plan may be given to a reguiatory agency inspector upon request provided this $\mathrm{plan}$ is cleared for public release. Training records associated with personnel identified in this plan and maintained in the PUREX Regulatory file may be provided to an outside regulatory agency inspector as a result of the Federal Register Notice released on April 11, 1994 (59 FR 17091).

\subsection{TRAINING PROGRAM}

A dangerous or mixed waste generator and the owner/operator of active interim status units shall provide personnel training as directed by WAC 173-303-330. Centralized training organizations are responsible for developing the overall Hanford Facility training program of classroom instruction and maintaining training records. The plant manager is responsible for developing a program for unit/building-specific training supplementing the general Hanford Facility classroom program. General requirements of a training program include:

a. Instructing personnel to perform duties in compliance with the Dangerous Waste Regulations, WAC 173-303.

b. Instruction by a person knowledgeable of dangerous waste management procedures that includes training relevant to the employee's position.

c. A unit/building-specific program that includes instruction to familiarize personnel with applicable procedures (inspection plans, operating procedures, etc.), container management practices, spill response, and emergency procedures. Refresher training must be given annually to personnel. An annual review of the contingency plan and the emergency procedures maintained at the unit/building will satisfy the spill response and emergency procedures review.

d. New employees must receive training within 6 months of employment or transfer, and must be supervised until completion of training. 
e. Employees must receive appropriate annual refresher training.

\subsection{TRAINING PLAN CONTENT REQUIREMENTS}

In accordance with the requirements in WAC 173-303-330(2), a training plan must contain the following:

1. For each position related to dangerous waste management at the facility, the job title, the job description, and the name of the employee filling each job. The job description must include the requisite skills, education, other qualifications, and duties for each position.

2. A written description of the type and amount of both introductory and continuing training required for each position.

3. Records documenting that facility personnel have received and completed the training required by this section.

The following three sections describe how these requirements are met for PUREX.

3.1 Job Title, Job Description, and Names of Employees

Personnel who are associated with dangerous waste management at PUREX are maintained in this training plan by name in Appendix $A$. Personnel are placed into the following five general worker categories to properiy assign the correct training that is commensurate with their duties and responsibilities. Personnel duties and responsibilities may overlap between categories. When overlaps occur, personnel will complete appropriate training pertaining to courses applicable from each category. The determining factor for placing specific personnel within any of the worker categories is the corresponding job duties. The five worker categories are as follows:

1. All Employees

2. General Worker

3. Advanced General Worker

4. General Manager

5. General Shipper

The duties corresponding to these categories are contained in Tabie 1. The descriptions of job duties for each category are general in nature. However, the descriptions do provide adequate specifics that can be matched to individual job titles or job positions commonly found at the Hanford Facility. The responsibilities for personnel categorized as Advanced General Worker, General Manager, and General Shipper are provided since these categories are directly associated with the safe and compliant management of dangerous and mixed waste at PUREX. Since 
personnel categorized as All Employees and General Workers are not directly related to the safe and compliant management of dangerous and mixed waste at PUREX, these personnel are not maintained by name in Appendix $A$

All personnel are assigned a job title (from the salaried nonexempt or bargaining unit classifications) or position (from the exempt ciassifications). The job or position descriptions include applicable requisite skills, work experience, education, and other qualifications, and a brief list of duties and/or responsibjlities for each job title or position. Information regarding work experience, education, and other qualifications required for each position is maintained by Westinghouse Hanford Human Resources Department.

Personnel Assigned duties as a Dangerous Waste Worker will be removed from that assignment if their training goes delinquent. upon requalification they may resume previously assigned duties. 
Table 1. Worker Categories

\begin{tabular}{|c|c|c|}
\hline 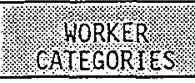 & 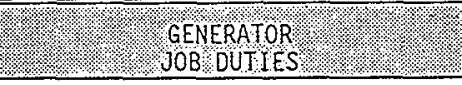 & PERSONNE \\
\hline ALL EMPLOYEES & $\begin{array}{l}\text { Is not categorized as a General Worker, } \\
\text { Advanced General Worker, General Manager, or } \\
\text { General Shipper. }\end{array}$ & $\begin{array}{l}\text { Administrative personnel } \\
\text { Touring visitors } \\
\text { Oversight personnel }\end{array}$ \\
\hline GENERAL WORKER & $\begin{array}{l}\text { Generates dangerous waste and places waste } \\
\text { into appropriate containers. Waste } \\
\text { management activities are overseen by } \\
\text { person-in-charge or other puREX personnel. } \\
\text { Contingency plan duties are to immediately } \\
\text { evacuate incident area and report incident } \\
\text { to appropriate personnel. Duties and } \\
\text { responsibilities would not exceed those } \\
\text { stated above. }\end{array}$ & $\begin{array}{l}\text { Maintenance personnel } \\
\text { Health physics technicians } \\
\text { Contractor erafts } \\
\text { Truck drivers } \\
\text { Power Operators }\end{array}$ \\
\hline $\begin{array}{l}\text { ADVANCED } \\
\text { GENERAL WORKER }\end{array}$ & $\begin{array}{l}\text { Duties, include the management of dangerous } \\
\text { waste in tanks, containers, containment } \\
\text { buildings, and storage tunnels. Selects, } \\
\text { packages, and prepares containers of } \\
\text { dangerous waste for movement including } \\
\text { proper marking and labeling of containers. } \\
\text { Performs inspections and operates the RCRA } \\
\text { Unit. Samples containers of dangerous waste } \\
\text { and prepares samples for delivery to a } \\
\text { laboratory. Contingency plan duties include } \\
\text { responding to small spills in accordance } \\
\text { with procedures within plans. }\end{array}$ & $\begin{array}{l}\text { Operators } \\
\text { Laboratory Technicians }\end{array}$ \\
\hline GENERAL MANAGER & $\begin{array}{l}\text { Environmental Compliance officer. Someone } \\
\text { who can act as the Building Emergency } \\
\text { Director, or someone who directs Advanced } \\
\text { General workers in accumulation of dangerous } \\
\text { waste. Responsible for the accountability } \\
\text { and directing of employees during dangerous } \\
\text { waste emergency events. }\end{array}$ & $\begin{array}{l}\text { Building Emergency Director } \\
\text { Manager of Advanced General } \\
\text { Worker } \\
\text { Environmental Compliance } \\
\text { Officer }\end{array}$ \\
\hline GEHERAL SHIPPER & $\begin{array}{l}\text { Duties include the preparation and shipment } \\
\text { of dangerous or mixed waste containers in } \\
\text { compliance with applicable requirements. } \\
\text { Directs General and Advanced General Workers } \\
\text { in dangerous waste management and/or } \\
\text { transportation activities. Authorized } \\
\text { individual for signing offsite waste } \\
\text { manifests and onsite waste movement } \\
\text { documentation. }\end{array}$ & $\begin{array}{l}\text { Hazardous Material Specialist } \\
\text { Waste Cognizant Engineer }\end{array}$ \\
\hline
\end{tabular}

1 Duties and responsibilities of personnel must be compared to the table. 
WESTINGHOUSE HANFORD COMPANY

PUREX FACILITY

STAFFING/TRAINING PLAN
Manual KHC-IP-0929 Rev. 2

Page 6 of 18

Date $10 / 16 / 95$

In general, all personnel require a high school diploma or General Equivalent Diploma. Personnel filling exempt management or engineering positions may require a college degree with. 2. or more years of industry experience. Many prerequisites exist for these positions. In some cases, a college degree may be waived as a prerequisite requirement. An equivalent combination of education and experience also may be accepted. Additional information on specific prerequisites can be provided upon request. The following sections describe within the appropriate worker category, the job titles and a brief position description of personnel at PUREX who are categorized as Advanced General Workers, General Managers, and General Shippers.

\subsubsection{PUREX Advance General Workers}

\subsubsection{PUREX Operators}

Responsibilities of operators include the following:

- Perform work activities in accordance with current operating procedures

- Perform sampling as required by procedure

- Conduct routine surveillance of waste treatment and storage. vessels, containment buildings and storage tunnels

- Respond to alarms, dangerous waste leaks or spills

- Respond to off-normal and/or emergency conditions according to established procedures

Responisibilities of PUREX Container Management Operators include the following:

- Receive, segregate, sort, inventory, store, and stage dangerous waste

- Provide surveillance of less than 90-day accumulation areas for off-normal conditions.

- Assist truck drivers in loading and untoading

- Ensure that trucks transporting dangerous waste are properly placarded

- Respond to dangerous waste leaks or spills

- Ensure that the waste has been properly secured in the transportation vehicle. 
- Receive, segregate, sort, inventory, store, and stage dangerous waste

- Provide survejllance of less than.90-day accumulation areas for off-normal conditions.

- Assist truck drivers in loading and unloading

- Ensure that trucks transporting dangerous waste are properiy placarded

- Ensure that the waste has been properly secured in the transportation vehicle.

\subsubsection{PUREX General Managers}

\subsubsection{PUREX Emergency Coordinator/Aiternates}

Responsibilities and duties of the Emergency Coordinator and the alternates include the following:

- Function as the Emergency Coordinator as defined in WAC 173-303-360.

- Determine if a RCRA contingency plan has been implemented during the course of an incident or process upset.

- Ensure all reports to Ecology have been made after an incident or process upset has occurred.

- Become thoroughly familiar with the RCRA Waste Management Units Contingency Plan, operations, activities, location and properties of all wastes handled, location of all records, and the layout of the RCRA Waste Management Units

\subsubsection{PUREX Environmental Compliance officer.}

Responsibilities include the following:

- Provide support management to ensure compliance with the applicable environmental compliance requirements, environmental permits, and compliance orders

- Ensure that management is aware of the RCRA Waste Management Units's environmental compliance status and environmental compliance activities

- Understand and be able to explain the environmental compliance status of the RCRA Waste Management Units with all applicable environmental requirements 
WESTINGHOUSE HANFORD COMPANY

PUREX FACILITY

STAFFING/TRAINING PLAN
Manual WHC-IP-0929 Rev. 2

Page 8 of 18

Date $10 / 16 / 95$

- Advise management of new environmental requirements and poljcies, the associated impacts, and recommended implementation mechanisms to ensure compliance

\subsubsection{PUREX General Shipper}

\subsubsection{Hazardous Material Specialist}

- Responsible to provide technical direction for handling, storage, transportation, and disposal of hazardous materials/wastes

- Direct general and advanced general workers in dangerous waste management and/or transportation activities

- Signing waste manifests and other waste movement documentation

- Perform weekly inspections of 90-day and satellite accumulation areas

- Oversee RCRA sampling of contaminated waste

\subsubsection{Waste Cognizant Engineer:}

- Lead responsibility to provide technical direction, for handling, storage hazardous materials/waste

- Direct general and advanced waste worker activities

- Direct/Coordinate RCRA sampling for containerized waste

- Write/Implement plant operation procedures for the proper handling, storage, and disposal of solid waste

- Provide direction for response to dangerous waste leaks or spills

\subsection{Written Description of the Type and Amount of Training}

Based on the categorization of personnel to the worker categories, the appropriate courses are chosen. Below is a list of available courses that may be assigned as a requirement by worker category. To help ensure the correct course is assigned. The list provides the course descriptions containing additional information about the course. Courses applicable to all personnel categorized as Advanced General Workers, General Managers, and General Shippers are listed in Appendix A for each employee by name. 


\subsubsection{Worker Category Courses}

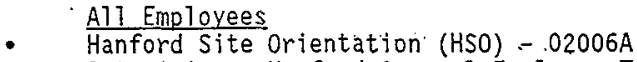

Retraining: Hanford General Employee Training (HGET) - 000001 Visitor/Vendor 01010000090

General Workers

- Hazard Communication and Waste Management Awareness - 02006G Retraining: $N / A$ - one time only

- Unit/building-specific contingency plan training (training waived when escorted by qualified PUREX personnel) - 03 E024 Retraining: 12 Months

Advanced General Workers, General Manaqers, General Shippers

- Courses are identified in Appendix A.

\subsubsection{Emergency Response Training}

Federal and state regulations require that personnel be able to respond effectively to emergencies. In accordance with WAC 173-303-330(1)(d), personnel are trained on emergency equipment, systems, and procedures. PUREX operations involve the management of dangerous waste within containers, tanks, containment building, and storage tunnels. Table 2 indicates requirements from WAC 173-303-330(1)(d) that are applicable to each RCRA Unit operation. Specific topics required by federal and state dangerous waste regulations are included in courses taught at the Hanford Facility. The courses cover a wide spectrum of target audiences. For example, some courses address the level appropriate for All Employees. At the other end of the spectrum, some of these courses concern responsibilities of General Managers who function as the emergency coordinator as defined in WAC 173$303-360$. 
Table 2. Applicability of WAC 173-303-330(1)(d) to RCRA Waste Management Units

\begin{tabular}{|c|c|c|c|c|}
\hline l. & 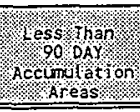 & STSTERS & 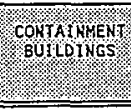 & 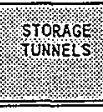 \\
\hline $\begin{array}{l}\text { Procedures for using, } \\
\text { inspecting, repairing, and } \\
\text { replacing emergency and } \\
\text { monitoring equipment }\end{array}$ & $Y$ & $\gamma$ & $Y$ & $Y$ \\
\hline $\begin{array}{l}\text { Key parameters for automatic } \\
\text { waste feed cut-off systems }\end{array}$ & $N$ & $Y$ & $N$ & $\mathbb{N}$ \\
\hline Communications or alarm systems & $Y$ & $Y$ & $Y$ & $Y$ \\
\hline Response to fires or explosions & $Y$ & $Y$ & $Y$ & $Y$ \\
\hline $\begin{array}{l}\text { Response to groundwater } \\
\text { contamination incidents }\end{array}$ & $N$ & $Y$ & $N$ & $N$ \\
\hline Shutdown of operations & $\mathbf{N}$ & $Y$ & $Y$ & $N$ \\
\hline
\end{tabular}

\subsubsection{Operator Certification Packages}

To ensure personne? are property trained in PUREX Facility Deactivation and Operation, certifications for specific work assignments have been created. Not every certification offered for PUREX operators is based upon Dangerous or Mixed Waste Management. Only the certifications that are based on Dangerous and Mixed Waste Management are included in this training plan. Of the five certification packages developed, only two are applicable to this plan, and include Course 250050, Deactivation Operations, and Course 250020, PUREX Solid Waste Management. Areas such as systems surveillance, alarm emergency response, spill control, waste tank system operations and equipment are addressed to meet the requirements of Section 3.2.2, Emergency Response Training.

\subsection{Training Records}

\subsubsection{Location of Training Records}

Training records, as described in WAC 173-303-330, consist of documentation that shows training has been completed. Hanford Facility training records include both electronic data storage and hard copies. The electronic data storage information is the training record initially presented to demonstrate that personnel have been trained. After a course is completed, the electronic data storage record is created on the Training Record Information (TRI) system. 
The electronic data storage record will contain the course number, course title, date of attendance, and any refresher dates. Hard copies of training records that are sent to the training record organization. for entry on the TRI System are initialiy maintained in Richland, Washington. Original hard copy training records are transferred quarterly to the Records Holding Facility in Richland, Washington. After approximately 1 year, the original hard copy training records are archived at the permanent record storage center in Renton, Washington. Electronic data storage and hard copy training records of former employees are kept for at least 3 years from the date the employee last worked at PUREX.

\subsubsection{Access of Training Records}

When a training record is requested during an inspection, an electronic data storage record will initially be provided. When the electronic data storage record does not satisfy the inspection concern, a hard copy training record will be provided. Training records of former employees may not be availabie through computers at PUREX and may require a representative from the Training Records organization to access the TRI System for this information.

\subsubsection{Determining Current Training Status}

After an electronic data storage training record is obtained, it will be compared to information in this plan. This plan can be used to determine the RCRA training status of all personnel in relation to all worker categories identified in this plan. The electronic data storage training record coupled with this training plan will give any inspector the ability to quickly determine the training status of personnel in the field.

\subsection{UPDATING THE TRAINING PLAN}

When new courses become available, this training $p l a n$ will be revised. When personnel are no longer working at PUREX, Attachment $A$ to this Training Plan wil] be updated to indicate new personnel and to remove those workers which are transferred to other areas. PUREX Training will update the Appendix $A$ on a quarterly basis. When the Emergency Coordinators change (i.e., BED), Emergency Preparedness will also be contacted to ensure the 1 ist of Emergency Coordinators is properiy maintained. 


\subsection{RCRA COURSE DESCRIPTIONS}

The following list of courses are driven by the requirements of the Washington Administrative Code 173-303; Dangerous Waste Regulations and WA7890008967, Hanford Facility RCRA Permit. Appendix A includes personnel in the applicable worker categories, $(3,4$, or 5 ) and the training courses applicable for their responsibilities. This attachment is updated quarteriy.

\section{COURSE NUMBERS COURSE TITLES}

000001 . Hanford General Employee Training

000090

$02006 \mathrm{~A}$

Visitor/Vendor 01010

$02006 \mathrm{G}$

Hanford Site Orientation

$02028 B$

Hazard Communication and Waste Management Awareness

03 E024

Building Emergency Director Training

Unit/Building-specific contingency plan training -

PUREX Facility

$035010 \quad$ Waste Designation Support

035020

Facility Waste Sampling and Analys is

035040

Environmental Regulations at Hanford

035050

Environmental Compliance at Hanford

035100

Core Waste Management Training - Initial

035110

Core Waste Management Training - Requalification

035120

Waste Management Administrative - Initial

035130

Waste Management Administrative - Requalification

037510

250020

Building Emergency Director Requalification

250050

PUREX Solid Waste Management

250700

PUREX Deactivation Operations

PUREX Facility Orientation

\begin{tabular}{|c|c|}
\hline ritle & 000001 Hanford General Employee Iraining \\
\hline Description & $\begin{array}{l}\text { Course covers DoE orders and applicable policies pertaining to employer } \\
\text { and employee rights and responsibilities, general radiation training, } \\
\text { hazard communications, dangerous waste, fire prevention, personal } \\
\text { protective equipment, safety requirements, certain unit/building } \\
\text { orientation refresher training, emergency preparedness, accident } \\
\text { reporting, and avenues for addressing safety concerns. }\end{array}$ \\
\hline Mandating Document(s) & Hanford Facility RCRA Permit, General Conditions II.C. 4 \\
\hline Target Audience & All Kanford Facility personnel \\
\hline Delivery & Computer-based training with interactive video \\
\hline Evaluation & Computer generated questions \\
\hline Length & Average $=2$ to 6 hours \\
\hline Frequency & Annual \\
\hline
\end{tabular}




$\begin{array}{ll}\text { WESTINGHOUSE HANFORD COMPANY } & \text { Manual WHC-IP-0929 ReY. } 2 \\ \text { PUREX FACILITY } & \text { Page } 13 \text { of } 18 \\ \text { STAFFING/TRAINING PLAN } & \text { Date } 10 / 16 / 95\end{array}$

\begin{tabular}{|c|c|}
\hline Title & 000090 Visitor/Vendor Video \\
\hline Description & $\begin{array}{l}\text { Course is designed to acquaint and familiarize visitors and subcontractors } \\
\text { with safety, security, and emergency preparedness requirements and their } \\
\text { responsibilities to notify Hanford Facility personnel when situations } \\
\text { arise. In addition, this orientation identifies the need to obey signs } \\
\text { and labels that may be encountered regarding radiological areas, hazardous } \\
\text { materials, and dangerous waste. }\end{array}$ \\
\hline Mandating Oocument(s) & Hanford Facility RCRA Permit HA7890008967, General conditions $11 . C .4$ \\
\hline Target Audience & Visitors/vendors/subcontractors \\
\hline Delivery & Video tape \\
\hline Evaluation & Not Appl icable \\
\hline Length & 15 minutes \\
\hline Frequency & Annual \\
\hline
\end{tabular}

\begin{tabular}{|c|c|}
\hline ritle & 02006A Hanford site Orientation \\
\hline Description & $\begin{array}{l}\text { Course covers DOE orders and applicable policies pertaining to employer and } \\
\text { employee rights and responsibilities, general radiation. training, hazardous } \\
\text { waste, fire prevention, personal protective equipment, safety requirements, } \\
\text { accident reporting, and avenues for addressing safety concerns. }\end{array}$ \\
\hline Mandating Document(s) & Hanford Facility RCRA Permit, General Condition 11.C. 4 \\
\hline Target Audience & All Hanford Facility personnel \\
\hline Delivery & Classroom \\
\hline Evaluation & Not applicable \\
\hline Length & 3 hours \\
\hline Frequency & Initial (Retrained annually by 000001 HGET) \\
\hline
\end{tabular}

\begin{tabular}{|c|c|}
\hline Title & 020066 Hazard Cormunication and Waste Management Awareness \\
\hline Description & $\begin{array}{l}\text { Course introduces workers to federal laus governing chemical safety in the work } \\
\text { place. The course provides the hazardous material/waste worker with the basic } \\
\text { fundamentals for safe use and disposal of hazardous material. Course defines } \\
\text { hazard commication and hazardous material, reviews label ing requirements, and } \\
\text { introduces material safety data sheets and key terms used in chemical safety. } \\
\text { The course also introduces methods for waste minimization. }\end{array}$ \\
\hline Mandating Document(s) & WAC $173-303-200(2)$ \\
\hline Target Audience & $\begin{array}{l}\text { Hanford Facility personnel categorized as a General Horker, Advanced General } \\
\text { Worker, General Manager, and General Shipper }\end{array}$ \\
\hline Delivery & Classroon \\
\hline Evaluation & Written examination - $80 \%$ passing grade \\
\hline Length & 4 hours \\
\hline Frequency & $H / A$ - One time only \\
\hline
\end{tabular}




\begin{tabular}{ll}
\hline \hline WESTINGHOUSE HANFORD COMPANY & Manual WHC-IP-0929 Rev. 2 \\
PUREX FACILITY & Page 14 of 18 \\
STAFFING/TRAINING PLAN & Date $10 / 16 / 95$
\end{tabular}

\begin{tabular}{|c|c|}
\hline Title & 02028B Building Emergency Director Training \\
\hline Description & $\begin{array}{l}\text { Course provides an overview of the responsibilities of the building emergency } \\
\text { director, identifies the building emergency organizations, actions required } \\
\text { during an event, implementing the contingency plan, and discusses driti and } \\
\text { exercise requirements. }\end{array}$ \\
\hline Mandat ing Document (s) & WAC $173-303-340,-350$, and -360 \\
\hline Target Audience & $\begin{array}{l}\text { Building Emergency Directors and their alternates who can function as the } \\
\text { Emergency Coordinator }\end{array}$ \\
\hline Delivery & Classroom \\
\hline Evaluation & Not Applicable \\
\hline Length & 2 hours \\
\hline Frequency & $\begin{array}{l}\text { Initial (Retrained annually by } 037510 \text { Building Emergency Director/warden } \\
\text { Requalification) }\end{array}$ \\
\hline
\end{tabular}

\begin{tabular}{|c|c|}
\hline Title & 03E024 Unit/building-Specific Contingency Plan Training- PUREX Facility \\
\hline Description & $\begin{array}{l}\text { Course consists of a review of specific hazards associated with the RCRA Waste } \\
\text { Management Units, as covered by the contingency plan (WHC-IP-0263-202A). The } \\
\text { training is completed by the supervisor, manager, or a designated individual } \\
\text { using a checklist. The unit/building-specific information is reviewed } \\
\text { concerning hazards in the work area and emergency response requirements, } \\
\text { including where applicable, waste feed cut-off, commication and alarm } \\
\text { systems, and response to fires. The checklist acts as a guide to ensure } \\
\text { consistent coverage of necessary topics. }\end{array}$ \\
\hline Mandating Document(s) & WAC $173-303-330(1)(d),-340$, and -350 \\
\hline Target Audience & $\begin{array}{l}\text { All Hanford Facility personnel categorized as Advanced General Horkers, Generat } \\
\text { Managers, and General Shippers. assigned to RCRA Waste Management Units. All } \\
\text { General Workers may take this course, or equivalent training may be given } \\
\text { during the pre-job safety meeting the General Worker may be escorted by } \\
\text { qualified RCRA Waste Management Units personnel. }\end{array}$ \\
\hline Delivery & One-on-one or as a group with supervisor, manager or designated individual \\
\hline Evaluation & Iraining checkl ist documentation \\
\hline Length & 1 hour \\
\hline Frequency & Annual \\
\hline
\end{tabular}




WESTINGHOUSE HANFORD COMPANY
PUREX FACILITY
STAFFING/TRAINING PLAN

Manual WHC-IP-0929 Rev. 2

Page 15 of 18

Date $10 / 16 / 95$

\begin{tabular}{|c|c|}
\hline Title & 035010 Waste Designation Support \\
\hline Description & $\begin{array}{l}\text { Course teaches dangerous waste designation according to waC } 173-303 \text {. Class } \\
\text { content includes section-by-section. lecture on the regulations, with examples } \\
\text { following each section. Students complete examples using a waste designation } \\
\text { flow chart. Examples addressed include: federal listed waste, discarded } \\
\text { chemical products, dangerous waste source, Washington state criteria: toxicity, } \\
\text { persistence, carcinogenic, and federal characteristics: ignitability. } \\
\text { corrositivity, reactivity, and toxicity. }\end{array}$ \\
\hline Mandating Document (s) & WAC 173.303 .070 , and -080 through -100 \\
\hline Target Audience & General Shippers \\
\hline Delivery & Classroom \\
\hline Evaluation & Written Exam - $80 \%$ passing grade \\
\hline Length & 12 Hours \\
\hline Frequency & Annual \\
\hline
\end{tabular}

\begin{tabular}{|c|c|}
\hline Title & 035020 Facility Waste Sampling and Analys is \\
\hline Description & $\begin{array}{l}\text { Course presents waste sampling methodologies according to EPA Protocols } \$ H-846 \text {, } \\
\text { Test Methods for Evaluating Solid Waste Physical/Chemical Methods. Ihis course } \\
\text { also covers documentation requirements in a sampl ing plan, field and laboratory } \\
\text { quality control/assurance, and use of actual sampling equipment. } \\
\text { One-time training is required because the General shipper, in most cases, will } \\
\text { utilize resources on the Hanford Facility to acquire samples. This training } \\
\text { provides an overview of information to ensure that sampling efforts are } \\
\text { properly set up. }\end{array}$ \\
\hline Mandat ing Document(s) & WAC $173-303-110$ and -070 \\
\hline Target Audience & General shippers \\
\hline Delivery & Classroompresentation, exercises, demonstration and discussion \\
\hline Evaluation & Written Examination \\
\hline Length & 12 hours \\
\hline Frequency & One time only \\
\hline
\end{tabular}

\begin{tabular}{|c|c|}
\hline Title & 035040 Enviromental Regulations at Hanford \\
\hline Description & $\begin{array}{l}\text { This course provides an overvien of environmental regulations as they apply to } \\
\text { the Hanford Facility. This course helps enable participants to make informed } \\
\text { decisions relating to environmental compliance issues. It includes information } \\
\text { on potential legal liabilities, applicable federal and state regulations, } \\
\text { various reporting requirements, inspections/audits and record keeping. } \\
\text { information is presented using Hanford Facility examples. }\end{array}$ \\
\hline Mandating Document(s) & $\begin{array}{l}\text { WAC } 173-303-145 \text { and general overvies of certain } \\
\text { WAC } 173-303 \text { sections } \\
\text { Training covers disciplines from RCRA, NEPA, air regulations, EPCRA, TSCA, } \\
\text { spill reporting, and inspection considerations }\end{array}$ \\
\hline Target Audience & Level 1,11 , and 111 Managers \\
\hline Delivery & Classroom \\
\hline Evaluation & Hritten Examination - $80 \%$ passing grade \\
\hline Length & 8 hours \\
\hline Frequency & One rime only \\
\hline
\end{tabular}


WESTINGHOUSE HANFORD COKPANY

PUREX FACILITY

STAFFING/TRAINING PLAN
Hanual WHC-IP-0929 Rev. 2

Page 16 of 18

Date $10 / 16 / 95$

\begin{tabular}{|c|c|}
\hline Title & 035050 Environmental Comsliance at Hanford \\
\hline Description. & $\begin{array}{l}\text { Provides an overview of environmentat regulations and focuses on the use of } \\
\text { environmental compliance manuals to address compliance issues. Information is } \\
\text { presented through Hanford Facility examples. . }\end{array}$ \\
\hline Mandating Document (s) & $\begin{array}{l}\text { WAC } 173-303-145 \text { and general overview of certain } \\
\text { WAC } 173-303 \text { sections. } \\
\text { Training covers disciplines from RCRA, NEPA, air regulations, EPCRA, TSCA, } \\
\text { spill reporting, and inspection considerations }\end{array}$ \\
\hline Target Audience & $\begin{array}{l}\text { Environmental Compliance officers, General Managers who are level } 4,5 \text {, and } 6 \\
\text { managers }\end{array}$ \\
\hline Delivery & Classroom \\
\hline Evaluation & Workbook \\
\hline Length & 8 Hours \\
\hline Frequency & One Time Onty \\
\hline
\end{tabular}

\begin{tabular}{|c|c|}
\hline Title & 035100 Core Waste Management - Initial \\
\hline Description & $\begin{array}{l}\text { Course covers basic requirenents of waste management, incorporating } 40 \text { CFR, } \\
\text { WAC } 173-303 \text {, DOE Orders, and company policy. Includes three practical } \\
\text { exercises for hands-on experience wi th satellite and } 90 \text {-day accumulation area } \\
\text { requirements, labpacks for dangerous waste and mixed waste, and preparation of } \\
\text { packages for final destination. This course is intended to discuss } \\
\text { requirements for on site management practices of containerized dangerous waste. } \\
\text { This course is not intended to be a RCRA related course for General Shippers } \\
\text { who conduct off site waste shipments as defined by WAC } 173-303-040 \text {. }\end{array}$ \\
\hline Mandating Doctment(s) & HAC $173-303-630,-200$ and Waste Minimization \\
\hline Target Audience & $\begin{array}{l}\text { Advanced General Workers and General Managers of Advanced Generat Horkers who } \\
\text { manage containers of dangerous waste. } 90 \text {-day tank systems are not discussed in } \\
\text { this course. This course is recomended for General Shippers who ship } \\
\text { dangerous waste on site. }\end{array}$ \\
\hline Delivery & Classroom \\
\hline Evaluation & Written Examination - $80 \%$ passing grade \\
\hline Length & 16 Hours \\
\hline Frequency & $\begin{array}{l}\text { Initial (retrained annually by } 035110 \text { Core Waste Management Training - } \\
\text { Refresher) }\end{array}$ \\
\hline
\end{tabular}

\begin{tabular}{|l|l|}
\hline Title & 035110 Core Waste Managenent - Refresher \\
\hline Description & Refreshes Course 035100 \\
\hline Target Audience & Advanced General Workers and General Hanagers of Advanced General Workers \\
\hline Delivery & Classroom \\
\hline Evaluation & Written Examination - 80\% passing grade \\
\hline Length & 4 Hours \\
\hline Frequency & Annual \\
\hline
\end{tabular}




\begin{tabular}{|c|c|}
\hline Iitle & 035120 Waste Management Administration - initial \\
\hline Description & $\begin{array}{l}\text { Course is designed for personnel preparing to become authorized shippers of } \\
\text { dangerous and/or mixed waste. This course covers regulatory and company } \\
\text { policies, forms, reports, forecasts, and plans. Topics also covered include: } \\
\text { waste characterization, waste storage disposat request, low level waste } \\
\text { storage/disposal record, transuranic waste storage/disposal record, and } \\
\text { radioactive mixed waste attachment sheet. In addition, students will learn how } \\
\text { these forms are used to complete shipping papers. }\end{array}$ \\
\hline Mandatind Document(s) & Hanford Facility RCRA Permit, Part II, condition II.Q \\
\hline Target Audience & General Shippers \\
\hline Delivery & Classroom \\
\hline Evaluation & Written Examination - $80 \%$ passing grade \\
\hline Length & 8 Hours \\
\hline Frequency & $\begin{array}{l}\text { Initial (Retrained annulty by } 035130 \text { Waste Management Adninistration - } \\
\text { Refresher) }\end{array}$ \\
\hline
\end{tabular}

\begin{tabular}{||l|l|}
\hline Title & 035130 Waste Management Administration - Refresher \\
\hline Description & Refreshes course 035120 \\
\hline Target Audience & General Shippers \\
\hline Delivery & Classroom \\
\hline Evaluation & Written Examination $-80 \%$ passing grade \\
\hline Length & 4 Hours \\
\hline Frequency & Annual \\
\hline
\end{tabular}

\begin{tabular}{|l|l|}
\hline Titie & 037510 Building Emergency Director Requalification \\
\hline Description & Refresher for Bujlding Emergency Director Training \\
\hline Target Audience & Building Emergency Directors and al ternates \\
\hline Delivery & Classroon \\
\hline Evaluation & Not Appl icable \\
\hline Length & 2 hours \\
\hline Frequency & Annual \\
\hline
\end{tabular}




\section{WESTINGHOUSE HANFORD COKPANY \\ PUREX FACILITY \\ STAFFING/TRAINING PLAN}

Manual WHC-IP-0929 Rev. 2

Page 18 of 18

Date $10 / 16 / 95$

\begin{tabular}{|c|c|}
\hline Title & 250020 PUREX Solid Waste Management \\
\hline Description & $\begin{array}{l}\text { Course elements include Operators specific responsibitities with regards to the } \\
\text { safe and compliant packaging, storage, and shipnent of Dangerous and Mixed } \\
\text { Waste at PUREX. Information includes all applicable information covering } \\
\text { administration and use of Satellite Accumulation Areas and <90 Day Accumulation } \\
\text { Areas. Course atso includes elements of compliance with alt Federal, State, } \\
\text { Local, and DoE and WHC regulations governing the packaging and storage of } \\
\text { Dangerous and Mixed Wastes. }\end{array}$ \\
\hline Mandating Document (s) & WAC $173-303-330$ \\
\hline Target Audience. & Advanced General Workers (Operators and immediate Managers) \\
\hline Delivery & Classroom \\
\hline Evaluation & $\begin{array}{l}\text { Written examination - Operators-70\% passing grade, OJT, Job Performance } \\
\text { Measures/Managers Exam only, } 80 \% \text { passing grade. }\end{array}$ \\
\hline Length & 3 days \\
\hline Erequency & Every other year \\
\hline
\end{tabular}

\begin{tabular}{|l|l|}
\hline Title & 250050 PUREX Deactivation Operations \\
\hline Description & $\begin{array}{l}\text { Course elenents inctude Operators specific responsibilities with regards to the } \\
\text { safe and compl iant deactivation of pUREX Operating and } \\
\text { Emergency/Monitoring/Alarm Systems. }\end{array}$ \\
\hline Mandating Document(s) & WAC $173-303-330$ \\
\hline Target Audience & Operators and Operations Managers \\
\hline Delivery & $\begin{array}{l}\text { N/A - Self Study - Manual, OJT, Examination, Job Performance Measures } \\
\text { (Operational instruction. }\end{array}$ \\
\hline Evaluation & Written examination - Operators-70\% passing grade/Managers B0\% \\
\hline Length & W/A \\
\hline Frequency & Every other year \\
\hline
\end{tabular}

\begin{tabular}{|l|l|}
\hline Titie & 250700 PUREX Facility Orientation \\
\hline Description & $\begin{array}{l}\text { Course describes the general layout of the PUREX Facitity, as well as, some of } \\
\text { the general hazards employees may encounter, at various locations within the } \\
\text { Facility. }\end{array}$ \\
\hline Mandating Document(s) & WAC $173-303-330$ \\
\hline Target Audience & ALl PUREX Advanced Waste Workers, General Shippers and General Managers. \\
\hline Detivery & Comouter Based Training \\
\hline Length & 1 hour \\
\hline Frequency & Biennial \\
\hline
\end{tabular}




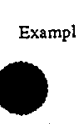

NAME
HGET

$000001-\mathrm{M}$ 12 MONTHS
HAZ COMMUN/WST
MGMT 02006G-M N/A
PUREX Ad Wst WK

CORE WASTE CORE WASTE PUREX BLDG MGMT INI

MGMT

REQUAL

035100-M

035110-M

12 Months

12 Months
EMER PLAN

03E024-M

12 Months
PUREX/UO3

WASTE

250020-P

24 Months
PUREX

DEACTV OPS

250050-P

24 Months
PUREX

FCLTY

ORIENT

250700-R

24 Months

\begin{tabular}{lllllllll} 
Employee 1 & $07 / 10 / 96$ & Complete & Complete & $02 / 17 / 97$ & $10 / 14 / 95$ & $02 / 17 / 97$ & N/A & $07 / 10 / 97$ \\
\hline Employee 2 & $05 / 05 / 96$ & Complete & Complete & $05 / 11 / 96$ & $06 / 29 / 96$ & N/A & $01 / 14 / 96$ & $05 / 23 / 97$ \\
\hline Employee 3 & $05 / 26 / 96$ & Complete & Complete & $10 / 07 / 96$ & $07 / 14 / 96$ & $10 / 07 / 96$ & $11 / 02 / 96$ & $05 / 26 / 97$ \\
\hline
\end{tabular}

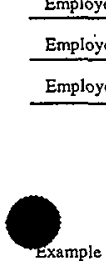

Example

\section{1-M}

NAME 12MONTHS

Employee 4

NAME

Employee 7

Employee

Employee 9

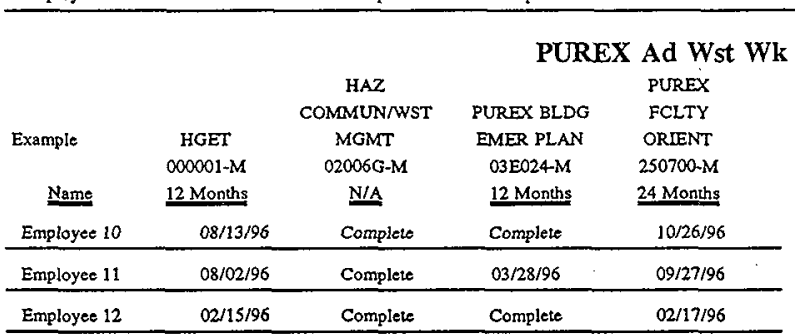

MGMT SUPPORT ANLYS INI

$035020-\mathrm{M}$

02006G-M .

12 Months

N/A

Complete

$11 / 14 / 95$

Complete

\section{PUREX Gen Mgrs}

\section{PUREX Gen Ships}

HAZ WASTE FCLTY WST WASTEMGMT WASTEMGMT PUREX BLDG PUREX COMMUNNYST DESJGNATION SAMPLE\& ADMIN ADMIN EMER PLAN FCLTY

035120-M

REQUAL

$035130-\mathrm{M}$

$03 E 024 M$

ORIENT

12 Months

12 Months

12 Months

250700-R

24 Months

$05 / 25 / 97$

Complete

$12 / 07 / 95$

$07 / 12 / 96$

$06 / 13 / 97$

Complete

$02 / 16 / 96$

$06 / 13 / 96$

$08 / 28 / 97$

HAZ ENVIRON- ENVIRON-

COMMUNNWT

HGET

$000001-\mathrm{M}$

12 MONTHS

MGMT

02006G-M

N/A

Complete

Complete

Complete

Compiete

BLDG EMER
DRR TRNG
O2O28B-P
12 MOnths

MENTAL

REGS

035040-P

MENTAZ

COMPLIANCE

035050-P

N/A

N/A

Complete

Complete

Complete

Nomplete

N/A Complete

N/A

N/A

BED REQUAL

037510-P

12 Months
PUREX BLDG

EMER PLAN

O3E024-M

12 Months
PUREX

FCLTY

ORIENT

250700-R

24 Months

$02 / 28 / 96 \quad 06 / 19 / 96 \quad 06 / 19 / 97$

$\begin{array}{lll}03 / 18 / 96 & 09 / 27 / 96 & 05 / 31 / 97\end{array}$

$02 / 28 / 96 \quad 10 / 26 / 96$

$09 / 14 / 96$

Keys:

\footnotetext{
$<<\quad>>$ An expired certification date.

Blank The course has never been obtained.

- The employes has been seheduled to attend this course.
} 


\section{DISTRIBUTION}

OFFSITE

MSIN

Washington State Department of Ecology

R. J. Julian*, Kennewick office

B5-18

M. N. Jaraysi*, Kennewick Office

B5-18

Joe Witczak*

P.0. Box 47600

01ympia, WA $98504-7600$

U.S. Environmental Protection Agency

D. R. Sherwood, EPA Region 10

B5-01

Confederated Tribes of the Umatilla Indian Reservation

J. R. Wilkinson*

P.0. Box 638

Pendleton, OR 98701

Nez Perce Tribe

D. Powaukee*

P.0. Box 305

Lapwai, ID 80540

Confederated Tribes and Bands

of the Yakama Nation

D. Dogsleep

G1-02

R. Jim*

P.0. Box 151

Toppenish, WA 98948

ONSITE

U.S. Department of Energy,

Richland Operations office

C. E. Clark (2)

A5-15

R. X. Gonzalez

R3-79

Public Reading Room* (2)

$\mathrm{H} 2-53$

MAC Technical Services Company

J. R. Markillie

B] -42 


\section{DISTRIBUTION (cont)}

Pacific Northwest Laboratory

Hanford Technical Library*

Westinghouse Hanford Company

C. R. Haas* (3)

S6-19

D. G. Hamrick

S6-15

D. G. Harlow

S6-19

G. J. LeBaron

S6-19

C. P. Strand

H6-24

Central Files*

L.8-04

EDMC* (2)

OSTI* (2)

H6-08

RCRA File (MWC)

E6-44

H6-23

* With aperture cards. 
STATE ENVIRONMENTAL POLICY ACT ENVIRONMENTAL CHECKLIST FORMS

FOR THE

PUREX STORAGE TUNNELS

SUPPLEMENT 1

NOVEMBER 1995

WASHINGTON ADMINISTRATIVE CODE ENVIRONMENTAL CHECKLIST FORMS

[WAC 197-11-960] 


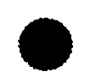

THIS PAGE INTENTIONALLY LEFT BLANK 
SEPA EnvironmentaT Checklist PUREX Storage Tunnels

Page 1 of 23

\section{A. BACKGROUND}

1. Name of proposed project:

Permitting of the Plutonium-Uranium Extraction (PUREX) Storage Tunnels. Information contained in this checklist pertains only to the PUREX Storage Tunnels [Tunnel Number 1 (218-E-14) and Tunnel Number 2 (218-E-15)]. In the context of the checklist, 'site' refers only to those areas that are immediately underlain by the underground storage tunnels.

2. Name of applicants:

U.S. Department of Energy-Richland Operations, and Westinghouse Hanford Company.

3. Address and phone number of applicant and contact person:

U.S. Department of Energy

Richland Operations office

P. 0. Box 550

Richland, Washington 99352

\section{Contact Persons:}

J. E. Rasmussen; Director

Office of Environmental Assurance, Permits, and Policy Division (509) $376-5441$
Westinghouse Hanford Company P.0. Box 1970

Richland, Washington 99352

4. Date checklist prepared:

November 1995

5. Agency requesting the checklist:

Washington State

Department of Ecology

Mail Stop PV-11

0lympia, WA 98504

6. Proposed timing or schedule (including phasing, if applicable):

The PUREX Storage Tunnels are two parallel branches of a railroad tunnel that extend southward from the east end of the PUREX PIant. Construction of Tunnel Number 1 was completed in 1956. Tunnel Number 1 was first used for storage of PUREX Plant process equipment in June 1960 and was filled to capacity in January 1965. Construction of Tunnel Number 2 was completed in 1964. Tunnel Number 2 was first used for storage in December 1967 and presently has storage positions available. 
SEPA Environmental Check1ist PUREX Storage Tunnels

Page 2 of 23

Closure of the PUREX Storage Tunnels as a dangerous waste treatment, storage, and/or disposal unit will take place in conjunction with the final disposition of the PUREX Plant.

7. Do you have any plans for future additions. expansion, or further activity related to or connected with this proposal? If yes, explain.

The PUREX Storage Tunnels will operate under the Hanford Facility RCRA Dangerous Waste Permit No. WA7890008967 until a determination is made that the tunnels are to be deactivated and closed.

8. List any environmental information you know about that has been prepared, or will be prepared, directly related to this proposal.

- This SEPA Environmental Checklist is being submitted as a part of the Hanford Faci7ity Dangerous Waste Permit Application, PUREX Storage Tunnels (DOE/RL-90-24, Revision 2).

- A RCRA Part A Dangerous Waste Permit Application, Form 3, for PUREX Storage Tunnels was submitted to the Washington State Department of Ecology (Ecology) in August, 1995.

- The PUREX Storage Tunnels are discussed in the following National Environmenta] Policy Act documentation: Environmental Impact Statement, Operation of PUREX and Uranium Oxide Plant Facilities, DOE/EIS-0089 (U.S. Department of Energy, 1983, Washington, D.C.).

- Tunnel Number 2 has an operating stack (296-A-10), which is registered with the Washington State Department of Health (DOH) for radionuclide emissions (Radionuclide Air Emissions Report for the Hanford Site, DOE/RL-95-49, U.S. Department of Energy, 1995, Richland, Washington). Tunnel Number 1 stack is not in operation and has been sealed. It is, therefore, not registered under the Clean Air Act of 1977.

Supplemental information on all registered PUREX PIant stacks was submitted to the DOH in State of Washington Department of Health, Radioactive Air Emissions Permit FFO1 Supplemental Information, DOE/RL-90-34 (U.S. Department of Energy, 1990, Richland, Washington).

Additional environmental information regarding the 200 Area plateau and the Hanford Site, in general, can be found in the following references:

- Final Environmental Impact Statement Disposal of Hanford Defense High-Leve7, Transuranic and Tank Wastes, DOE/EIS-0113 (U.S. Department of Energy, 1987, Richland, Washington)

- Hanford Site Nationàl Environmental Policy Act (NEPA) Characterization, Revision 7, PNL-6415 (Pacific Northwest Laboratory, 1995, Rich1and, Washington) 
SEPA Environmental Checklist PUREX Storage Tunnels

Page 3 of 23

- Draft Envirónmental Impact Statement Decommissioning of Eight Surp7us Production Reactors at the Hanford Site, Richland, Washington, D0E/EIS-0119D (U.S. Department of Energy, 1989, Washington, D.C.)

- Archaeological Survey of the 200 East and 200 West Areas, Hanford Site, Washington, PNL-7264 (Pacific Northwest Laboratory, 1990, Richland, Washington).

9. Do you know whether applications are pending for government approvals of other proposals directiy affecting property covered by your proposal? If yes, explain.

No applications are known to be pending for government approval of other proposals that would directiy affect property covered by this proposal.

10. List any government approvals or permits that will be needed for your proposal, if known.

Ecology, the Washington State Department of Health, and the U.S. Environmental Protection Agency are the only agencies authorized to approve and/or permit operation of the PUREX Storage Tunnels. under requirements authorized by RCRA, the Clean Air Act (42 USC 7401 et seq.), WAC 173-303, WAC 246-247, and WAC 173-401.

11. Give a brief complete description of your proposal, including the proposed uses and the size of the project and site.

The PUREX Storage Tunnels are used for storage of mixed waste from the PUREX PIant and from other onsite sources. Some of this material could contain varying amounts of dangerous waste that includes lead, mercury, silver and sitver salts, barium, selenium, cadmium, and chromium.

The PUREX Storage Tunnels are an extension of the rail spur on which irradiated reactor fuels were delivered to the PUREX PIant for chemical reprocessing. Each storage tunnel is isolated from the PUREX Plant railroad tunnel by a water-fillable shielding door. Material selected for storage in the tunnels is loaded onto modified railcars that serve as transport and storage platforms. Normally, a remote-controlled, battery-powered locomotive is used to position the railcar into the storage tunnel. In the past and possibly in the future, other remote movers, e.g., standard locomotive with a string of railcar spacers, power winch, etc., have been or could be used to position a railcar into the tunnel or withdraw a car from the tunnel.

Tunnel Number 1 is filled to capacity and contains eight railcars, positioned end to end along the length of the tunnel. The inside dimensions of Tunnel Number 1 are 109.1 meters long, 6.7 meters high, and 5.9 meters wide.

Tunnel Number 2 contains 21 railcars (as of August 1, 1995) and has the capacity to contain 40 railcars, end to end. The inside dimensions of 
SEPA Environmental Checklist PUREX-Storage Tunnels

Page 4 of 23

TO BE COMPLETED BY APPLICANT

\section{B. ENVIRONMENTAL ELEMENTS}

1. Earth.

a. General description of the site:

Gently sloping.

b. What is the steepest slope on the site (approximate percent slope)?

During construction, the soil overburden covering the PUREX Storage Tunnels was contoured to provide side slopes of 2 (horizontal) to 1 (vertical) (or 50 percent) for stability. The approximate slope of the 
Iand adjacent to the PUREX Storage Tunnels site is less than two percent.

c. What general types of soils are found on the site (for example, clay, sand, gravel, peat, muck)? If you know the classification of agricuiturat soils, specify them and note any prime farmland.

The soil at the site is coarse sand and gravel. No farming is allowed on the site.

d. Are there surface indications or history of unstable soils in the immediate vicinity? If so, describe.

No.

e. Describe the purpose, type, and approximate quantities of any filling or grading proposed. Indicate the source of the fill.

Does not apply.

f. Could erosion occur as a result of clearing, construction, or use? If so, describe.

No.

g. Approximately what percentage of the site will be covered with impervious surfaces after project construction (for example, asphalt or buildings)?

Does not apply.

h. Proposed measures to reduce or control erosion, or other impacts to the earth, if there are any?

Following construction, the soil overburden that covers the PUREX Storage Tunnels was contoured to a 2 to 1 slope for stability. Natural vegetation has been allowed to cover the tunnel mounds to minimize both wind and water erosion. 


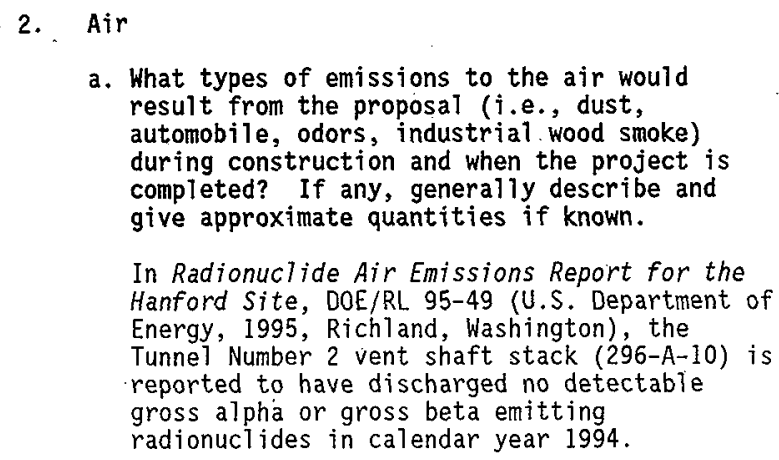

b. Are there any off-site sources of emissions or odors that may affect your proposal? If so, generally describe.

No.

c. Proposed measures to reduce or control

emissions or other impacts to the air, if any?

The PUREX Storage Tunnel Number 1 exhaust system was deactivated in January 1965 when the tunnel was filled to capacity. Presently, no ventilation is provided to Tunnel Number 1 as the exhaust vent has been blanked ahead of the filter housing.

Present]y, PUREX Storage Tunnel Number 2 has an operating stack (296-A-10) registered and permitted for radionuclide emissions with the DOH. Tunne 1 Number 2 stack could be operated continuously, or de-energized and reactivated during waste placement activities. The exhaust air from the tunnel stack is sampled periodically in accordance with established controls for radioactive airborne emissions. Collected particulates are analyzed for total alpha and total beta activity. The air sampler is inspected daily when operating. 
TO BE COMPLETED BY APPLICANT

EVALUATIONS FOR AGENCY USE ONLY

\section{Water}

a. Surface:

1) Is there any surface water body on or in the immediate vicinity of the site (including year-round and seasonal streams, saltwater, lakes, ponds, wetlands)? If yes, describe type and provide names. If appropriate, state what stream or river it flows into.

No.

2) Wi11 the project require any work over, in, or adjacent to (within 200 feet of) the described waters? If yes, please describe and attach available plans.

No.

3) Estimate the amount of fill and dredge material that would be placed in or removed from surface water or wetlands and indicate the area of the site that would be affected. Indicate the source of fill material.

None.

4) Will the proposal require surface water withdrawals or diversions? Give generai description, purpose, and approximate quantities if known.

No.

5) Does the proposal lie within a 100-year floodplain? If so, note location on the site plan.

No. 

6) Does the proposal involve any discharges of waste materials to surface waters? If so, describe the type of waste and anticipated volume of discharge.
No

b. Ground:

1) Will ground water be withdrawn, or will water be discharged to ground water? Give general description, purpose, and approximate quantities, if known.

Approximately 90,850 liters of water in the water-fillable shielding door for Tunnel No. 1 will be discharged via pipeline to the 200 Area Treated Effluent Disposal Facility and treated to acceptable contaminant levels. There are no other sources of water associated with the operation of the storage tunnels.

2) Describe waste materials that will be discharged into the ground from septic waste tanks or other sources, if any (for example: domestic sewage; industrial, containing the following chemicals...; agricultural; etc.). Describe the general size of the system, the number of such systems, the number of houses to be served (if applicable), or the number of animals or humans the system(s) are expected to serve.

None.

c. Water Run-off (including storm water):

1) Describe the source of run-off (including storm water) and methods of collection and disposal, if any (include quantities, if known). Where wi11 this water flow? Will this water flow into other waters? If so, describe.

The Hanford Site receives 15 to 20 centimeters of precipitation annually. 
SEPA Environmental CheckTist PUREX Storage Tunnels

Page 9 of 23

TO BE COMPLETED BY APPLICANT

EVALUATIONS FOR

AGENCY USE ONLY

Storm water run-off is diverted away from the storage area of the PUREX Storage

Tunnels by the sloped soil overburden and eventually infiltrates into the porous soils in the general vicinity.

2) Could waste materials enter ground or surface waters? If so, generally describe.

No.

d. Proposed measures to reduce or control surface, ground, and run-off water impacts, if any:

The storage area of each tunnel has a roof and wall system designed to prevent infiltration of run-off into the PUREX Storage Tunnels. The external surfaces of the roof and the wal1 timbers of Tunnel Number 1 are covered with 40.8-kilogram-mineral-surface roofing material. For Tunnel Number 2, the semicircular shaped, bituminous-coated steel roof construction provides infiltration protection. In addition, the 2.4-meter soil overburden and surrounding surface area have been contoured to alleviate ponding and to divert surface water away from the PUREX Storage Tunnels.

Other potential impacts include the water contained in the water-fillable doors (Tunnel. Number 1 door is presently filled; Tunnel Number 2 door is presently empty and there are no $p l a n s$ to fill the door) and nonregulated liquid heels remaining in some of the equipment stored in the tunnels. To mitigate spilis of the equipment heels during transport, catch pans are attached on the railcars under the equipment where such leakage could occur. A sump with a drain is present beneath each water-fillable door to prevent water from overfilling and/or leakage from entering the tunnel storage area. As part of PUREX Facility deactivation, any water remaining in the doors will be removed and the drains will be capped. 


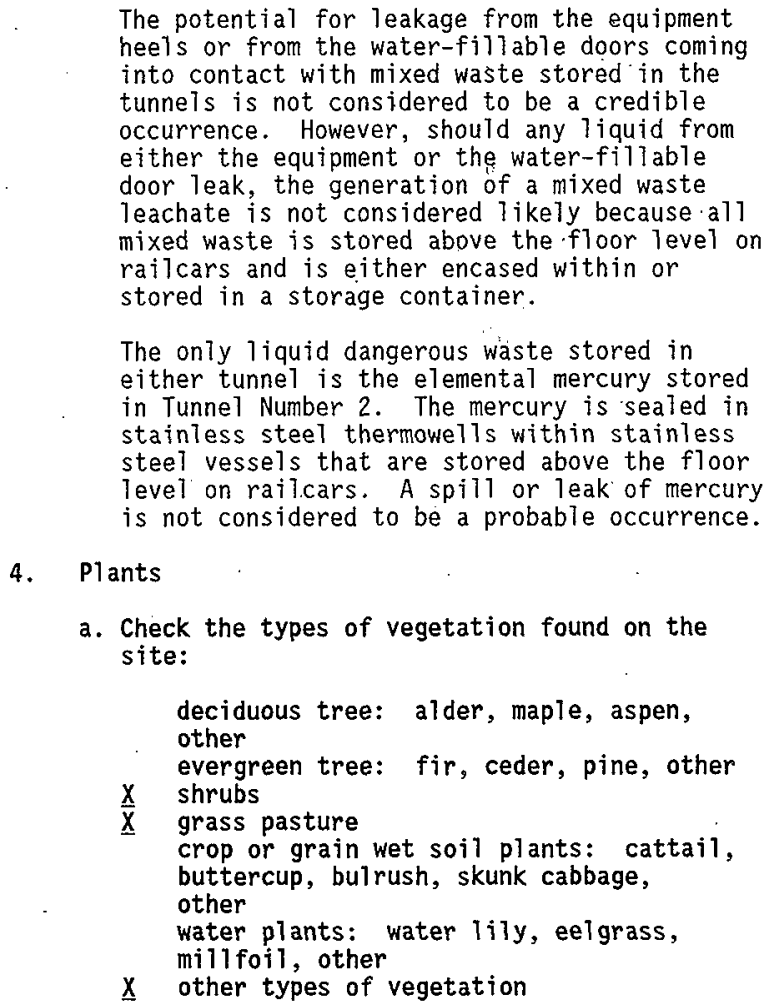

4. Plants

The potential for leakage from the equipment heels or from the water-fillable doors coming into contact with mixed waste stored in the tunnels is not considered to be a credible occurrence. However, should any liquid from either the equipment or the water-fillable door leak, the generation of a mixed waste leachate is not considered likely because all mixed waste is stored above the floor level on railcars and is either encased within or stored in a storage container.

The onty liquid dangerous waste stored in either tunnel is the elemental mercury stored in Tunnel Number 2 . The mercury is sealed in stainless steel thermowells within stainless steel vessels that are stored above the floor level on railcars. A spill or leak of mercury is not considered to be a probable occurrence.

a. Check the types of vegetation found on the site:

$$
\text { deciduous tree: alder, maple, aspen, }
$$
other evergreen tree: fir, ceder, pine, other

$X$ shrubs

X grass pasture crop or grain wet soil plants: cattail, buttercup, bulrush, skunk cabbage, other water plants: water lily, eelgrass, millfoil, other

$\mathrm{X}$ other types of vegetation

Natural vegetation has been allowed to cover the tunnel mounds to minimize both wind and water erosion. The vegetation consists of sagebrush, grasses, and other common central Washington desert plant species.

b. What kind and amount of vegetation will be removed or altered?

The original vegetation at the site was disturbed during construction, although this 
TO BE COMPLETED BY APPLICANT

natural vegetation has regrown to cover the site.

c. List threatened or endangered species known to be on or near the site.

None. However, additional information

concerning endangered and threatened plants on the Hanford Site can be found in the environmental documents referred to in the answer to Checkl ist Question A.8.

d. Proposed landscaping, use of native plants, or other measures to preserve or enhance vegetation on the site, if any:

As mentioned previously, native plants have been allowed to cover the site of the PUREX Storage Tunnels. The site can be revegetated if disturbed.

\section{Animals}

a. Circle any birds and animals which have been observed on or near the site or are known to be on or near the site:

birds: hawk, heron, eagle, songbirds, other mammals: deer, bear, elk, beaver, other fish: bass, salmon, trout, herring, shellfish, other

A variety of insects, birds, and small mammals common to the Hanford Site, including pigeons, songbirds, rodents, and hares, have been observed at or near the PUREX storage Tunnels site. Larger mammals commonly seen in the vicinity include deer and coyote. Additional information on birds and animals on the Hanford Site can be found in the environmental documents referred to in the answer to Checklist Question A.8.

b. List any threatened or endangered species known to be on or near the site.

None. However, additional information concerning endangered and threatened species on the Hanford Site can be found in the 
6. Energy and Natura1 Resources

environmental documents referred to in the answer to Checklist Question A.8.

c. Is the site part of a migration route?

If so, explain.

The site is located within the region-wide Pacific flyway for waterfowl.

d. Proposed measures to preserve or enhance wild 1 ife, if any:

The PUREX Storage Tunnels are covered with a minimum of 2.4 meters of soil to isolate their contents from local fauna.

a. What kinds of energy (electric, natural gas, oi1, wood stove, solar) will be used to meet the completed project's energy needs? Describe whether it will be used for heating, manufacturing, etc.

Currentiy, electricity is used to power the PUREX Storage Tunnels water-fillable shielding doors and the Tunnel Number 2 ventilation system. The locomotive normally used to position each loaded rajlcar into a storage tunnel is battery operated. If necessary, diesel fuel, gasoline, and 0il will be used to operate equipment during final disposition.

b. Would your project affect the potential use of solar energy by adjacent properties? If so, generally describe.

No.

c. What kinds of energy conservation features are included in the plans of this proposal? List other proposed measures to reduce or control energy impacts, if any:

Does not apply. 
17. Environmental Health.

2

3 a. Are there any environmental health hazards, including exposure to toxic chemicals, risk of fire and explosion, spill, or hazardous waste, that could occur as a result of this proposal? If so, describe.

Dangerous waste that could be stored in the PUREX Storage Tunnels includes elemental mercury, lead, silver, silver salts, cadmium, chromium, barium, and selenium. None of this waste presents a risk to personnel, the public, or the environment.

The silver nitrate fraction of the mixture of silver salts exhibits the characteristic of ignitability as defined in WAC 173-303-095(5). However, this material is contained within stainless steel vessels, and ignition of the material is not considered to be a credible event. The risk of fire associated with the storage of silver nitrate is considered to be extremely low.

1) Describe special emergency services that might be required.

Hanford Patrol, fire response, and ambulance services are on call 24-hours a day in the event of an onsite emergency.

2) Proposed measures to reduce or control environmental health hazards, if any:

The PUREX Storage Tunnels are located approximately 37 kilometers from Richland, Washington, the nearest population center. This isolation, coupled with multiple security barriers, prevents unauthorized access to the PUREX Storage Tunnels. Approval for each entry is evaluated on a case-by-case basis. Access to the PUREX Storage Tunnels by employees is restricted only to personnel having proper training and management approval. 
The management practice of keeping personnel radiological exposures to as low as reasonably achievable (ALARA) levels is adhered to strictly. Personnel entering the PUREX Storage Tunnels are required to wear special protective clothing and respirators. Operations at the PUREX Storage Tunnels are carefully managed to ensure that all activities are conducted in a safe and environmentally sound manner.

b. Noise

1) What type of noise exists in the area which may affect your project (for example: traffic, equipment, operation, other)?

None.

2) What types and levels of noise would be created by or associated with the project on a short-term or a long-term basis (for example: traffic, construction, operation, other\}? Indicate what hours noise would come from the site.

Operation of the PUREX Storage Tunnels requires infrequent use of a battery-powered locomotive to push railcars into position. This operation does not generate excessive noise.

3) Proposed measures to reduce or control noise impacts, if any:

Does not apply.

8. Land and Shoreline Use

a. What is the current use of the site and adjacent properties?

The PUREX Storage Tunnels are located within the 200 East Area of the Hanford Site. The Hanford Site is owned by the U.S. Government and is currentiy undergoing environmental 
SEPA EnvironmentaT Checklist

PUREX Storage Tunnels

Page 15 of 23

TO BE COMPLETED BY APPLICANT

EVALUATIONS FOR AGENCY USE ONLY

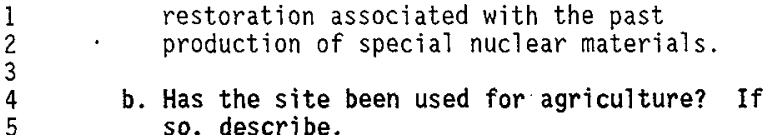

No portion of the Hanford Site, including the. site of the PUREX Storage Tunnels, has been used for agricultural purposes since.1943.

\section{c. Describe any structures on the site.}

Construction details of the PUREX Storage Tunnels are provided in Chapter.2.0 of the accompanying RCRA Part B Permit Application documentation. Each storage tunnel consists of three areas: a water-fillable door, a storage area, and a vent shaft. The water-fillable doors are approximately 7.5 meters high, 6.6 meters wide, and 2.1 meters thick. Electric hoists for raising (opening) and lowering (closing) the doors are located on top of the concrete door enclosures.

TunneT Number 1 is constructed primarily of treated Douglas Fir timbers, covered with a 40.8-kilogram-minera]-surface roofing material. The 2.4 meters of earth fill placed over the roof timbers serve as radiation shielding. The floor consists of a railroad track laid on a gravel bed that slopes on a 1.0 percent grade southward.

A combination of steel and reinforced concrete was used to construct the storage area of Tunnel Number 2. Tunnel Number 2 has a 10.4-meter diameter, nearly semicircular, steel roof supported by internal I-beam wales attached to external, reinforced concrete arches. The structure is supported on reinforced concrete-grade beams that run the full length of the tunnel. The interior and exterior surfaces of the steel roof are coated with a bituminous coating compound to inhibit corrosion, and the entire storage area is covered with 2.4 meters of earth fill that serves as radiation shielding. The floor 
consists of a railroad track laid on a gravel bed that siopes on a one-tenth of 1 percent grade southward.

A vent shaft is located at the south end of each tunnel. The shafts are constructed of reinforced concrete. Each shaft extends approximate1y 0.3 meter above grade and is capped with a single high-efficiency particulate air filter, a 153-cubic-meter per minute exhaust fan, and a 6.1-meter-ta11 exhaust stack. The exhaust fan on Tunnel Number 1 has been deactivated, and the fan on Tunnel Number 2 has been damped to provide only about 100-cubic meters per minute exhaust flow.

d. Will any structures be demolished? If so, What?

No structures will be demolished as a part of this proposal.

e. What is the current zoning classification of the site?

The Hanford Site is zoned by Benton County as an Unclassified Use (U) district.

$f$. What is the current comprehensive plan designation of the site?

The 1985 Benton County Comprehensive Land Use P7an designates the Hanford Site as the

"Hanford Reservation". Under this designation, Tand on the Hanford Site may be used for "activities nuclear in nature". Non-nuclear activities are authorized "if and when DOE approval for such activities is obtained".

g. If applicable, what is the current shoreline master program designation of the site?

Does not apply. 
h. Has any part of the site been classified as an "environmentally sensitive" area? If so, specify.

No.

i. Approximately how many people would reside or work in the completed project?

None.

j. Approximately how many people would the completed project displace?

None.

k. Proposed measures to avoid or reduce displacement impacts, if any:

Does not apply.

1. Proposed measures to ensure the proposal is compatible with existing and projected land uses and plans, if any:

Does not apply. (Refer to answer to Checklist Question B.8.f.)

9. Housing

a. Approximately how many units would be provided, if any?. Indicate whether high-, middle-, or low-income housing.

None.

b. Approximately how many units, if any, would be el iminated? Indicate whether high-, middle-, or low-income housing.

None.

c. Proposed measures to reduce or control housing impacts, if any:

Does not apply. 


\section{Aesthetics}

a. What is the tallest height of any proposed structure(s), not including antennas; what is the principal exterior building material(s) proposed?

The tallest aboveground structures associated with the PUREX Storage Tunnels are the existing water-fillable doors, which are approximately 7.5 meters high. Electric hojsts for raising (opening) and lowering (closing) the doors and steel handrails are located on top of the concrete door enclosures.

b. What views in the immediate vicinity would be altered or obstructed?

None.

c. Proposed measures to reduce or control aesthetic impacts, if any:

Does not apply.

11. Light and GTare

a. What type of light or glare will the proposal produce? What time of day would it mainly occur?

None.

b. Could light or glare from the finished project be a safety hazard or interfere with views?

No.

c. What existing off-site sources of light or glare may affect your proposal?

None.

d. Proposed measures to reduce or control light and glare impacts, if any:

Does not apply. 


\section{Recreation}

a. What designated and informal recreational opportunities are in the immediate vicinity?

None.

b. Would the proposed project displace any existing recreational uses? If so, describe.

Does not apply.

c. Proposed measures to reduce or control impacts on recreation, including recreation opportunities to be provided by the project or applicant, if any?

Does not apply.

13. Historic and Cultural Preservation

a. Are there any places or objects listed on, or proposed for, national, state, or local preservation registers known to be on or next to the site? If so, generally describe. No places or objects listed on, or proposed for, national, state, or local preservation registers are known to be on or next to the site.

The PUREX Storage Tunnels are located in an area that was disturbed extensively during construction of the PUREX Facility. Additional information on the Hanford Site environment can be found in the environmental documents referred to in the answer to Checklist Question A.8.

b. Generaliy describe any landmarks or evidence of historic, archaeological, scientific, or cultural importance known to be on or next to the site.

There are no known archaeological, historical, or native American religious sites at or next to the PUREX Storage Tunnels. Additional information on the Hanford Site environment can be found in the environmental documents 
referred to in the answer to Checklist

Question A.8.

c. Proposed measures to reduce or control impacts, if any:

As appropriate, detailed cultural resource reviews will provide the vehicle for necessary approvals required under the National Historic Preservation Act.

14. Transportation

a. Identify public streets and highways serving the site, and describe proposed access to the existing street system. Show on site plans, if any.

Does not apply.

b. Is site currently served by public transit? If not, what is the approximate distance to the nearest transit stop?

The site is not publicly accessible, and, therefore, is not served by public transportation.

c. How many parking spaces would the completed project have? How many would the project el iminate?

None.

d. Will the proposal require any new roads or streets, or improvements to existing roads or streets, not including driveways? If so, generaliy describe (indicate whether public or private).

No.

e. Will the project use (or occur in the immediate vicinity of) water, rail, or air transportation? If so, generally describe.

The PUREX Storage Tunnels are an extension of the rail spur on which irradiated reactor 
fuels were delivered to the PUREX Plant for chemical reprocessing. Material to be stored in the tunnels is loaded on modified railcars that serve as transport and storage platforms. Normally, a remote-controlled, battery-powered locomotive is used to position each loaded railcar into a storage tunnel, however, other remote movers have been or could be used to position a railcar in the tunnel or to withdraw a car from the tunnel.

f. How many vehicular trips per day would be generated by the completed project? If known, indicate when peak volumes would occur.

None.

g. Proposed measures to reduce or control

transportation impacts, if any:

Does not apply.

\section{Public Services}

a. Would the project result in an increased need for public services (for example: fire protection, police protection, health care, schools, other)? If so, generally describe.

No.

b. Proposed measures to reduce or control direct impacts on public services, if any:

Does not apply.

16. Utilities

a. List utilities currently available at the site (electricity, natural gas, water, refuse service, telephone, sanitary sewer, septic system, other):

There are no electrical utilities, water supply systems, drains, fire detection systems, or communications systems provided inside the storage area of the PUREX Storage Tunnels. All electricity, water supply lines, 
and drain lines used in the operation of the PUREX Storage Tunnels are external.

Electricity, communications systems, and other utilities will be available within the PUREX Plant until deactivation is complete. In the event the PUREX Storage Tunnels receive waste after PUREX Plant deactivation, necessary utilities will have to be brought in from outside the PUREX Facility.

b. Describe the utilities that are proposed for the project, the utility providing the service, and the general construction activities on the site or in the immediate vicinity which might be needed.

No additional utilities are proposed. 


\section{SIGNATURES}

The above answers are true and complete to the best of my knowledge. We understand that the lead agency is relying on them to make its decision.

5

6

7

8

9

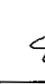

James E. Rasm

fffice of Environmental Assurance,

Permits, and Policy Division

U.S. Department of Energy

Richland Operations office

D. G. Hamrick, Director PUREX Transition Project

Mestinghouse Hanford Company
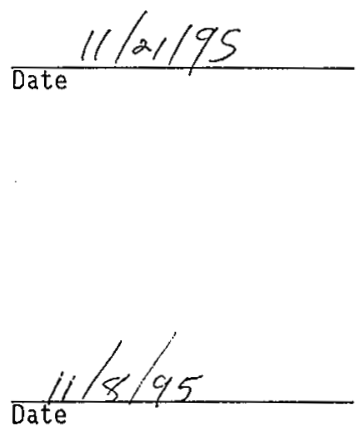


\section{HIS PAGE INTENTTONALLY L LEFT BLANK}

